\title{
Life-Cycle Assessment of Urine Diversion and Conversion to Fertilizer Products at the City Scale
}

by

Stephen Hilton

\author{
A thesis submitted \\ In partial fulfillment of the requirements \\ For the degree of Master of Science \\ (Environment and Sustainability) \\ In the University of Michigan
}

August 2020

Thesis Committee:

Professor- Gregory Keoleian, Chair

Professor Glen Daigger 


\section{ACKNOWLEDGMENTS}

I would like to thank Dr. Greg Keoleian for his guidance, motivation, and for always making time to help me. I appreciate him assisting me with this research, the degree, and the steps after. I also appreciate Dr. Glen T. Daigger and Bowen Zhou for their guidance on wastewater systems and many contributions throughout the project. I would like to thank Dr. Nancy Love, Dr. William Tarpeh, the members of the UM Urine Diversion research project, and the Rich Earth Institute for their expertise on urine diversion, their inspiring research, and frequent support. I would also like to thank Dr. Steven Skerlos for his assistance with earlier manuscripts, and Dr. Geoff Lewis for his frequent direction on Life Cycle Assessment research methods. Lastly, I would like to thank the many people who supported me throughout this project.

This research was supported by the U.S. National Science Foundation under award number INFEWS 1639244 and the Water Research Foundation under project number STARNa1R14/4899 to the University of Michigan. 


\section{PREFACE}

Separate collection of urine to recover nitrogen and phosphorus has been advocated to enhance the sustainability of water management and food production. Urine could provide a renewable source of nitrogen and phosphorus, which are currently extracted from nonrenewable resources. Urine diversion also has the potential to prevent nutrients from entering water bodies and to reduce the amount of energy and chemicals needed to treat wastewater. However, urine diversion would require systems to collect urine, produce urine-derived fertilizers, and to ship them, all of which have their own environmental impacts. This thesis explores the greenhouse gas emissions, cumulative energy demand, freshwater use, eutrophication potential, and acidification potential of systems that recover urine compared to those that do not. It evaluates the importance of location-specific factors by focusing on three locations, and then by conducting further sensitivity analysis. This work has been submitted to the journal Environmental Science \& Technology (currently in review). 


\section{TABLE OF CONTENTS}

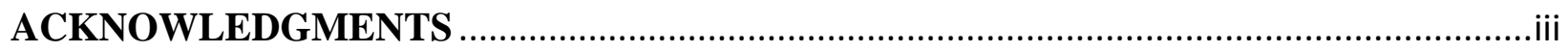

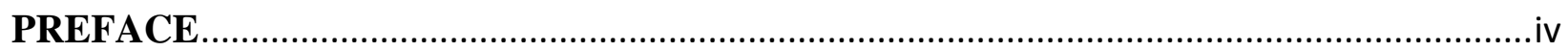

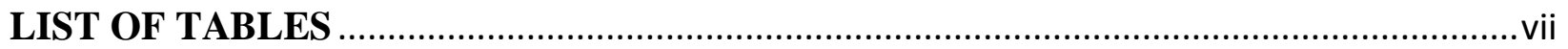

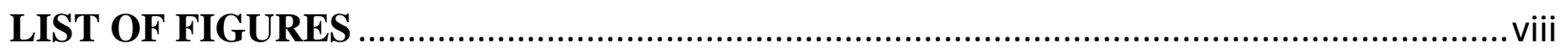

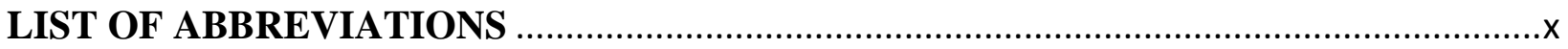

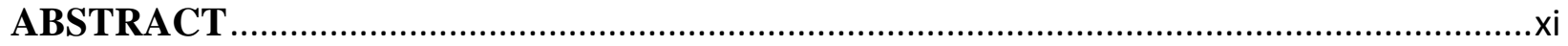

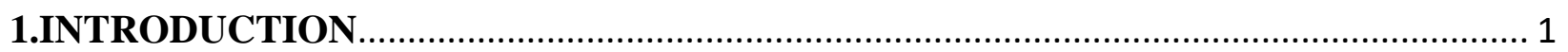

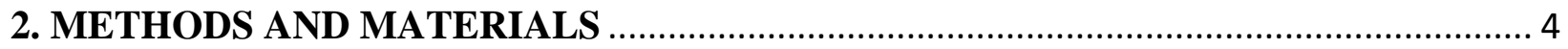

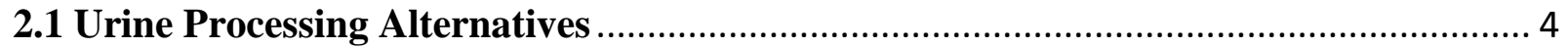

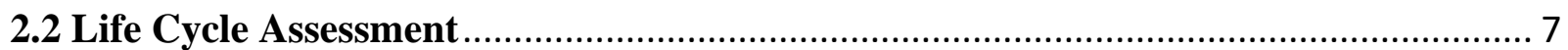

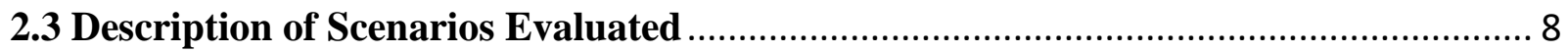

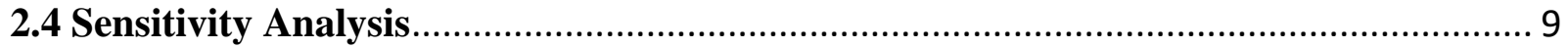

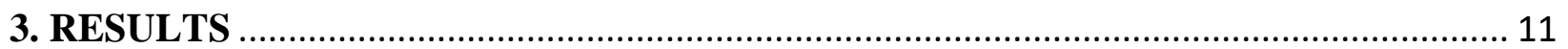

3.1 Life Cycle Impacts Across Scenarios................................................................. 11

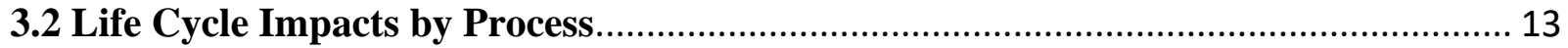

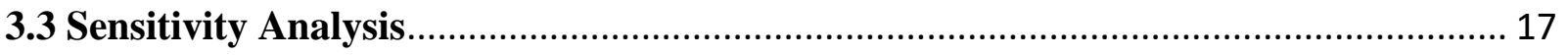

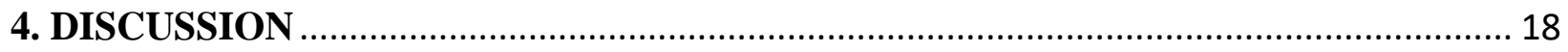

APPENDIX A: SYSTEM SCOPE AND BOUNDARY .................................................... 22

APPENDIX B: WASTEWATER TREATMENT MODELING ...................................... 28

B1 Influent, Preliminary and Primary Treatment................................................... 28

B2 Secondary Treatment and Nutrient Removal ...................................................... 29

APPENDIX C: LIFE CYCLE ASSESSMENT DATA ................................................. 42

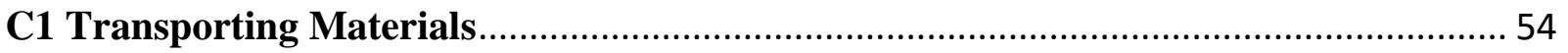

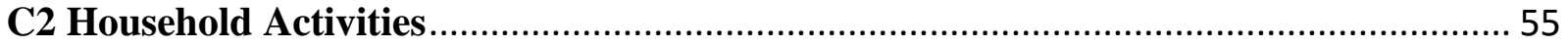

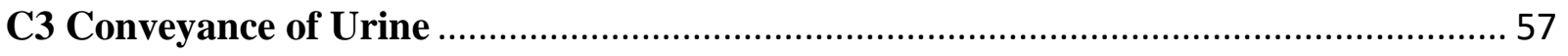

C4 Urine Derived Fertilizer Production................................................................ 57

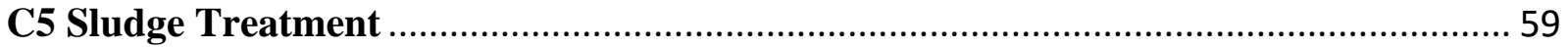

C6 Data Sources for Unit Processes.......................................................................... 61

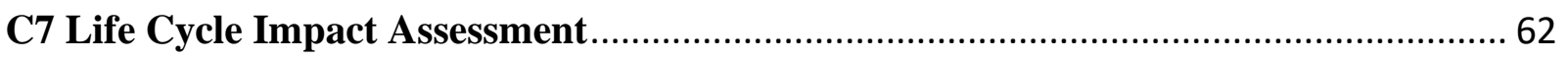




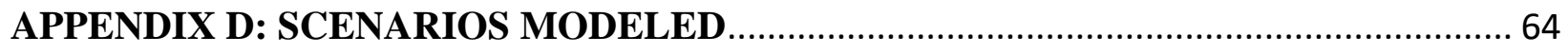

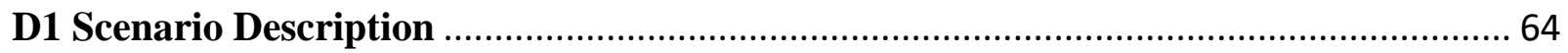

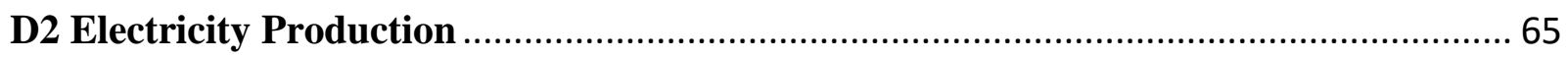

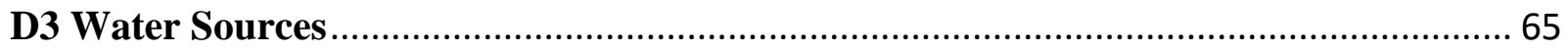

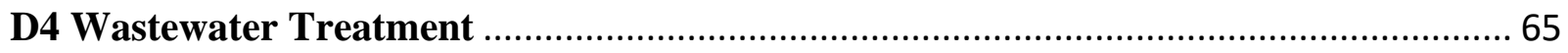

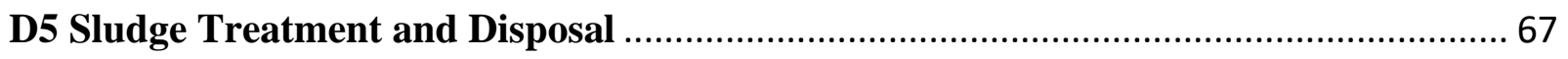

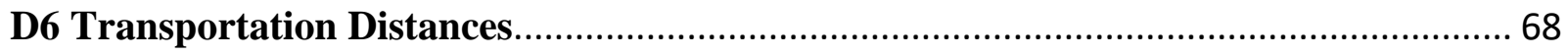

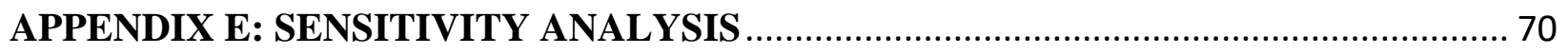

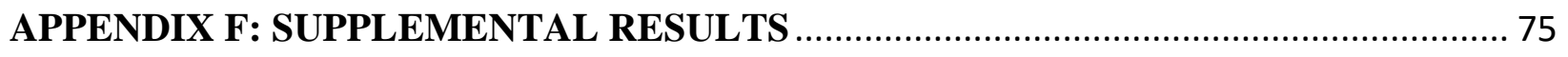

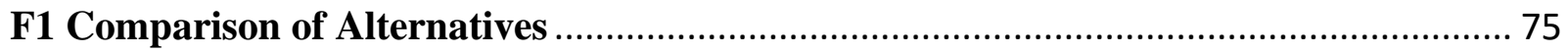

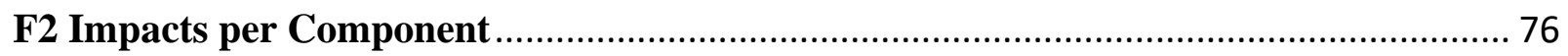

APPENDIX G: RESULTS OF THE SENSITIVITY ANALYSIS .................................... 87 


\section{LIST OF TABLES}

Table 1. Important parameters to model urine collection and fertilizer production. ................... 7

Table 2. Comparison of Three Scenarios........................................................................... 9

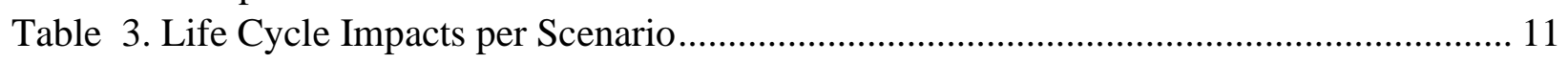

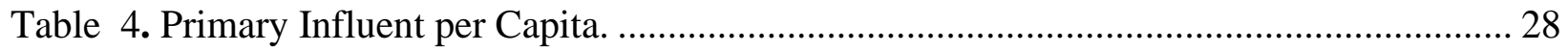

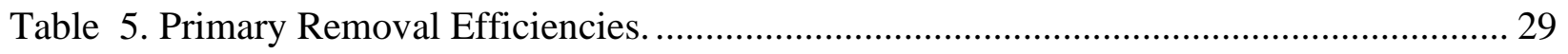

Table 6. Wastewater Conversion Factors. ............................................................................ 30

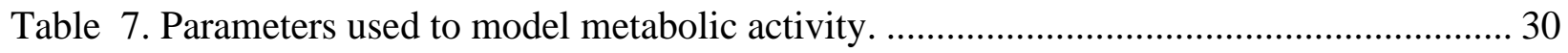

Table 8. Parameters used to model metabolic activity. ......................................................... 31

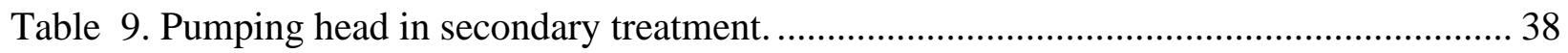

Table 10. List of inputs used to model the life cycle assessment. ........................................... 42

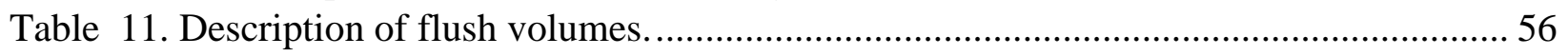

Table 12. List of data sources used to quantify environmental impacts.................................. 61

Table 13. Environmental impacts of electricity production.................................................. 65

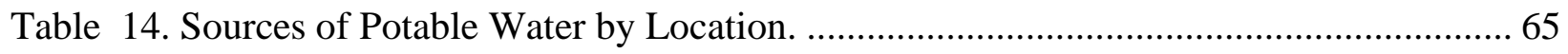

Table 15. Effluent Wastewater Standard for input in Each Location.......................................6 66

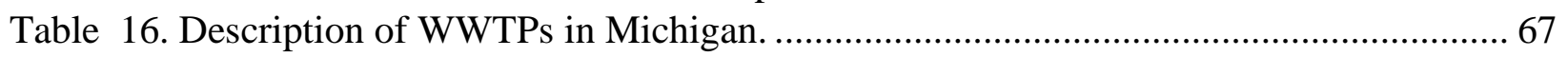

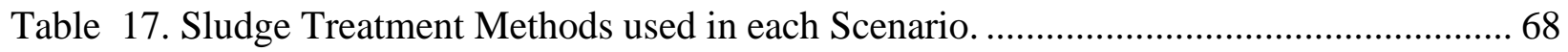

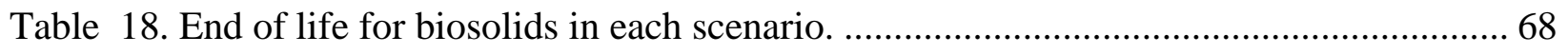

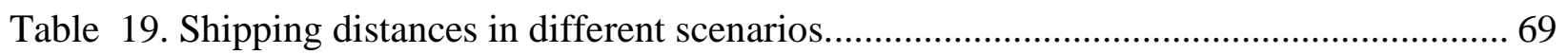

Table 20. List of distributions for parameters in the Monte Carlo analysis. ........................... 71

Table 21. Urine Concentration Scenarios with lower GWP.................................................. 90

Table 22. Struvite and Ammonium Sulfate Scenarios with lower GWP............................... 90 


\section{LIST OF FIGURES}

Figure $1 \mathrm{a}$ a-c. System Diagram for each alternative............................................................ 5

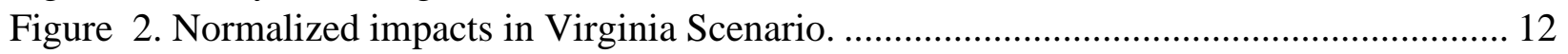

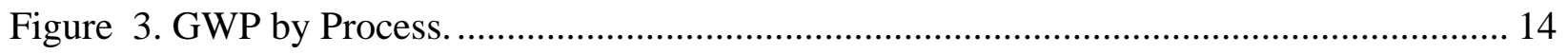

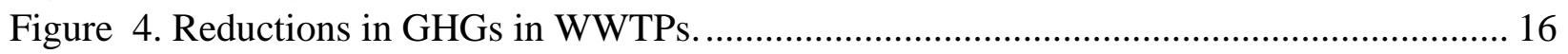

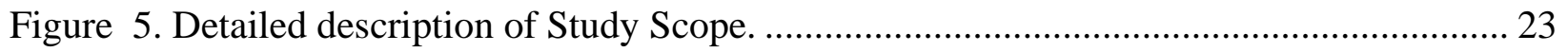

Figure 6. Depiction of simulations ran in sensitivity analysis................................................. 70

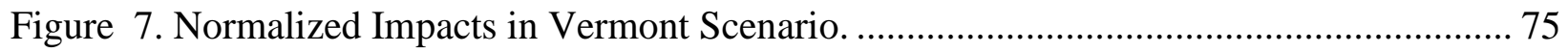

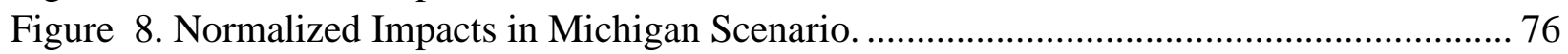

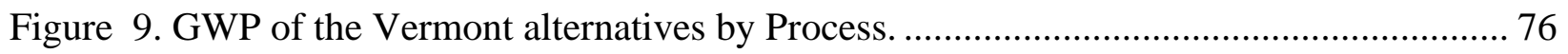

Figure 10. CED of the Vermont alternatives by Process.......................................................... 77

Figure 11. Freshwater use of the Vermont alternatives by Process............................................. 77

Figure 12. Eutrophication potential of the Vermont alternatives by Process. .............................. 78

Figure 13. Acidification potential of the Vermont alternatives by Process................................... 78

Figure 14. GWP of the Michigan alternatives by Process........................................................ 79

Figure 15. CED of the Michigan alternatives by Process................................................... 79

Figure 16. Freshwater use of the Michigan alternatives by Process............................................ 80

Figure 17. Eutrophication potential of the Michigan alternatives by Process.............................. 81

Figure 18. Acidification potential of the Virginia alternatives by Process................................. 82

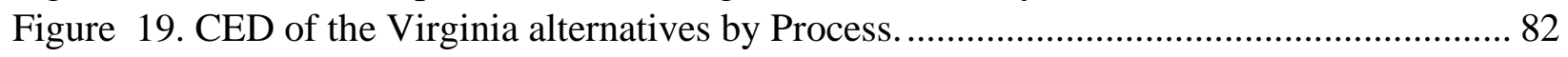

Figure 20. Freshwater use of the Virginia alternatives by Process............................................. 83

Figure 21. Eutrophication potential of the Virginia alternatives by Process............................... 83

Figure 22. Acidification potential of the Virginia alternatives by Process................................... 84

Figure 23. Comparison of WWTP Modeling Methods. ................................................................ 84

Figure 24. Differences in GHGs from Urine Concentration in sensitivity analysis..................... 87

Figure 25. Differences in GHGs from Struvite and Ammonium Sulfate in sensitivity analysis. 87

Figure 26. Differences in APs from Urine Concentration in sensitivity analysis......................... 88

Figure 27. Differences in APs from Struvite and Ammonium Sulfate in sensitivity analysis. ... 88 Figure 28. GWP Comparison of Urine Concentration and Struvite and Ammonium Sulfate in

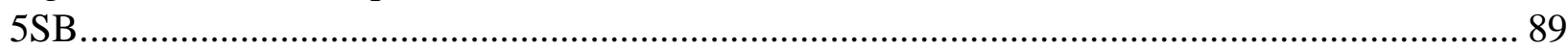

Figure 29. GWP Comparison of Urine Concentration and Struvite and Ammonium Sulfate in SAB. 


\section{LIST OF ABBREVIATIONS}

$\begin{array}{ll}\text { LCA } & \text { Life Cycle Assessment } \\ \text { p.e. } & \text { Person Equivalent } \\ \text { USLCI } & \text { United States Life Cycle Inventory } \\ \text { GREET } & \text { The Greenhouse Gases, Regulated Emissions, and Energy Use in } \\ & \text { Transportation Model } \\ \text { TRACI } & \text { Tool for Reduction and Assessment of Chemicals and Other } \\ & \text { Environmental Impacts } \\ \text { GWP } & \text { Global Warming Potential (100 year) } \\ \text { CED } & \text { Cumulative Energy Demand } \\ \text { EP } & \text { Eutrophication Potential } \\ \text { AP } & \text { Acidification Potential } \\ \text { N } & \text { Nitrogen } \\ \text { P } & \text { Phosphorus } \\ \text { TN } & \text { Total Nitrogen } \\ \text { A2O } & \text { Anaerobic/Anoxic/Oxic (Wastewater Treatment Process) } \\ \text { RO } & \text { Reverse Osmosis } \\ \text { COD } & \text { Chemical Oxygen Demand } \\ \text { BOD5 } & \text { 5 Day Biochemical Oxygen Demand } \\ \text { TSS } & \text { Total Suspended Solids } \\ \text { VSS } & \text { Volatile Suspended Solids } \\ \text { TKN } & \text { Total Kjeldahl Nitrogen } \\ \text { SRT } & \text { Solids Retention Time } \\ \text { OHO } & \text { Ordinary Heterotrophic Organism } \\ \text { PAO } & \text { Phosphorus-Accumulating Organism } \\ \text { MLE } & \text { Modified Ludzack-Ettinger } \\ \text { MLSS } & \text { Mixed Liquor Suspended Solids } \\ \text { RAS } & \text { Return Activated Sludge } \\ \text { MLR } & \text { Mixed Liquor Recirculation } \\ \text { WAS } & \text { Waste Activated Sludge } \\ \text { TP } & \text { Total Phosphorus } \\ \text { WWTP } & \text { Wastewater Treatment Plant } \\ \text { DA } & \text { Direct + aeration emissions } \\ \text { DAS } & \text { Direct + aeration + substrate emissoins } \\ \text { 5SB } & \text { 5-Stage Bardenpho } \\ \text { SAB } & \text { Single Aeration Basin } \\ & \end{array}$




\begin{abstract}
Urine diversion has been proposed as an approach for producing renewable fertilizers and reducing nutrient loads to wastewater treatment plants. Life cycle assessment was used to compare environmental impacts of the operations phase of urine diversion and fertilizer processing systems (via 1) a urine concentration alternative and 2) a struvite precipitation and ion exchange alternative) at a city scale to conventional systems. Scenarios in Vermont, Michigan, and Virginia were modeled, along with additional sensitivity analysis to understand the importance of key parameters, such as the electricity grid and wastewater treatment method. Both urine diversion technologies had better environmental performance than the conventional system, and led to reductions of $29-47 \%$ in greenhouse gas emissions, $26-41 \%$ in energy consumption, approximately half the freshwater consumption, and $25-64 \%$ in eutrophication, while acidification ranged between a $24 \%$ decrease to a $90 \%$ increase. In some situations wastewater treatment chemical requirements were eliminated. The environmental performance improvement was usually dependent on offsetting the production of synthetic fertilizers. This study suggests that urine diversion could be applied broadly as a strategy for both improving wastewater management and decarbonization.
\end{abstract}




\section{INTRODUCTION}

About half of the world food supply depends on synthetic fertilizers produced from nonrenewable resources ${ }^{1}$. Phosphate rock is used to produce phosphorus fertilizers. While the extent of the resource base is contested, supply is finite, demand has increased partly due to increased meat consumption and biofuel production, and supplies are dominated by a few countries. ${ }^{2-5}$ Production of nitrogen fertilizer depends on natural gas, and is responsible for about $1.2 \%$ of world energy use and associated greenhouse gas emissions. ${ }^{6,7}$ Prices for phosphate rock and other fertilizer commodities have fluctuated as much as $800 \%$ in recent years, which has led to food riots in many countries. ${ }^{3,4,8}$ Given the impacts and resource constraints of conventional fertilizers, renewable and reliable alternatives are needed.

Food consumption by humans is the principal source of these vital nutrients in domestic wastewater, and significant resources are invested to remove them to protect the aquatic environment. Water and wastewater systems consume about 3-4\% of the total electricity in the United States, with nutrient removal often being one of the most energy intensive processes. ${ }^{9,10}$ Some propose separately collecting urine and using it to produce fertilizer. ${ }^{11,12}$ Although it comprises less than $1 \%$ of wastewater volume, urine contains approximately $50 \%$ of the phosphorus and $80 \%$ of the nitrogen contained in domestic wastewater. ${ }^{13-15}$ As utilities increasingly focus on sustainability, large-scale urine diversion has the potential to improve regional wastewater management, recover essential resources and reduce energy consumed in processes such as aeration. ${ }^{11,16-19}$ 
Compared to synthetic fertilizers, urine-derived fertilizers recover important nutrients, can be as effective at stimulating plant growth, and contain lower levels of heavy metals. ${ }^{19-26}$ However, processing fertilizers from urine will have environmental impacts. ${ }^{15}$ Collecting and transporting urine will require new infrastructure systems, such as pressurized pipe networks or truck collection.

Use of acetic acid or other chemicals may be needed to prevent the spontaneous release of ammonia gas and formation of precipitates that clog piping infrastructure. ${ }^{15,27-29}$ Urine concentration, through processes such as reverse osmosis, freeze thaw, or distillation, may be required to make nutrient concentrations in urine, which are much lower than synthetic fertilizer, high enough for efficient agricultural application. ${ }^{15,30-34}$ Alternatively, nutrients may be concentrated through removal processes such as struvite precipitation, ammonia capture via ion exchange, or urea adsorption. ${ }^{15,20,35-41}$ Additional treatment to deactivate pathogens and remove pharmaceuticals found in urine may also be needed.

Life Cycle Assessment (LCA) is well suited to compare the environmental performance of urine diverting systems to conventional systems, determine environmental hotspots, and highlight trade-offs and opportunities for system improvement. ${ }^{42,43}$ LCA has been used to compare a range of wastewater treatment alternatives, ${ }^{44-47}$ and in most cases has indicated that urine diversion has lower environmental impacts than conventional systems . ${ }^{13,14,48-51}$ However, these studies have focused on small scale systems, have evaluated only a few locations and urine-derived fertilizers, and simplified how diverting urine will affect wastewater treatment plants. These studies measure changes to wastewater through volume reduction or a static offset for denitrification, which may not capture significant changes to wastewater treatment as nutrient ratios change, or how urine diversion could change treatment configurations..$^{48,49,52-54}$ 
This study expands upon previous research by evaluating the environmental impacts of urine diversion and conversion to fertilizer relative to conventional alternatives in large and diverse settings, and by a more detailed assessment of how this will affect wastewater treatment. This conventional alternative manages urine through the wastewater system and produces and transports equivalent amounts of nutrients in the form of synthetic fertilizer. The relative differences between these two different approaches are quantified. Wastewater treatment is modeled in detail to better account for the ramifications of urine diversion. Three distinct locations, namely the States of Vermont, Michigan, and Virginia (referred to subsequently as scenarios) are considered to explore how important parameters such as population, extent of nutrient removal at wastewater treatment plants, electricity grid fuel mix and the amount of urine-derived fertilizer produced influence the environmental performance. Sensitivity analysis is conducted using Monte Carlo in order to further evaluate these parameters and the uncertainty of many others. 


\section{METHODS AND MATERIALS \\ 2.1 Urine Processing Alternatives}

Two distinct urine-derived fertilizer alternatives were evaluated to represent the range of products that can be produced. They consist of (1) concentrated urine, where organics such as pharmaceuticals are removed from diverted urine through activated carbon and urine is subsequently concentrated by reverse osmosis (RO) and then heat pasteurized, and (2) struvite and ammonium sulfate, where urine is processed to produce struvite through precipitation and ammonium sulfate through ion exchange. Use of urine-derived fertilizer products are compared to commercial fertilizers. For the urine-derived fertilizer alternatives it was assumed that 70 percent of urine in each of the three scenarios considered was diverted for fertilizer production. This was done to simulate large-scale collection within these locations but to allow for some inefficiency in collection. As shown in Figure 1, production and distribution of flushwater, collection of wastewater (including separated urine), production and transportation of fertilizers, and wastewater treatment were included in the scope of the study to capture system-wide differences. 


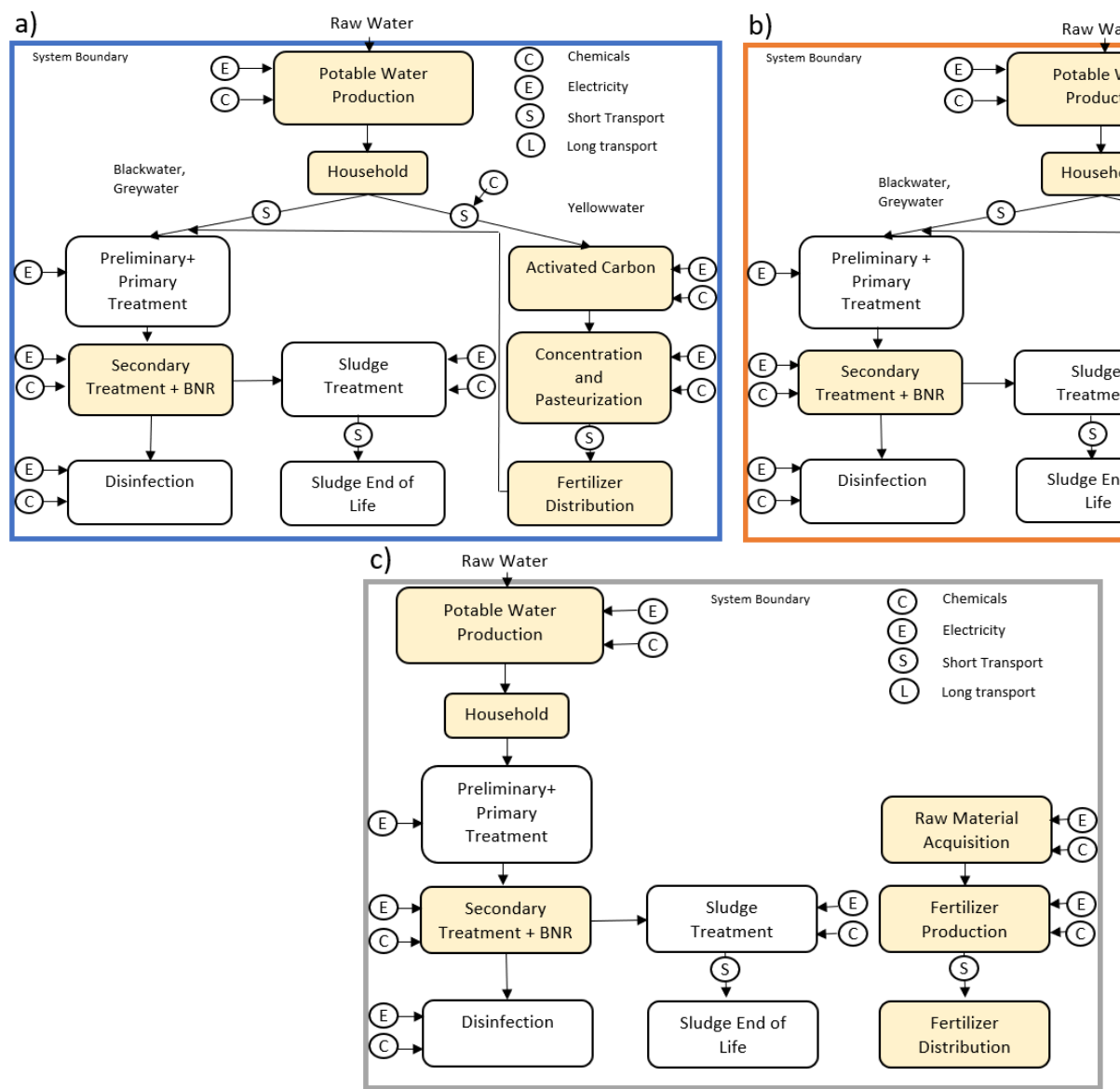

Figure 1 a-c. System Diagram for each alternative.

a) The urine concentration alternative, $b$ ) the struvite and ammonium sulfate alternative, $c$ ) the conventional system. Yellow boxes indicate that a process is either unique to that alternative, or that urine diversion significantly affects its environmental impact.

The inputs to treat and distribute flush water were determined using the ratio of surface and groundwater treated in each location, ${ }^{55}$ and literature data for both types of treatment. ${ }^{48,56,65-}$ ${ }^{67,57-64}$ When urine was diverted, urine diversion toilet flush volumes were used. In the conventional alternative, for people not using urine-diverting toilets, and during defecation, lowflow toilet flush volumes were used, as shown in Tables $11 \& 12$. When urine is diverted, acetic acid is added to stabilize it, followed by transportation to a fertilizer production center via a pressurized pipe system.

Magnesium oxide is added to precipitate phosphorus as struvite and the remaining ammonium from the effluent is captured through ion exchange using a resin such as Dowex Mac 
3. ${ }^{39}$ The exhausted resin is regenerated with $3 \mathrm{M}$ sulfuric acid, producing a liquid ammonium sulfate fertilizer. Additional acetic acid is needed for the concentrated urine fertilizer to consistently maintain nitrogen in the urea form. Following pharmaceutical removal using activated carbon, urine is concentrated to a fifth of its original volume using reverse osmosis with an energy recovery device (ERD) and then heat pasteurized. Chemical and energy inputs for regeneration of activated carbon ${ }^{68-72}$ and reverse osmosis membrane cleanings ${ }^{73}$ are included. Effluents from the urine-derived fertilizer production facilities are sent to the wastewater treatment plant, and the urine-derived fertilizers are trucked to a regional fertilizer distributor.

The methodology described in Hilton et al. ${ }^{74}$ is used to model wastewater treatment for all alternatives to determine electricity consumption, chemical consumption, secondary sludge production, water and air emissions. All alternatives assumed equal amounts of feces and greywater, steady state conditions, and compliance with all regulatory requirements. Processes that were equivalent in magnitude between alternatives, such as primary sludge treatment and hauling screenings to landfills, were excluded. Further details can be found in the supplemental materials, Figure S1, and Hilton et al. ${ }^{74}$

The production of urea and mono-ammonium phosphate fertilizers and transportation to the regional fertilizer distribution center was used to ensure all alternatives provided the same mass of nitrogen and phosphorus as fertilizer. These synthetic fertilizers were added in the conventional and both diversion alternatives to provide equal amounts of nitrogen and phosphorus despite differing nutrient recovery ratios. Transportation from the regional fertilizer distribution center and application at the farm were not analyzed, as previous research did not find plant uptake and runoff from urine-derived fertilizers to differ from synthetic fertilizers. ${ }^{25,75-}$ 77 


\subsection{Life Cycle Assessment}

The treatment of one person equivalent's (p.e.) wastewater for one year is the functional unit of analysis used. Treatment of all wastewater produced (including urine as appropriate) is considered because urine diversion can lead to significant reductions in the nitrogen and phosphorus of wastewater arriving at the treatment plant, and can significantly affect treatment. All alternatives provided equal masses of nitrogen and phosphorus in fertilizer. Environmental burdens of capital equipment and the end of life of wastewater and fertilizer infrastructure were excluded because the operational phase impacts are expected to dominate. ${ }^{78-81}$

Parameters used for the life cycle inventory and mass balance were obtained from literature sources and pilot scale systems, and can be found in Tables 1, 11 and 13. The United States Life Cycle Inventory (USLCI) was used for most unit processes, though Ecoinvent was used when unit processes were not available. ${ }^{82,83}$ A Life Cycle Impact Assessment was conducted using global warming potential (GWP), cumulative energy demand (CED), freshwater use ${ }^{84}$ eutrophication potential (EP), and acidification potential (AP). These categories represent key impacts for changes in energy use, chemical manufacturing, water quality, and water use that are caused by urine diversion.

Table 1. Important parameters to model urine collection and fertilizer production.

\begin{tabular}{|c|c|c|c|c|}
\hline Process & Parameter & Value & Unit & $\begin{array}{c}\text { Notes and } \\
\text { Sources }\end{array}$ \\
\hline Home/Collection & $\begin{array}{c}\text { Flushes per } \\
\text { person per } \\
\text { day }\end{array}$ & $3.8,5.14$ & /pe.day & $\begin{array}{c}\text { Urine only, } \\
\text { then total.85-90 }\end{array}$ \\
\hline $\begin{array}{c}\text { Conventional: } \\
\text { water per } \\
\text { flush }\end{array}$ & 4.84 & L/flush & $\begin{array}{c}\text { Also used for } \\
\text { feces flushes in } \\
\text { UD toilets }\end{array}$ \\
\hline
\end{tabular}




\begin{tabular}{|c|c|c|c|c|}
\hline & $\begin{array}{l}\text { Urine } \\
\text { diversion: } \\
\text { water per } \\
\text { flush }\end{array}$ & 0.165 & L/flush & $\begin{array}{l}\text { Used for urine- } \\
\text { only flushes. } \\
\text { Personal } \\
\text { conversation } \\
\text { Raye-Leonard } \\
18\end{array}$ \\
\hline & $\begin{array}{l}5 \% \text { acetic } \\
\text { acid added }\end{array}$ & $\begin{array}{c}0.033- \\
0.04\end{array}$ & $\begin{array}{l}\text { L/L urine } \\
\text { and } \\
\text { flushwater }\end{array}$ & $\begin{array}{l}\text { Struvite and } \\
\text { ammonium } \\
\text { sulfate } \\
\text { (Calculated) } \\
\text { then Urine } \\
\text { Concentration } \\
\text { (Experimentally } \\
\text { determined }{ }^{25} \text { ) }\end{array}$ \\
\hline \multirow[t]{3}{*}{$\begin{array}{l}\text { Struvite and } \\
\text { Ammonium } \\
\text { Sulfate } \\
\text { Production }\end{array}$} & $\begin{array}{l}\text { Mg:P ratio } \\
\text { for struvite }\end{array}$ & $1.5: 1$ & & $48,54,91,92$ \\
\hline & $\begin{array}{c}\text { Sulfuric acid } \\
\text { per kg N }\end{array}$ & 16.7 & liters/kg N & $\begin{array}{c}\text { 18\%. Tarpeh, } \\
\text { personal } \\
\text { conversation. }\end{array}$ \\
\hline & $\begin{array}{l}\mathrm{N} \text { and } \mathrm{P} \\
\text { recovery }\end{array}$ & 96,96 & $\%$ & $39,48,54,93,94$ \\
\hline \multirow[t]{2}{*}{$\begin{array}{c}\text { Concentrated } \\
\text { Urine } \\
\text { Production } \\
\end{array}$} & $\begin{array}{l}\text { RO electricity } \\
\text { consumption }\end{array}$ & 0.009 & $\begin{array}{l}\mathrm{kWh} / \mathrm{l} \\
\text { removed }\end{array}$ & $\begin{array}{c}\text { Noe-Hays, } \\
\text { Personal } \\
\text { Communication }\end{array}$ \\
\hline & $\begin{array}{c}\text { N \& P } \\
\text { Recovery }\end{array}$ & 95,99 & $\%$ & 95,96 \\
\hline
\end{tabular}

\subsection{Description of Scenarios Evaluated}

Three scenarios were modeled to provide an initial assessment of how location-specific factors affect the environmental merits and drawbacks of urine diversion. The Vermont scenario 
represents a smaller urban community without strict nitrogen effluent limits located in a largely rural state. The Michigan scenario was developed as a statewide average and was constructed by categorizing the range of communities in the State, the types of wastewater treatment plants found, and wastewater treatment volumes. The Virginia scenario represents a more denselypopulated urban location with strict effluent limits. Further description of these scenarios can be found in the supplemental materials, Tables 2 and 14-20, and Hilton et al. ${ }^{74}$ All alternatives were evaluated for each scenario.

Table 2. Comparison of Three Scenarios.

\begin{tabular}{|l|l|l|l|}
\hline Item & Vermont & Michigan & Virginia \\
\hline Description & $\begin{array}{l}\text { Largely rural state } \\
\text { with small to mid- } \\
\text { size communities }\end{array}$ & $\begin{array}{l}\text { Large state with } \\
\text { diverse range of } \\
\text { community sizes }\end{array}$ & $\begin{array}{l}\text { Stringent effluent } \\
\text { discharge standards }\end{array}$ \\
\hline Population Modeled & 25,000 & 150,000 & 350,000 \\
\hline $\begin{array}{l}\text { Effluent Discharge } \\
\text { Standards }\end{array}$ & Secondary, P limits & $\begin{array}{l}\text { Secondary, P, some } \\
\text { ammonia and TN } \\
\text { limits }\end{array}$ & $\begin{array}{l}\text { Advanced Secondary, } \\
\text { stringent TN and P } \\
\text { limits }\end{array}$ \\
\hline $\begin{array}{l}\text { Wastewater } \\
\text { Treatment } \\
\text { Process(es) }\end{array}$ & Single Aeration Basin & $\begin{array}{l}\text { Single Aeration } \\
\text { Basin, Nitrification, } \\
\text { A2O }\end{array}$ & 5-Stage Bardenpho \\
\hline $\begin{array}{l}\text { Typical Distance to } \\
\text { Fertilizer Distributors }\end{array}$ & 50 & 50 & 41 \\
\hline $\begin{array}{l}\text { GWP of Electricity } \\
\text { kg CO2e/kWh) }\end{array}$ & 0.107 & 0.544 & 0.450 \\
\hline
\end{tabular}

\subsection{Sensitivity Analysis}

Sensitivity analysis was conducted to evaluate the robustness of the results, test urine diversion in a broader range of contexts, and to elucidate how model parameters and key assumptions influenced the environmental performance of urine diversion. Twelve separate simulation scenarios were created. As shown in Figure S2, six of these simulation scenarios modeled the 5-Stage Bardenpho treatment plant because it had the highest level of nutrient 
removal, while six modeled the single aeration basin with phosphorus removal because it had the lowest level of nutrient removal. Three electric grids, coal, natural gas, and renewable comprised of $50 \%$ wind and $50 \%$ hydropower were considered for each wastewater treatment type. Both the urine concentration, and struvite and ammonium sulfate urine derived fertilizer alternatives were compared, given six simulations for each wastewater treatment type. Table 21 lists the distributions of each parameter used. The Excel plugin Simvoi was used to conduct a Monte Carlo analysis with 10,000 repetitions for each sensitivity scenario ${ }^{97}$. 


\section{RESULTS}

\subsection{Life Cycle Impacts Across Scenarios}

Urine diversion consistently provides improved environmental performance relative to the conventional system for each scenario for all impact categories, except AP, as shown in Table 3 . Both diversion alternatives reduced the GWP, CED, freshwater use, and EP categories from anywhere between $26 \%$ to $64 \%$. The urine concentration alternative typically led to larger improvements than the struvite and ammonium sulfate alternative. Urine concentration alternatives decreased the AP modestly compared to the conventional alternative for all scenarios (12-24\%), while struvite and ammonium sulfate alternatives increased the AP by $34 \%$ to $91 \%$ relative to the conventional alternative. Figures 2,7 , and 8 provide the relative differences in environmental performance for each alternative.

Table 3. Life Cycle Impacts per Scenario

\begin{tabular}{|c|c|c|c|c|c|c|}
\hline \multirow[t]{2}{*}{ Scenario } & Alternative & GWP & CED & $\begin{array}{l}\text { Freshwater } \\
\text { Use }\end{array}$ & $\begin{array}{l}\text { Eutrophication } \\
\text { Potential }\end{array}$ & $\begin{array}{l}\text { Acidification } \\
\text { Potential }\end{array}$ \\
\hline & & $\begin{array}{ll}\mathrm{kg} \\
\mathrm{CO}_{2} \mathrm{e}\end{array}$ & MJ & $\mathrm{m}^{3}$ & $\mathrm{~kg} \mathrm{~N} \mathrm{eq}$ & $\operatorname{kg~SO}_{x}$ eq \\
\hline \multirow[t]{3}{*}{ Vermont } & $\begin{array}{l}\text { Urine } \\
\text { Concentration }\end{array}$ & 14.6 & 297 & 7.28 & 1.19 & 0.0510 \\
\hline & $\begin{array}{l}\text { Struvite and } \\
\text { Ammonium } \\
\text { Sulfate }\end{array}$ & 19.7 & 313 & 7.37 & 1.27 & 0.111 \\
\hline & Conventional & 27.6 & 450 & 13.7 & 3.27 & 0.0581 \\
\hline \multirow[t]{3}{*}{ Michigan } & $\begin{array}{l}\text { Urine } \\
\text { Concentration }\end{array}$ & 30.1 & 441 & 7.66 & 1.44 & 0.123 \\
\hline & $\begin{array}{l}\text { Struvite and } \\
\text { Ammonium } \\
\text { Sulfate }\end{array}$ & 33.5 & 456 & 7.78 & 1.51 & 0.180 \\
\hline & Conventional & 47.9 & 616 & 15.1 & 3.58 & 0.135 \\
\hline
\end{tabular}




\begin{tabular}{|l|l|l|l|l|l|l|}
\hline Virginia & $\begin{array}{l}\text { Urine } \\
\text { Concentration }\end{array}$ & 22.9 & 376 & 6.67 & 0.295 & 0.0728 \\
\cline { 2 - 7 } & $\begin{array}{l}\text { Struvite and } \\
\text { Ammonium } \\
\text { Sulfate }\end{array}$ & 26.1 & 382 & 6.73 & 0.302 & 0.130 \\
\cline { 2 - 7 } & Conventional & 36.8 & 637 & 12.8 & 0.405 & 0.0941 \\
\hline
\end{tabular}

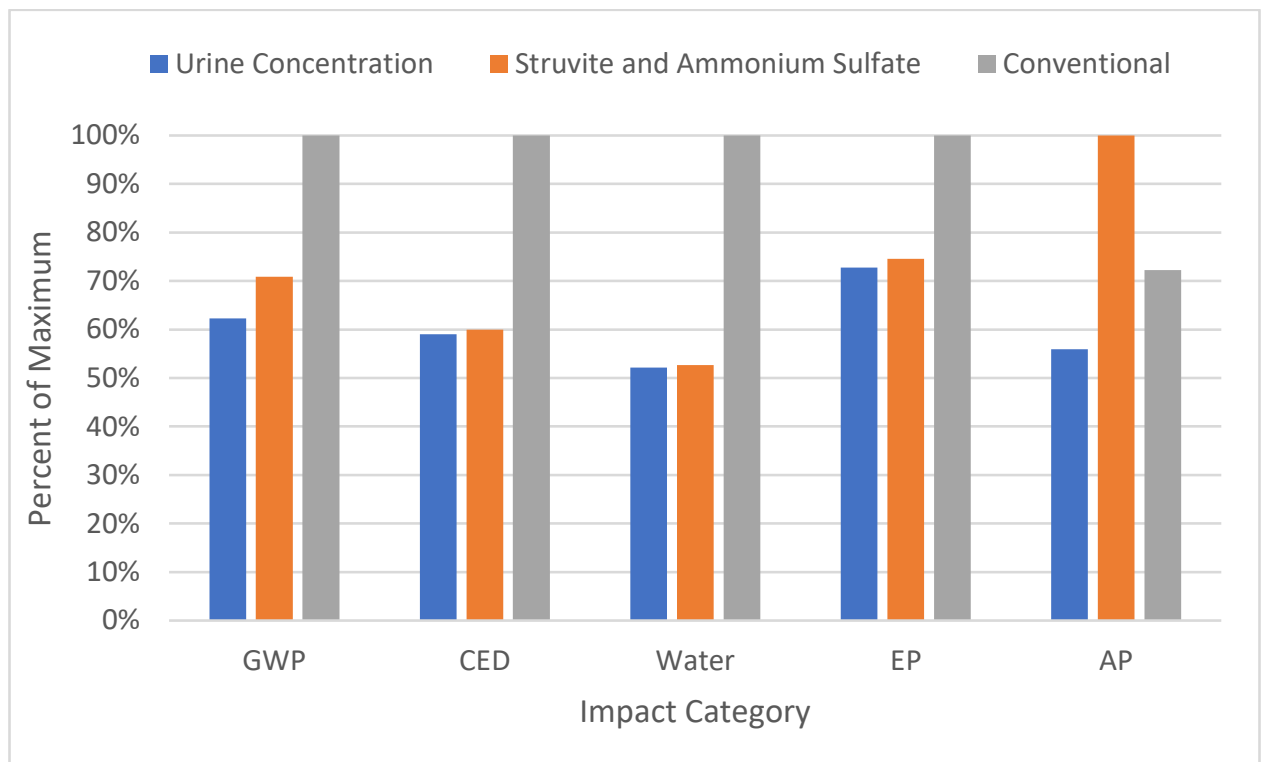

Figure 2. Normalized impacts in Virginia Scenario.

Total impacts in each alternative normalized to the maximum value in each category.

The magnitude of environmental impacts differed substantially between the three scenarios. Michigan had the highest GWP, CED, and AP impacts, while Vermont had the lowest. Much of this is because Michigan's electricity grid is comprised primarily of fossil fuels and uses natural gas to thermally dry sludge, while Vermont's electricity grid is mostly comprised of renewable energy sources. The Vermont scenario had an EP approximately four times larger than in Virginia as a result of the large differences in effluent standards. The urine diversion alternatives in states with less stringent effluent standards (Vermont and Michigan) saw the 
largest decreases in EP. The differences between the urine concentration, and struvite and ammonium sulfate alternatives were smaller for scenarios where the environmental impacts of producing electricity were larger, such as in Michigan.

\subsection{Life Cycle Impacts by Process}

Figure 3 shows the contribution of system components to greenhouse gas emissions for the Virginia scenario (see Figures S5-S18 for all impact categories and scenarios). Wastewater treatment dominated the eutrophication potential (81-99\%), was usually responsible for the largest proportion of impacts in GWP (46-56\%) and CED (35-49\%) categories, and was a major contributor to AP (16-64\%). Fertilizer production had the next largest impacts in the GWP (15$38 \%)$, CED (17-30\%), and EP (0-17\%) categories, and was a major contributor to AP (9-63\%). In Michigan and Vermont, the EP from fertilizer production was negligible relative to its contribution from wastewater effluent. Potable water production and urine collection respectively had the next largest impacts in the GWP and CED categories. The largest contributor to AP was sulfuric acid (36\%-58\% when producing ammonium sulfate) followed by acetic acid (11-17\% when producing ammonium sulfate, $20 \%-48 \%$ when concentrating urine). 


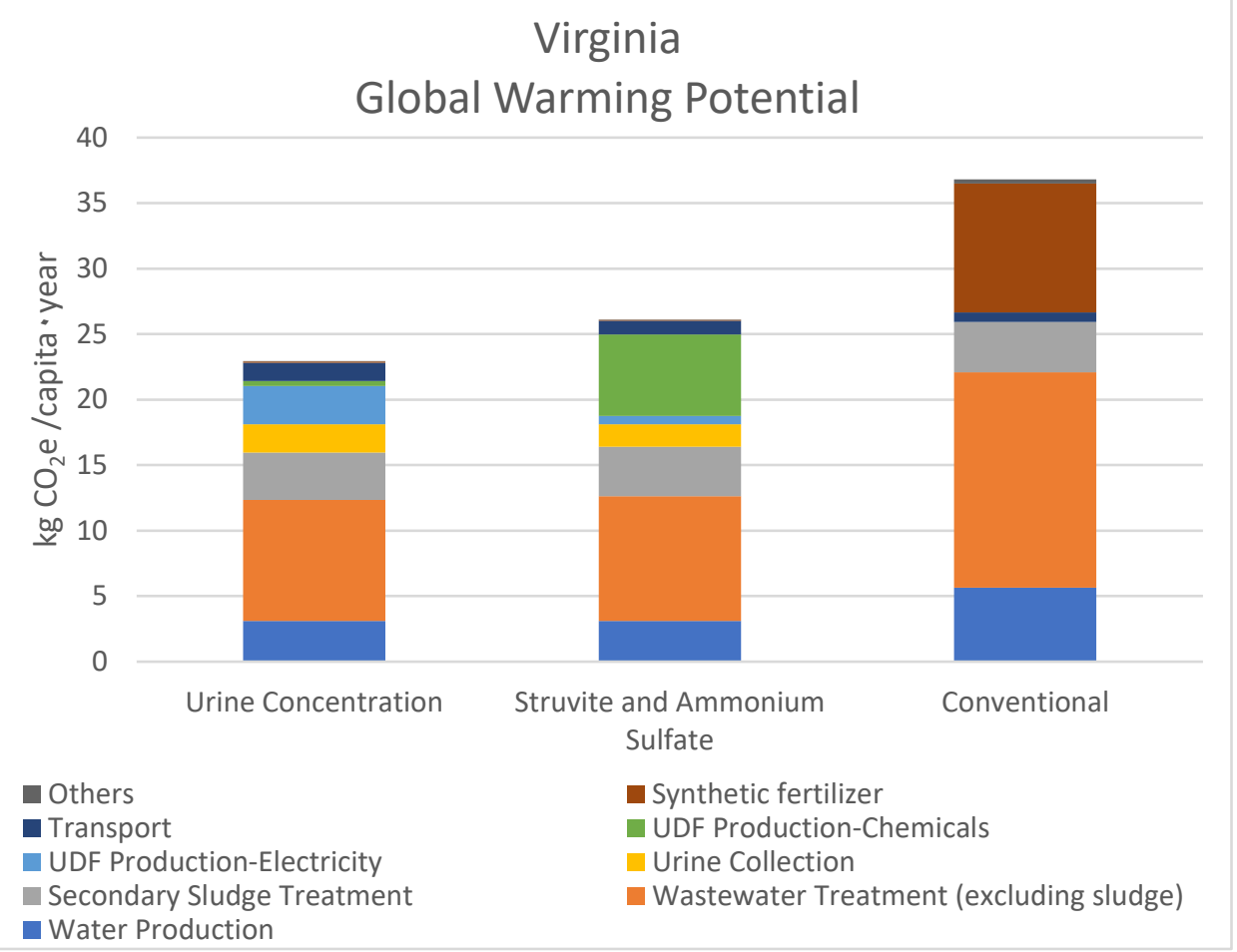

Figure 3. GWP by Process.

Global warming potential of the Virginia alternatives broken down by process.

In the conventional alternative, 10.4 cubic meters of water were needed per person per year for flushing excluding leaks between the drinking water plant and the consumer. This decreases to 5.3 and 3.1 cubic meters for $70 \%$ and $100 \%$ urine diversion, respectively. Reduced flush volumes from urine-diverting toilets were responsible for the majority of decreased freshwater used although 9 to $11 \%$ came from upstream sources such as production of synthetic fertilizer, ferric chloride, and other chemicals.

For urine collection, producing acetic acid led to higher environmental impacts than the electricity consumed to collect urine. More acetic acid was used to ensure that urine remained stable in the urine concentration alternative. While urine diversion reduced the volume of wastewater that needed to be collected, the impacts of collecting and stabilizing urine were substantially larger than any benefits of collecting less wastewater in sewers. 
Urine-derived fertilizer production resulted in about $21-75 \%$ as much GWP as synthetic fertilizers and decreased most other environmental impacts. The exception was AP, which ranged anywhere from a $77 \%$ decrease to a $231 \%$ increase from synthetic fertilizers. Offsetting synthetic fertilizers was almost always required to reduce GWP and CED.

The impacts of concentrating urine were dominated by electricity consumed for reverse osmosis. Unless urine diversion led to major reductions in electricity consumed at wastewater treatment plants, such as in Virginia, concentration increased total electricity within a municipality. The environmental impacts of producing concentrated urine were low in Vermont due to the high proportion of renewable energy. The impacts of producing struvite and ammonium sulfate were relatively consistent, with sulfuric acid being responsible for much of the GWP and leading to this alternative always having the largest AP. Processes such as regenerating activated carbon, cleaning $\mathrm{RO}$ membranes, producing magnesium oxide and ion exchange resin, and electricity for pumping in the fertilizer production facility had small overall impacts.

The GWP and CED of shipping urine-derived fertilizers to the fertilizer depot comprised a relatively small portion of the net impact, but were up to 3.5 times higher than shipping synthetic fertilizers. Synthetic fertilizers were shipped much longer distances, but only required about 4-8\% as much mass, and were more likely to use larger and more efficient transports.

Urine diversion significantly decreased the impacts (GWP, CED, AP) of nutrient removal from treatment plants with stringent effluent limits, whereas more lenient plants reduced the EP of releasing effluent to aquatic ecosystems. As shown in Figure 4, all treatment plants benefitted by reducing the amount of ferric chloride required to remove phosphorus. Treatment plants with stricter effluent limits had larger reductions of electricity, methanol, and nitrous oxide emissions 
in biological treatment. These benefits were so large in Virginia that even if no synthetic fertilizer were offset, urine diversion would still reduce net greenhouse gas emissions. In certain cases, urine diversion could eliminate the need for ferric chloride and methanol during average conditions. Reducing total wastewater volume, capturing BOD in concentrated urine, and minor changes to secondary sludge production led to small changes in environmental impacts.

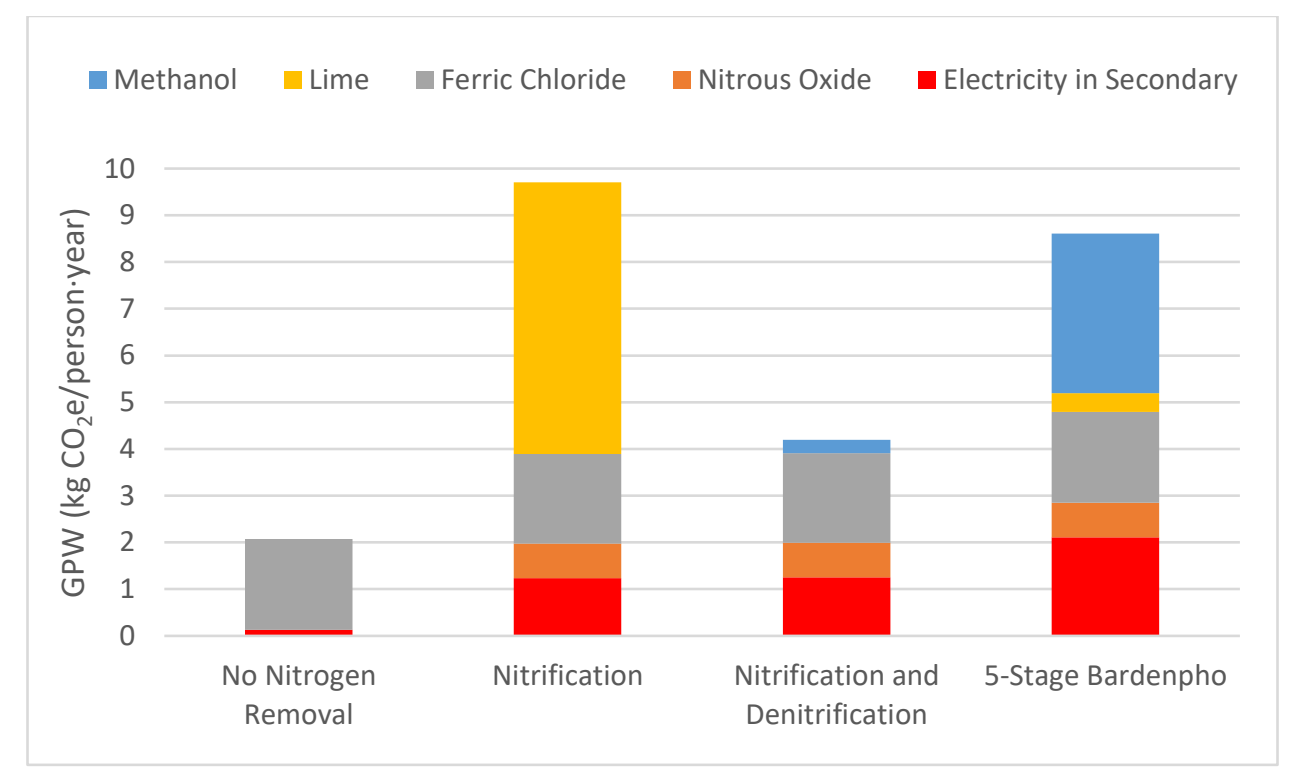

Figure 4. Reductions in GHGs in WWTPs.

Reductions in greenhouse gas emissions from different types of wastewater treatment plants due to $70 \%$ urine diversion. All remove phosphorus and use the Virginia electricity grid to allow comparison. The first type has an aeration basin to remove BOD (Vermont). The second category uses nitrification to oxidize ammonia to nitrate. The third category further treats wastewater with denitrification, which converts some nitrate to nitrogen gas. The final category is the 5-Stage Bardenpho treatment method which removes the most nutrients (Virginia).

Figure 23 shows that the methodology used in this study and the simpler methodologies used in other studies to estimate how much urine diversion reduces greenhouse gas emissions from wastewater treatment are within a reasonable range. ${ }^{48,49}$ However, the benefits from increasing urine are not linear due to elimination of chemical requirements or changes in wastewater treatment plant configuration, so the use of an linear offset results in some level of inaccuracy. 


\subsection{Sensitivity Analysis}

Figures 24-27 demonstrate that the results of this study were largely robust. Urine diversion always decreased freshwater use and EP. The number of repetitions where urine concentration increased GWP and CED were negligible, but occurred occasionally for struvite and ammonium sulfate when renewable electricity was used. Urine concentration alternatives did increase AP in a few repetitions with the Five-Stage Bardenpho when renewable electricity was used, and approximately $30 \%$ of repetitions in the single aeration basin. The AP for struvite and ammonium sulfate was always higher than the conventional alternative even as the efficiency of ammonium sulfate use approached 100\%. Figures 28 and 29 show that urine concentration typically had a better environmental performance than struvite and ammonium sulfate. These differences were more pronounced when producing electricity had lower environmental impacts because the added burden of electricity consumption to concentrate urine was lessened. Environmental improvements in GWP, CED, and AP categories are highest in locations with electricity produced from fossil fuels and large levels of nutrient removal, as shown in Figures 24-27. Environmental improvements are also greater in locations with less wastewater volume per person and lower performing aeration systems.

Tables 22 and 23 show that excluding fertilizer offsets and nitrous oxide emissions from effluents from the scope can change the conclusion of the analysis. As the environmental impact of producing electricity decreased, reducing greenhouse gases without considering fertilizer is less likely. The exception is for urine concentration alternatives with limited nutrient removal because net electricity consumption in a municipality increases. When nitrous oxide emissions from effluent were not considered, urine diversion almost never decreased greenhouse gas emissions from single aeration basin systems that use renewable electricity. 


\section{DISCUSSION}

Similar to other life cycle assessments, ${ }^{48,49,51}$ this study found urine diversion reduced most environmental impacts. It expanded upon previous research by conducting a more comprehensive characterization of wastewater treatment and by evaluating a range of large-scale systems. Simpler methods to estimate the changes in environmental impacts of treating wastewater are valid as an approximation, but the more complete methods used in this study may be more appropriate when increased accuracy is needed or when different extents of urine diversion are being evaluated. Scenario and sensitivity analyses showed that freshwater use and EP impacts were always reduced, GWP and CED were consistently reduced, and urine concentration usually reduced the AP.

Urine collection is the uncertain aspect of this analysis due to a lack of large-scale examples. This study modeled a centralized system conveying urine from an urban area to a central processing facility in order to create a reasonable estimate of the environmental burdens from urine collection. It suggested the importance of the acetic acid dosage used for stabilization. Other options include a more distributed system consisting of multiple processing facilities strategically located throughout an urban area to reduce both the distance collected urine would need to be transported, as well as the transport time which could reduce urine stabilization requirements. The optimal scale of decentralization of urine collection still needs to be assessed. Significant further development of urine collection is certainly possible which could reduce not only cost but environmental impacts.

The advantages urine diversion provides wastewater treatment are clearly demonstrated in this study and corroborated by previous research. ${ }^{18,52}$ Where nutrient removal is practiced, 
these primarily include elimination of chemical inputs (metal salts for phosphorus removal, supplemental carbon such as methanol for nitrogen removal) and reduced energy use. In many cases urine diversion can eliminate the need to expand existing wastewater treatment plants for nutrient removal capabilities. While not considered in this study, eliminating the need for nutrient removal could allow further changes to treatment process such as increased capture and utilization of organic matter contained in the influent wastewater. In locations where nutrient removal is not a goal for wastewater treatment, eutrophication can be reduced as less nutrients are discharged to local waterways. Urine diversion leads to decreases in environmental impacts through a wide range of conditions, but can be a particularly effective decarbonization strategy in areas with high levels of nutrient removal, electricity produced primarily from fossil fuels, and relatively little wastewater per capita.

Producing fertilizer from urine instead of mineral sources leads to significant environmental benefits. These urine-derived fertilizer production methods were characterized using laboratory and demonstration scale-studies, ${ }^{25,26,37-39,54,98}$ but demonstration of other available approaches ${ }^{15,33,40,41,92}$ and larger scale systems will provide an improved basis for assessing environmental impacts. ${ }^{15,33,40,41,92}$ They were selected to represent a range of fertilizer products and production methods. Urine concentration is more heavily dependent on energy, produces a fertilizer with nitrogen in the form of urea, retains much of the potassium in urine, and has a relatively consistent nitrogen-to-phosphorus ratio (depending on the composition of urine and whether additional nutrients are added). Struvite precipitation and ammonium sulfate largely use chemical inputs and could easily be applied with different nitrogen-to-phosphorus ratios. Throughout all electricity grids, the environmental burdens of producing concentrated urine were usually lower even as the efficiency of sulfuric acid use approached $100 \%$. A 
comprehensive environmental evaluation of all the different forms of urine derived fertilizers is needed for a complete life-cycle perspective. The environmental burdens of producing them were lower than synthetic fertilizers, and will be significantly improved as use of sulfuric acid for ion exchange and energy for reverse osmosis are optimized, or renewable energy is used for urine concentration.

The urine-derived fertilizers evaluated could be applied similarly to fertilizers commonly used in the US. ${ }^{99}$ Beyond the impacts of fertilizer production, other important factors such as the higher popularity of single-nutrient fertilizers will affect which fertilizers are produced. ${ }^{99}$ Implementation efforts need to consider the fertilizer demands of adjacent communities and the transportation costs and environmental impacts associated with shipping urine-derived fertilizers from population centers. ${ }^{12,100}$

Urine can replace a significant fraction of synthetic fertilizers. Researchers estimate 1630 kilograms of nitrogen and $4 \mathrm{~kg}$ of phosphorus in fertilizer are currently used per person per year in affluent countries. ${ }^{101-104}$ If all nutrients were recovered from domestic wastewater it would likely produce less than $5 \mathrm{~kg}$ of nitrogen and $1 \mathrm{~kg}$ of phosphorus per person. Regardless, urine diversion can provide significant environmental benefits and can be used with other strategies such as dietary changes, manure application, and reduction of nutrient runoff during mineral extraction and fertilizer application to significantly improve nutrient use efficiency. ${ }^{101,102}$

The development of large-scale urine collection and processing systems is still at a conceptual stage. Research is ongoing to understand and address the many challenges of urine diversion, including economic, market and regulatory acceptance, ${ }^{12,26,105-108}$ potential user error, ${ }^{26,109}$ risk aversion and lack of confidence in performance, ${ }^{8,106,107}$ and lock-in to conventional systems. ${ }^{107,110}$ Irrespective of the urine processing method considered, net benefits 
were observed for each scenario evaluated. In some cases the environmental benefits associated with water and wastewater management alone were sufficient to offset the environmental burden associated with urine collection, processing, and transport. The analyses presented here clearly indicate that the more well-defined benefits (reduced wastewater management requirements and avoided synthetic fertilizer production) exceed the environmental impacts of urine collection, processing, and transport, suggesting that further efforts to develop such systems are warranted. 


\section{APPENDIX A: SYSTEM SCOPE AND BOUNDARY}

This section will provide a more in-depth description of what is and is not included in the scope of this study. This study only considers the use phase, so burdens from infrastructure and decommissioning are excluded. There are important exclusions from the use phase, so the impacts should not be interpreted as the total impact of the urban water system.

In order to conduct this Life Cycle Assessment (LCA), mass balances were tracked through much of the urban water cycle. The environmental impacts of managing some of these flows were quantified. While this study evaluates certain environmental burdens of processes that remove pharmaceuticals from urine, a mass balance on pharmaceuticals was not conducted. The impacts from releasing pharmaceuticals into aquatic or terrestrial ecosystems were not considered.

Relevant material flows fall into four general categories:

1. Mass, volume, and environmental impacts are considered.

2. Only the mass and volume are considered.

a. For example, considering other wastewater flows (e.g. stormwater) to estimate wastewater dilution.

3. Mass, volume, and environmental impacts are excluded from consideration due to similarity between alternatives.

a. For example, primary sludge was not tracked because it is assumed that it will be unaffected by urine diversion.

4. The mass, volume, and environmental impacts were excluded due to a lack of data. These flows are displayed in Figure 5 and explained below. 


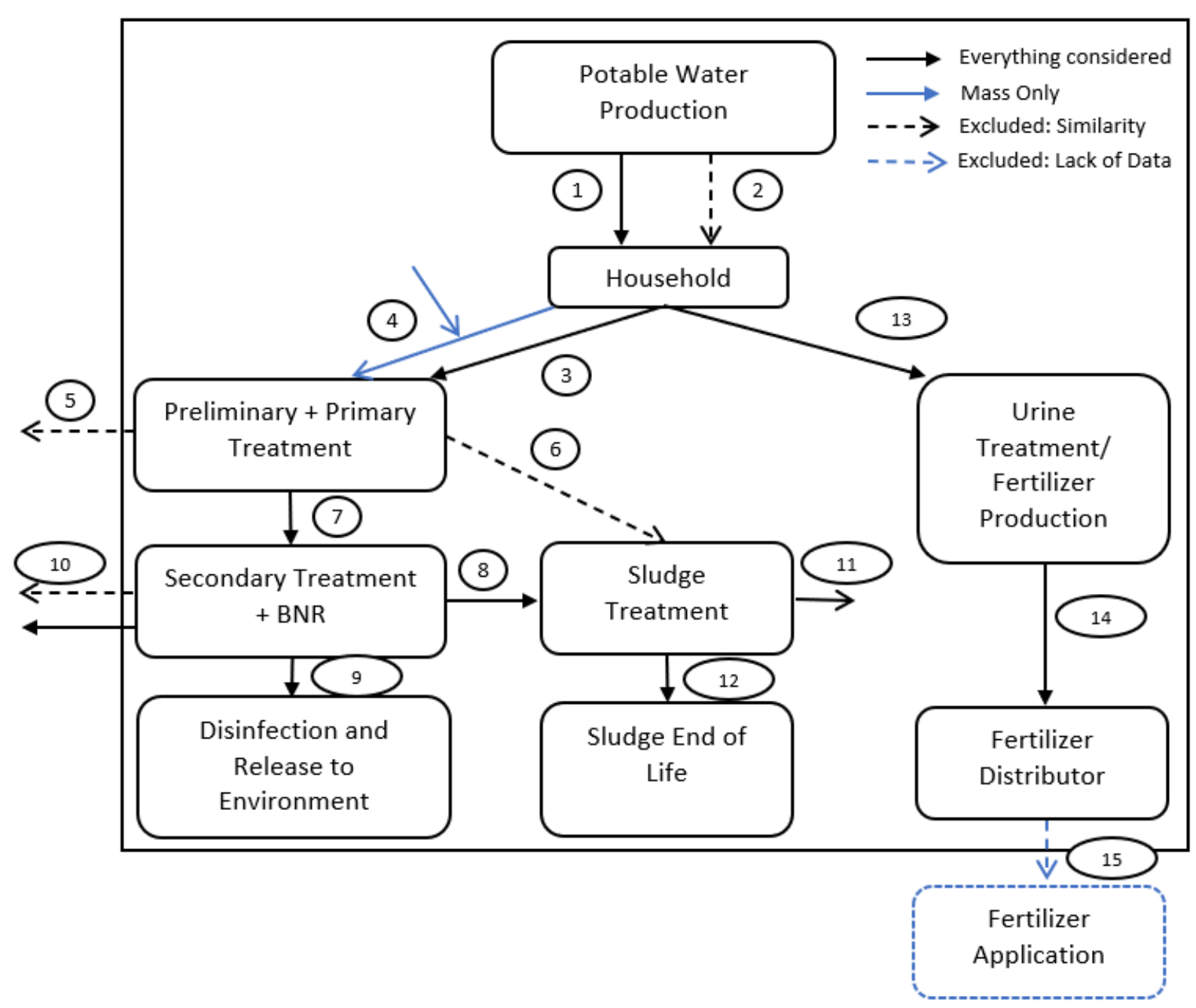

Figure 5. Detailed description of Study Scope.

Depiction of all flows and the extent to which they were accounted for in this study.

1. Potable water produced for flushing. The mass, impact of treatment, and impact of delivery to the household were considered.

a. Impacts of delivering chemicals to the water treatment plant are included. This is also the case for the wastewater treatment plant, the urine-derived fertilizer plant, and the acetic acid used for urine collection. 
2. Potable water produced for other purposes. This was excluded under the assumption that urine diversion will not affect other uses of water. Activities unrelated to urine diversion such as heating water were also excluded.

3. Flush water and excrement that are not diverted. The mass, nutrient composition, and environmental impact of transporting this sewage from households to the sewer were accounted for.

a. The impact of conveyance only included the energy consumption for sewage lifts. Direct emissions from sewers were not accounted for.

4. Greywater and rainwater collection: The impact of collecting this water is not considered in the final analysis. This is because it is assumed that urine diversion will not change the volume of greywater and rainwater collected. However, the masses of pollutants and total volume was considered in order to later determine the wastewater strength.

a. Flows 3, 4, and reject water from urine derived fertilizer production are treated as if they mix at the wastewater treatment plant. Because these sources of water contribute some pollutants and much of the volume, tracking these flows are essential for accurate wastewater treatment modeling.

5. Solids from preliminary treatment hauled to a landfill: The mass and environmental impacts were excluded because it was assumed that urine diversion would not affect the solids removed from grit screens, grit chambers, or other forms of preliminary treatment.

6. Treatment of sludge produced in primary treatment: The mass, volume, and environmental impacts were excluded because it was assumed that urine diversion would not affect the mass of primary sludge produced or its composition. 
7. Secondary treatment and nutrient removal: The total wastewater volume, mass of all major pollutants, and inputs necessary for secondary treatment were included.

8. Treatment of sludge produced in biological wastewater treatment: The dry mass of sludge produced, the volume of sludge, and all necessary treatment were included. This was done in order to capture changes in sludge production due to urine diversion.

9. Disinfection and release of wastewater to the environment: The amount of water released, the disinfection chemicals and energy, and the eutrophication impact for nutrients were accounted for.

10. Direct emissions of greenhouse gases during biological treatment: As wastewater undergoes biological treatment, much of the carbon in wastewater is released as carbon dioxide. Similar to other LCAs, these emissions were excluded under the assumption that they had biogenic origins. ${ }^{111,112}$ While some argue that a considerable portion of direct carbon dioxide emissions are not biogenic (e.g. detergents with fossil inputs), ${ }^{113}$ urine diversion was assumed to not affect the amount non-biogenic carbon in influent wastewater.

a. Other gases, notably nitrous oxide, were accounted for.

b. Urine diversion could affect the amount of non-biogenic carbon if it reduces the carbon inputs added during wastewater treatment for denitrification (e.g. methanol). The production of any carbon added is considered, but not the amount converted to carbon dioxide during wastewater treatment.

11. Production of biogas from anaerobic digestion: Electricity from biogas production was estimated and subtracted from electricity used in wastewater treatment. 
12. Sludge end of life: The impacts of transporting sludge to its end of life and environmental burdens thereafter were considered. It was assumed that the end of life for sludge was either land application or disposal in a landfill.

a. For sludge transportation, the mass depended on whether it was anaerobically digested, composted, lime stabilized, thermally dried, or incinerated.

b. Included impacts for land application included direct emissions of gases and pollutants to water that can lead to the greenhouse effect, eutrophication, or acidification. Estimates for offset nitrogen and phosphorus fertilizer are also included.

c. Considered impacts for landfills were fugitive greenhouse gas emissions from uncaptured Landfill Gas.

13. Collection and treatment of separated urine, flushwater, and acetic acid: The total mass of nutrients, volume, and impacts from collecting urine and converting it to fertilizer are included.

a. Infrastructure is excluded, but some equipment is included. This includes the reverse osmosis membranes and the activated carbon columns, including the fiberglass casing.

b. The impact of packaging urine derived fertilizer was not quantified. This is consistent with the data used for synthetic fertilizers, which also do not include the impact of packaging.

c. The volume of reject water sent to the wastewater treatment plant, as well as treatment burdens, are considered. 
14. Transportation of fertilizers to a fertilizer distributor: The mass of fertilizer delivered and the impact of transportation to a fertilizer distributor are accounted for.

15. Transportation of fertilizers to the farm and application: The transportation of fertilizer from the distributor to the farm, the energy needed for application, and emissions of the fertilizer after application are not considered.

a. It is worth noting that the vehicles that are transporting fertilizer are likely less efficient than the vehicles that bring fertilizer to the fertilizer distributor. This could be important as liquid urine-derived fertilizers require more mass and volume than synthetic fertilizers to deliver the same quantity of nutrients.

b. It is not entirely clear how, if at all, emissions from applying urine-derived fertilizers would differ from applying urine-derived fertilizers. Due to some research on the topic it was assumed they do not differ significantly. ${ }^{25}$

i. Some researchers suggest that due to the slow releasing nature of fertilizers such as struvite that runoff emissions may be lower. ${ }^{35,38}$ This has not yet been quantified well enough to include in this study.

ii. The extent of nutrient runoff and nitrous oxide emissions likely differ depending on many soil and climate factors, so if these impacts had been quantified the data quality of these emissions would be low at best. 


\section{APPENDIX B: WASTEWATER TREATMENT MODELING B1 Influent, Preliminary and Primary Treatment}

The water and excrement from non-diverted flushes, effluent from urine derived fertilizer production, grey water, and rain water were assumed to be mixed before wastewater treatment began. The volume and major constituents of wastewater per capita for the conventional and urine diversion alternatives are shown in Table 4. All scenarios assumed 256 liters of grey and rainwater per person per day based off of current estimates for total wastewater volume ${ }^{114}$ and the current average volume of water for flushing ${ }^{85}$ The nutrient content of greywater, urine, and feces per capita were obtained from the literature. ${ }^{13,114-118}$ Wastewater per capita was not varied between scenarios because of a lack of data on indoor water use and sewer leaking and infiltration by state.

Table 4. Primary Influent per Capita.

\begin{tabular}{|l|l|l|l|}
\hline & $\begin{array}{l}\text { Struvite and } \\
\text { Ammonium } \\
\text { Sulfate }\end{array}$ & $\begin{array}{l}\text { Urine } \\
\text { Concentration }\end{array}$ & Conventional \\
\hline Volume (L/day) & 266 & 266 & 283 \\
\hline Total Nitrogen (g/day) & 5.60 & 5.72 & 13 \\
\hline $\begin{array}{l}\text { Total Phosphorus } \\
\text { (g/day) }\end{array}$ & 1.51 & 1.46 & 2.10 \\
\hline COD (g/day) & 180 & 171 & 180 \\
\hline
\end{tabular}

Electricity consumption for primary and preliminary treatment is listed in Table 9. Table 5 lists the percent of each contaminant removed during primary clarification. The impacts of sending screenings to a landfill, any direct emissions, and primary sludge pumping and production are excluded. 
Table 5. Primary Removal Efficiencies.

The following percent of each constituent is assumed to be removed at the primary clarifier. TSS is short for Total Suspended Solids. VSS is short for Volatile Suspended Solids. TKN is short for Total Kjeldahl Nitrogen.

\begin{tabular}{|l|l|}
\hline Constituent & $\begin{array}{l}\text { Percent } \\
\text { Removal }\end{array}$ \\
\hline Ammonia & 0 \\
\hline $\begin{array}{l}\text { Total } \\
\text { Phosphorus }\end{array}$ & $15 \%$ \\
\hline $\begin{array}{l}\text { Organic } \\
\text { Phosphate }\end{array}$ & $15 \%$ \\
\hline COD & $35 \%$ \\
\hline BOD5 & $45 \%$ \\
\hline TSS & $60 \%$ \\
\hline VSS & $60 \%$ \\
\hline
\end{tabular}

\section{B2 Secondary Treatment and Nutrient Removal}

Secondary treatment and nutrient removal were modeled to elucidate the environmental ramifications of urine diversion on wastewater treatment. This facilitates determination of whether or not urine diversion can change important operating conditions, such as the solids retention time (SRT), treatment plant configuration, and oxygen demand. ${ }^{52,119,120}$ The environmental impacts quantified for this stage of treatment include the eutrophication potential of the effluent, direct emissions of greenhouse gases, electricity consumption, sludge production, and chemical consumption.

\section{B2.1 Conversion Factors Used in Biological Wastewater Treatment Modeling}


The constituents tracked in the mass balance needed to be converted using the characterization factors in Table 6 to allow modeling of biological treatment. ${ }^{121,122}$

Table 6. Wastewater Conversion Factors.

\begin{tabular}{|c|c|}
\hline Fraction & Value \\
\hline Readily biodegradable: Total COD & 0.15 \\
\hline Non-colloidal slowly biodegradable: Total COD & 0.85 \\
\hline Soluble Biodegradable Organic Nitrogen: TKN & 0.149 \\
\hline Particulate Biodegradable Organic Nitrogen: Total N & 0.195 \\
\hline Particulate Inert Organic Matter: VSS & 0.56 \\
\hline
\end{tabular}

This study modeled growth, decay, hydrolysis, ammonification and yield for ordinary heterotrophic organisms (OHOs). Decay and yield were modeled for autotrophic organisms. The parameters listed in Table 7 are used to model microbial metabolic activity for these organisms. The Arrhenius rule is used to adjust these parameters for different temperatures.

Table 7. Parameters used to model metabolic activity.

\begin{tabular}{|l|l|l|l|}
\hline Parameters & Description & Unit & $\begin{array}{l}\text { Value under } \\
20^{\circ} \mathrm{C}\end{array}$ \\
\hline IO $/ \mathrm{XB}, \mathrm{T}$ & Conversion factor from TSS unit to COD units & gCOD/gTSS & 1.2 \\
\hline $\mathrm{b}_{\mathrm{H}, \mathrm{AER}}$ & Aerobic Decay of OHOs & $1 / \mathrm{d}$ & 0.62 \\
\hline $\mathrm{b}_{\mathrm{H}, \mathrm{ANX}}$ & $\begin{array}{l}\text { Anoxic/anaerobic Decay } \\
\text { of OHOS }\end{array}$ & $1 / \mathrm{d}$ & 0.3 \\
\hline $\mathrm{k}_{\mathrm{a}}$ & Ammonification Rate of OHOs & L/(mgN d) & 0.04 \\
\hline $\mathrm{f}_{\mathrm{D}}$ & $\begin{array}{l}\text { Fraction of active biomass contributing to } \\
\text { debris for OHOs }\end{array}$ & - & 0.2 \\
\hline $\mathrm{Y}_{\mathrm{H}, \mathrm{T}}$ & Yield of OHOs & $\begin{array}{l}\mathrm{mg} \mathrm{TSS} / \mathrm{mg} \\
\mathrm{COD}\end{array}$ & 0.5 \\
\hline
\end{tabular}




\begin{tabular}{|l|l|l|l|}
\hline$b_{A}$ & Autotrophic decay & $1 / \mathrm{d}$ & 0.17 \\
\hline$Y_{A, T}$ & Yield of autotrophic organisms & $\begin{array}{l}\mathrm{mg} \mathrm{TSS} / \mathrm{mg} \\
\mathrm{COD}\end{array}$ & 0.15 \\
\hline
\end{tabular}

This study modeled growth, decay, hydrolysis, ammonification and yield for ordinary heterotrophic organisms (OHOs). Decay and yield were modeled for autotrophic organisms. The parameters listed in Table 8 are used to model microbial metabolic activity for these organisms. The Arrhenius rule is used to adjust these parameters for different temperatures.

Table 8. Parameters used to model metabolic activity.

\begin{tabular}{|c|c|c|c|}
\hline Parameters & Description & Unit & $\begin{array}{l}\text { Value under } \\
20^{\circ} \mathrm{C}\end{array}$ \\
\hline $\mathrm{i}_{\mathrm{O} / \mathrm{XB}, \mathrm{T}}$ & $\begin{array}{l}\text { Conversion factor from TSS unit to COD } \\
\text { units }\end{array}$ & gCOD/gTSS & 1.2 \\
\hline$b_{H, A E R}$ & Aerobic Decay of OHOs & $1 / \mathrm{d}$ & 0.62 \\
\hline $\mathrm{b}_{\mathrm{H}, \mathrm{ANX}}$ & $\begin{array}{l}\text { Anoxic/anaerobic Decay } \\
\text { of OHOs }\end{array}$ & $1 / \mathrm{d}$ & 0.3 \\
\hline $\mathrm{k}_{\mathrm{a}}$ & Ammonification Rate of OHOs & $\mathrm{L} /(\mathrm{mgN} d)$ & 0.04 \\
\hline$f_{D}$ & $\begin{array}{l}\text { Fraction of active biomass contributing to } \\
\text { debris for OHOs }\end{array}$ & - & 0.2 \\
\hline $\mathrm{Y}_{\mathrm{H}, \mathrm{T}}$ & Yield of OHOs & $\begin{array}{l}\mathrm{mg} \mathrm{TSS} / \mathrm{mg} \\
\mathrm{COD}\end{array}$ & 0.5 \\
\hline$b_{A}$ & Autotrophic decay & $1 / \mathrm{d}$ & 0.17 \\
\hline $\mathrm{Y}_{\mathrm{A}, \mathrm{T}}$ & Yield of autotrophic organisms & $\begin{array}{l}\mathrm{mg} \mathrm{TSS} / \mathrm{mg} \\
\mathrm{COD}\end{array}$ & 0.15 \\
\hline
\end{tabular}

\section{B2.2 Effluent Quality}

\section{B2.2.1 COD, Total Phosphorus, Ammonia-Nitrogen}


The rule-based model used for this study continued treatment until the concentration of all regulated contaminants were at or below regulatory levels. This determined important operating characteristics such as the solids retention time or the treatment plant configuration. The effluent COD concentration is assumed to be equal to the effluent standard.

In cases where the influent concentration of phosphorus is less than the effluent standard, the effluent concentration is determined by the phosphorus in the influent and the phosphorus removed by biomass production. When the secondary influent is in excess of the effluent standard, the effluent concentration is assumed to be equal to the effluent standard. Phosphorus is removed by either biological methods, chemical methods, or both.

Systems with anaerobic zones (e.g. the Five-Stage Bardenpho treatment plant in the Virginia scenario) use Phosphorus-Accumulating Organisms (PAOs) to remove phosphorus. It is assumed that 10.7 grams of Volatile Fatty Acids as COD are required to remove one gram of phosphorus. $^{122}$ If there is not enough volatile fatty acids to remove the required phosphorus biologically or if the treatment plant does not use biological phosphorus removal, the remaining phosphorus requiring removal is precipitated with ferric chloride.

When the concentration of ammonia-nitrogen in the influent is lower than the effluent standard, the effluent concentration is assumed to be equal to the influent concentration. When the concentration of ammonia-nitrogen is higher than the effluent standard, nitrification is induced and the concentration is assumed to be equal to the effluent standard.

\section{B2.2.2 Nitrate and Total Nitrogen}

Nitrate formed during nitrification 
The treatment plant modeled for the Virginia scenario and some of the treatment plants modeled for the Michigan scenario use nitrification and denitrification to reduce the concentration of total nitrogen in the effluent. First, the concentration of nitrate formed during nitrification is calculated using equation $1 .{ }^{122}$

$S_{N O}=0.98\left(S_{N, a}-S_{N H}-S_{N S}\right)$ (equation 1)

Where: $S_{N O}=$ Nitrate Formed by nitrification

$S_{N, a}=$ Nitrogen available to nitrifiers

$S_{N H}=$ Effluent Ammonia Nitrogen concentration, set as the effluent standard $S_{N S}=$ Effluent soluble organic $\mathrm{N}$ concentration

The concentration of nitrogen available to nitrifiers is calculated using equation $2 .^{122}$

$S_{N, a}=S_{N H 0}+S_{N S 0}+X_{N S 0}-N R\left(S_{S 0}+X_{S 0}-S_{S}\right)$

(equation 2)

Where: $S_{N H 0}=$ influent soluble ammonia $\mathrm{N}$ concentration

$S_{N S 0}=$ soluble biodegradable $\mathrm{N}$ concentration

$X_{N S 0}=$ particulate biodegradable organic $\mathrm{N}$ concentration

$N R=$ Nitrogen required for heterotroph growth

$S_{S 0}=$ influent readily biodegradable COD concentration

$X_{S 0}=$ influent slowly biodegradable COD concentration

$S_{S}=$ effluent COD concentration, which is determined by standard

Equation 3 is used to determine the nitrogen required for heterotroph growth. ${ }^{122}$

$N R=0.087 \frac{\left(1+f_{D} b_{H} S R T_{I A Z+P A Z}\right) Y_{H, T} i_{O / X B, T}}{\left(1+b_{H} S R T_{I A Z+P A Z}\right)}$

(equation 3)

Where: $S R T_{I A Z+P A Z}=$ Solids Retention time of the initial anoxic zone and the primary aerobic zone, days 


\section{Denitrification}

The Modified Ludzack-Ettinger (MLE) treatment plants that were a part of the Michigan scenario had denitrification in one zone. The Five-Stage Bardenpho plant modeled for the Virginia scenario had denitrification in two zones. Some of the processes to model the initial anoxic zone for the Five-Stage Bardenpho plant and the only anoxic zone for the MLE are described below. Then, the processes to model the second denitrification zone for the Five-Stage Bardenpho plant will be described.

Denitrification in the Initial Anoxic Zone

Both readily and slowly biodegradable substrate are assumed to be available for denitrification due to a long enough Solids Retention Time ( $>3$ days). External carbon sources such as methanol are added when there is not enough biodegradable substrate for nitrate removal.

Denitrification associated with both slowly biodegradable substrate and denitrification associated with readily biodegradable substrate are included. Equation 4 is used to estimate the mass rate of denitrification associated with utilization of slowly biodegradable substrate. The concentration of the Mixed Liquor Suspended Solids (MLSS) is assumed to be 3,500 grams of TSS per cubic meter.

$\Delta N_{X S}=q_{N O / X S} M L S S_{I A Z}$ (equation 4)

Where: $N X S=$ mass rate of denitrification, grams nitrate-N per day

$q_{N O / X S}=$ Specific Nitrate-N Utilization Rate, grams nitrate-N per gram MLSS per day $M L S S_{I A Z}=$ Concentration of MLSS in the Initial Anoxic Zone 
The specific nitrate-N utilization rate associated with slowly biodegradable COD is calculated using equation 5.

$q_{N O / X S}=0.018 U_{A N X}+0.029$

(equation 5)

Where: $U_{A N X}=$ the loading factor for slowly biodegradable substrate to the anoxic zone

The loading factor for slowly biodegradable substrate to the anoxic zone (UANX) is calculated using Equation 6.

$U_{A N X}=F \cdot S_{S 0} \cdot M L S S_{I A Z}$ (equation 6)

Where: $M L S S_{I A Z}=$ Mixed Liquor Suspended Solids in the initial anoxic zone

The denitrification rate associated with readily biodegradable substrate is calculated using equation 7 . Then, the effluent nitrate concentration from the primary aerobic zone (CN1) is calculated using equation 8 .

$\Delta N_{S S}=F \cdot S_{S 0} \frac{1-Y_{H, T i O} i_{O / X B, T}}{2.86}$ (equation 7)

$C N 1=S_{N 0}-\Delta N_{X S}-\Delta N_{S S}$ (equation 8)

Denitrification in the Secondary Anoxic Zone

For the secondary anoxic zone, the Burdick empirical relationship (eq. 9) is used to estimate the specific denitrification rate.

$q_{N O / X B}=0.12 S R T_{T O T}^{-0.706}$

(equation 9)

This is then used in equation 10 to estimate the denitrification mass rate. 
Where: $M L S S_{S A Z}=$ Concentration of Mixed Liquor Suspended Solids in the secondary anoxic zone

The effluent loads of these species and TRACI impact factors are used to determine the eutrophication potential of wastewater. ${ }^{123}$

\section{B2.3 Direct Greenhouse Gas Emissions}

Wastewater treatment can lead to considerable emissions of carbon dioxide and nitrous oxide. This study did not estimate direct emissions of carbon dioxide under the assumption that they are predominately biogenic, and that urine diversion will not affect the amount of carbon dioxide from fossil origin. In reality, this is a conservative approach because urine diversion may decrease direct carbon dioxide emissions because it can decrease the input of fossil carbon inputs, such as methanol.

Nitrous oxide emissions have been observed in treatment plants that utilize nitrification and denitrification. Nitrous oxide emitted during wastewater treatment and after wastewater is released in the environment can be found in Table 10. It is worth noting that nitrous oxide emissions are very uncertain, and different methodologies have been used in other studes. ${ }^{121,124-}$ 126

\section{B2.4 Electricity Consumption}

\section{B2.4.1 Oxygen Demand}

Aeration is one of the largest environmental impacts of wastewater treatment, and be significantly affected by the concentration of nutrients in wastewater. As shown in equation 11, 
the total oxygen demand depends on the oxygen demand of heterotrophic and autotrophic organisms.

$R O_{\text {tot }}=R O_{H}+R O_{A}$

(equation 11)

Equation 12 is used to calculate the oxygen demand from heterotrophic organisms. This is determined by the amount of COD removed and metabolic characteristics of these organisms.

$R O_{H}=F\left(S_{S 0}+X_{S O}-S_{S}\right)\left[1-\frac{\left(1+f_{D} b_{H} S R T_{T O T}\right) Y_{H, T} i_{O / X B, T}}{1+b_{H} S R T_{T O T}}\right]$

(equation 12)

Where: $F=\mathrm{m}^{3}$ wastewater treated per day

$S_{S 0}=$ Influent readily biodegradable COD

$X_{S 0}=$ Influent slowly biodegradable COD

$S_{S}=$ Effluent COD

Treatment plants with ammonia effluent standards also require considerable quantities of oxygen to support autotrophic organisms. In those instances, equation 13 is used to quantify the oxygen demand of these organisms.

$R O_{A}=F\left(S_{N, a}-S_{N H}\right)\left[4.57-\frac{\left(1+f_{D} b_{A T O T} S R T_{T O T}\right) Y_{A, T} i_{O / X B, T}}{1+b_{A} S R T_{T O T}}\right]$

(equation 13)

\section{B2.4.2 Other Electricity Demand}

Electricity is also consumed for mixing and pumping wastewater. For both anaerobic and anoxic zones, it is assumed that 5 watts per cubic meter of reactor volume is needed. It is assumed that influent wastewater, Return Activated Sludge (RAS), Mixed Liquor Recirculation (MLR), and Waste Activated Sludge (WAS) are pumped at 70\% efficiency with head losses described in Table 9. 
Table 9. Pumping head in secondary treatment.

\begin{tabular}{|l|l|}
\hline Pumping Process & Head (meter) \\
\hline Influent wastewater & 1 \\
\hline RAS & 7 \\
\hline MLR & 1 \\
\hline WAS & 7 \\
\hline
\end{tabular}

\section{B2.5 Sludge Production}

Urine diversion has the potential to prevent the need for more complex wastewater systems, which can change important operating parameters such as the solids retention time. This can ultimately change the total quantity of sludge produced. Equation 14 is used to estimate the dry mass of biosolids produced.

$W A S_{T S S}=\frac{W(1+\alpha)}{(W+\alpha) M L S S}$ (equation 14)

Where: $W A S_{T S S}=$ grams TSS per day of biosolids

$W=$ Wastage Ratio

$\alpha=$ Solids Recycle Ratio, assumed to be 0.5

$M L S S=$ Concentration of Mixed Liquor Suspended Solids, grams TSS per cubic meter

The wastage ratio is calculated using equation 15 .

$W=\frac{\alpha \cdot V}{(1+\alpha) S R T_{T o t} \cdot F-V}$

The processes used to treat sludge can be found in Table 11 and section 3.5.

\section{B2.6 Chemical Consumption}


This study included chemical consumption for phosphorus removal, disinfection, alkalinity adjustment, and external carbon addition. Ferric chloride was used to precipitate phosphorus. The amount of phosphorus requiring chemical precipitation is described in section 2.2.2.1. Sodium hypochlorite was assumed to be the disinfectant used in all wastewater treatment plants. The dosage used for both can be found in Table 10. Lime was used for alkalinity adjustment, and methanol was used as the external source of carbon. The dosage for each chemical depends on the biological processes occurring during treatment and are described below.

\section{B2.6.1 Alkalinity Adjustment with Lime}

The assumed initial alkalinity in all systems was 200 milligrams as calcium carbonate per liter. If enough alkalinity is consumed by biological processes such as nitrification that the alkalinity would drop below 50 milligrams as calcium carbonate per liter, lime is added. Each gram of lime provides 1.35 grams of alkalinity as Calcium Carbonate. ${ }^{127}$

Nitrification of ammonia to nitrate consumes alkalinity. ${ }^{122}$ Equation 16 is used to calculated alkalinity destroyed in treatment plants with nitrification but no denitrification.

$A l k_{d e s}=7.23 \cdot S_{N 0}$

Where: $A l k_{d e s}=$ Alkalinity destroyed, in grams per cubic meter

$S_{N 0}=$ Concentration of Nitrate- $\mathrm{N}$ formed, in grams per cubic meter

Converting nitrate to nitrogen gas through denitrification produces alkalinity. Equation 17 is used for treatment plants with nitrification and denitrification.

$A l k_{d e s}=7.23 \cdot S_{N 0}-3.5 \cdot\left(S_{N 0}-S_{N}\right)$ (equation 17) 
Where: $S_{N}=$ Concentration of effluent Nitrate-N in grams per cubic meter, set by effluent standard

\section{B2.6.2 External Carbon Provided from Methanol}

Many treatment plants add an external carbon source to ensure a high enough carbon to nitrogen ratio during denitrification. As shown in equation 18 , this is done by finding the difference between the ideal readily biodegradable substrate and the actual readily biodegradable substrate. Additional substrate is provided in the form of methanol. The assumed COD of methanol is assumed to be $1.2 \mathrm{~kg} / \mathrm{L}$.

Required Additional Substrate $(m g / L)=\Delta S_{T i}-F \cdot S_{S 0}$

Where: $\Delta S_{T i}=$ Ideal mass rate of readily biodegradable substrate for denitrification, grams per day

The ideal concentration of readily biodegradable substrate is found using the required denitrification mass rate and yield, as shown in equation 19.

$\Delta S_{T i}=\frac{\left(\Delta N_{S T}+\Delta N_{X B}\right)}{\left(1-Y_{H, T} i_{O / X B, T}\right) / 2.86}$

Where: $\Delta N_{S T}=$ Required Mass Denitrification Rate from readily biodegradable COD in initial anoxic zone

$\Delta N_{X B}=$ Denitrification mass rate in the secondary anoxic zone

The required mass rate of denitrification associated with utilization of readily biodegradable COD in the initial anoxic zone is determined using equation 20.

$\Delta N_{S T}=F \cdot S_{N O}-\Delta N_{X S}-\Delta N_{X B}-W A S_{T N}-\left(F-F_{W}\right) S_{T N, e f f}$

(equation 20) 
Where: $N X S=$ Denitrification mass rate from slowly biodegradable substrate in the initial anoxic zone

$W A S_{T N}=$ Wastage nitrogen mass rate, grams of nitrogen per day

$F_{W}=$ Flow rate of waste sludge, cubic meters per day

$S_{T N, e f f}=$ Concentration of nitrogen in effluent, grams of nitrogen per day 


\section{APPENDIX C: LIFE CYCLE ASSESSMENT DATA}

A more complete list of parameters used for the Life Cycle Assessment are provided in Table 10, followed by discussion on certain calculations.

Table 10. List of inputs used to model the life cycle assessment.

\begin{tabular}{|c|c|c|c|c|c|}
\hline Used For & Parameter & Value & Unit & Source & Notes \\
\hline \multirow[t]{5}{*}{ Household Use } & Flushes per person per day & 5.14 & /pe-day & $85-88$ & \\
\hline & $\begin{array}{l}\text { Percent flushes only } \\
\text { urination }\end{array}$ & 74.1 & $\%$ & $87,89,90$ & \\
\hline & $\begin{array}{l}\text { Conventional Low flow } \\
\text { Toilet Water per Flush }\end{array}$ & 4.84 & L/flush & Kohler & \\
\hline & $\begin{array}{l}\text { Urine Diversion Toilet } \\
\text { Water per flush }\end{array}$ & 0.165 & L/flush & $\begin{array}{l}\text {;8, Raye-Leonard, } \\
\text { personal } \\
\text { conversation. }\end{array}$ & \\
\hline & $\begin{array}{l}\text { Mean Volume of Urine per } \\
\text { day }\end{array}$ & 1.62 & L/pe-day & $86,89,128$ & \\
\hline
\end{tabular}




\begin{tabular}{|c|c|c|c|c|c|}
\hline & $\begin{array}{l}\text { Mean defecation volume } \\
\text { per day }\end{array}$ & 0.233 & L/pe-day & 13,129 & \\
\hline & $\begin{array}{l}\text { 5\% Acetic Acid added } \\
\text { (Urine Concentration) }\end{array}$ & 0.0417 & $\begin{array}{l}\text { L/L urine and } \\
\text { flushwater }\end{array}$ & 25 & $\begin{array}{l}\text { Likely more than } \\
\text { needed, from water with } \\
\text { a high } \mathrm{pH} .{ }^{130}\end{array}$ \\
\hline & $\begin{array}{l}\text { 5\% acetic acid added } \\
\text { (Struvite and Ammonium } \\
\text { Sulfate) }\end{array}$ & 0.0330 & $\begin{array}{l}\mathrm{L} / \mathrm{L} \text { urine and } \\
\text { flushwater }\end{array}$ & Calculated & \\
\hline & Water conveyance losses & 13 & $\%$ & $9,66,131$ & \\
\hline & Electricity to convey water & 0.202 & $\mathrm{kWh} / \mathrm{m}^{3}$ & $16,44,137,64,66,80,132-136$ & \\
\hline Surface Water & Electricity & 0.443 & $\mathrm{kWh} / \mathrm{m}^{3}$ & $9,57,59-62,65,66,132,138$ & \\
\hline Treatment & Alum & 0.0491 & $\mathrm{~kg} / \mathrm{m}^{3}$ & & \\
\hline & Ferric Chloride & 0.00425 & $\mathrm{~kg} / \mathrm{m}^{3}$ & & \\
\hline & Polymer & $\begin{array}{l}1.19 \cdot 10^{-} \\
4\end{array}$ & $\mathrm{~kg} / \mathrm{m}^{3}$ & & \\
\hline & Lime & 0.00493 & $\mathrm{~kg} / \mathrm{m}^{3}$ & & \\
\hline
\end{tabular}




\begin{tabular}{|c|c|c|c|c|}
\hline & Limestone & 0.0203 & $\mathrm{~kg} / \mathrm{m}^{3}$ & \\
\hline & $\mathrm{NaOH}$ & 0.0166 & $\mathrm{~kg} / \mathrm{m}^{3}$ & \\
\hline & HSF & 0.0011 & $\mathrm{~kg} / \mathrm{m}^{3}$ & \\
\hline & Ammonia & $2.10 \cdot 10^{-}$ & $\mathrm{kg} / \mathrm{m}^{3}$ & \\
\hline & Phosphoric acid & 0.028 & $\mathrm{~kg} / \mathrm{m}^{3}$ & \\
\hline & $\mathrm{CO}_{2}$ & 0.0182 & $\mathrm{~kg} / \mathrm{m}^{3}$ & \\
\hline & Chlorine gas & 0.00148 & $\mathrm{~kg} / \mathrm{m}^{3}$ & \\
\hline & Sodium hypochlorite & 0.0129 & $\mathrm{~kg} / \mathrm{m}^{3}$ & \\
\hline & Calcium hydroxide & 0.0138 & $\mathrm{~kg} / \mathrm{m}^{3}$ & \\
\hline & $\mathrm{KMnO}_{4}$ & $\begin{array}{l}1.96 \cdot 10^{-} \\
4\end{array}$ & $\mathrm{~kg} / \mathrm{m}^{3}$ & \\
\hline Groundwater & Electricity & 0.786 & $\mathrm{kWh} / \mathrm{m}^{3}$ & $48,58-60,63-65$ \\
\hline Treatment & Alum & $\begin{array}{l}1.15 \cdot 10^{-} \\
5\end{array}$ & $\mathrm{~kg} / \mathrm{m}^{3}$ & \\
\hline & Lime & 0.0484 & $\mathrm{~kg} / \mathrm{m}^{3}$ & \\
\hline
\end{tabular}




\begin{tabular}{|c|c|c|c|}
\hline Limestone & $\begin{array}{l}2.87 \cdot 10^{-} \\
6\end{array}$ & $\mathrm{~kg} / \mathrm{m}^{3}$ & \\
\hline $\mathrm{NaOH}$ & 0.00997 & $\mathrm{~kg} / \mathrm{m}^{3}$ & \\
\hline HSF & $\begin{array}{l}7.00 \cdot 10^{-} \\
4\end{array}$ & $\mathrm{~kg} / \mathrm{m}^{3}$ & \\
\hline $\mathrm{CO}_{2}$ & 0.0067 & $\mathrm{~kg} / \mathrm{m}^{3}$ & \\
\hline Chlorine gas & 0.0063 & $\mathrm{~kg} / \mathrm{m}^{3}$ & \\
\hline Sodium hypochlorite & $\begin{array}{l}9.72 \cdot 10^{-} \\
4\end{array}$ & $\mathrm{~kg} / \mathrm{m}^{3}$ & \\
\hline $\mathrm{Na}_{2} \mathrm{CO}_{3}$ & $\begin{array}{l}1.44 \cdot 10 \\
5\end{array}$ & $\mathrm{~kg} / \mathrm{m}^{3}$ & \\
\hline Polyphosphates & $\begin{array}{l}1.40 \cdot 10 \\
4\end{array}$ & $\mathrm{~kg} / \mathrm{m}^{3}$ & \\
\hline $\begin{array}{l}\text { Electricity to collect } \\
\text { sewage }\end{array}$ & 0.0941 & $\mathrm{kWh} / \mathrm{m}^{3}$ & $47,134,139-142$ \\
\hline
\end{tabular}




\begin{tabular}{|c|c|c|c|c|c|}
\hline $\begin{array}{l}\text { Wastewater } \\
\text { Collection } \\
\text { energy }\end{array}$ & Urine Collection Electricity & 0.202 & $\mathrm{kWh} / \mathrm{m}^{3}$ & & $\begin{array}{l}\text { Assumed to be same as } \\
\text { pressurized water system }\end{array}$ \\
\hline \multirow{7}{*}{$\begin{array}{l}\text { Struvite and } \\
\text { Ammonium } \\
\text { Sulfate } \\
\text { Production }\end{array}$} & Mg:P ratio & $1.5: 1$ & & $48,54,91,92$ & \\
\hline & Head loss & 4.6 & meters & Assumed & \\
\hline & $\begin{array}{l}\text { Electricity, Struvite } \\
\text { dewatering }\end{array}$ & 0.783 & $\mathrm{kWh} / \mathrm{kg}$ struvite & $\begin{array}{l}\text { Bott, personal } \\
\text { conversation }\end{array}$ & \\
\hline & $\begin{array}{l}\text { Dowex Mac adsorption } \\
\text { density }\end{array}$ & 4.9 & mole/kg resin & 39,49 & \\
\hline & $\begin{array}{l}\text { Sulfuric Acid (18\%) per kg } \\
\mathrm{N}\end{array}$ & 16.7 & $\mathrm{~L} / \mathrm{kg} \mathrm{N}$ & $\begin{array}{l}\text { Tarpeh, personal } \\
\text { conversation }\end{array}$ & \\
\hline & $\begin{array}{l}\text { Nitrogen concentration in } \\
\text { liquid Ammonium Sulfate }\end{array}$ & 59 & $g / L$ & 49 & \\
\hline & $\begin{array}{l}\text { Resin replacement } \\
\text { frequency }\end{array}$ & 5 & years & 49 & \\
\hline
\end{tabular}




\begin{tabular}{|c|c|c|c|c|c|}
\hline & $\begin{array}{l}\mathrm{N} \text { recovered from } \\
\text { ammonium sulfate }\end{array}$ & 96 & $\%$ & $\begin{array}{l}\text { Tarpeh, personal } \\
\text { conversation }\end{array}$ & \\
\hline & $\mathrm{P}$ recovered in struvite & 96 & $\%$ & $48,54,93,94$ & \\
\hline \multirow[t]{6}{*}{$\begin{array}{l}\text { Urine } \\
\text { Concentration }\end{array}$} & $\begin{array}{l}\text { Activated Carbon, } \\
\text { pharmaceutical removed }\end{array}$ & 11 & $\begin{array}{l}\text { g pharmaceuticals } / 100 \\
\text { g resin }\end{array}$ & Norit & $\begin{array}{l}\text { Based off of methylene } \\
\text { blue adsorption }\end{array}$ \\
\hline & $\begin{array}{l}\text { Pharmaceuticals removed } \\
\text { from urine }\end{array}$ & 10 & $\begin{array}{l}\text { mg pharmaceuticals/L } \\
\text { urine }\end{array}$ & & $\begin{array}{l}\text { Very uncertain. Most } \\
\text { (but not all }{ }^{143} \text { ) studies } \\
\text { only focus on a subset of } \\
\text { pharmaceuticals. }\end{array}$ \\
\hline & $\begin{array}{l}\text { Urine concentration } \\
\text { electricity consumption }\end{array}$ & 0.009 & $\begin{array}{l}\mathrm{kWh} / \mathrm{L} \text { permeate } \\
\text { removed }\end{array}$ & $\begin{array}{l}\text { Noe-Hays, personal } \\
\text { conversation }\end{array}$ & \\
\hline & Uconc $\mathrm{N}$ retention & 95 & $\%$ & 95,96 & \\
\hline & Uconc P Retention & 99 & $\%$ & 95,96 & \\
\hline & Uconc COD Retetention & 99 & $\%$ & 95,96 & \\
\hline $\begin{array}{l}\text { Wastewater } \\
\text { Treatment }\end{array}$ & $\begin{array}{l}\text { Primary + Preliminary } \\
\text { Treatment Electricity }\end{array}$ & 0.0301 & $\mathrm{kWh} / \mathrm{m}^{3}$ & $140,141,144,145$ & \\
\hline
\end{tabular}




\begin{tabular}{|c|c|c|c|c|}
\hline Aeration Electricity & 5 & kg air/kWh & & Diffused air systems \\
\hline Ferric Chloride dosage & 10.5 & $\mathrm{~g} \mathrm{FeCl}_{3} / \mathrm{g} \mathrm{P}$ removed & & $\begin{array}{l}\text { Applied when needed to } \\
\text { achieve effluent } \\
\text { standards }\end{array}$ \\
\hline $\begin{array}{l}\mathrm{N}_{2} \mathrm{O} \text { emissions during } \\
\text { treatment }\end{array}$ & 0.10 & $\%$ of influent TN & 146 & $\begin{array}{l}\text { Applied when treatment } \\
\text { plants have intentional } \\
\text { nitrification or } \\
\text { denitrification. Fraction } \\
\text { estimated using values } \\
\text { from this study and total } \\
\text { nitrogen per person. }\end{array}$ \\
\hline $\begin{array}{l}\text { Secondary Clarifier } \\
\text { Electricity }\end{array}$ & 0.0035 & $\mathrm{kWh} / \mathrm{m}^{3}$ & \multirow{2}{*}{114} & \\
\hline $\begin{array}{l}\text { Electricity used for } \\
\text { disinfection }\end{array}$ & $\begin{array}{l}5.50 \cdot 10^{-} \\
4\end{array}$ & $\mathrm{kWh} / \mathrm{m}^{3}$ & & \\
\hline
\end{tabular}




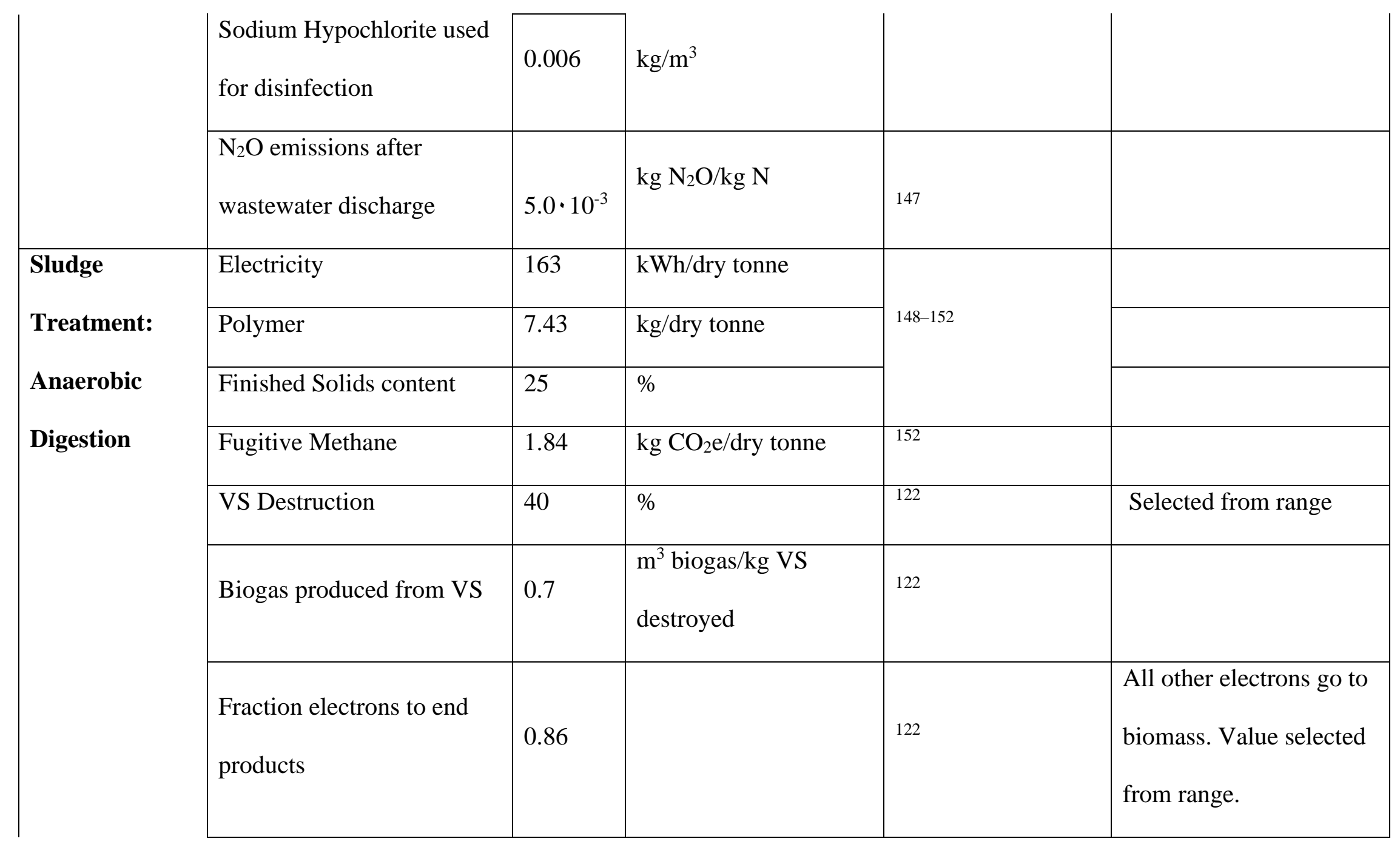




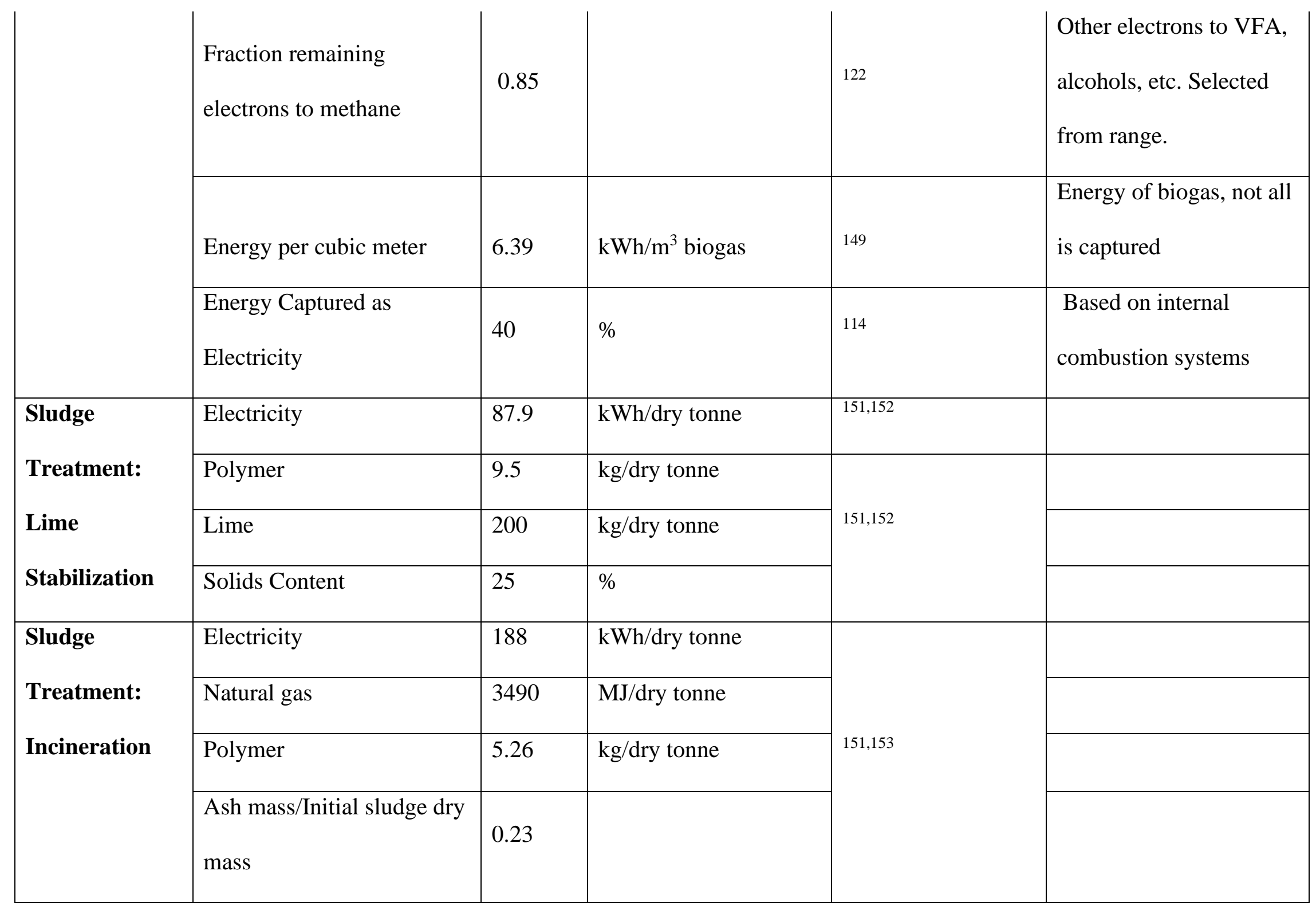




\begin{tabular}{|c|c|c|c|c|c|}
\hline \multirow{4}{*}{$\begin{array}{l}\text { Treatment: } \\
\text { Thermal } \\
\text { Drying }\end{array}$} & Electricity & 242 & $\mathrm{kWh} / \mathrm{dry}$ tonne & \multirow{4}{*}{150,152} & \\
\hline & Natural Gas & 11400 & $\mathrm{MJ} / \mathrm{dry}$ tonne & & \\
\hline & Polymer & 7.83 & $\mathrm{~kg} / \mathrm{dry}$ tonne & & \\
\hline & Solids content & 90 & $\%$ & & \\
\hline \multirow{3}{*}{$\begin{array}{l}\text { Sludge } \\
\text { Treatment: } \\
\text { Composting }\end{array}$} & Electricity & 97.8 & $\mathrm{kWh} /$ dry tonne & \multirow{3}{*}{ 150-152 } & \\
\hline & $\begin{array}{l}\text { Diesel Consumption in } \\
\text { facility }\end{array}$ & 2.83 & $\mathrm{~L} / \mathrm{dry}$ tonne & & \\
\hline & Polymer & 7.33 & $\mathrm{~kg} / \mathrm{dry}$ tonne & & \\
\hline \multirow{2}{*}{$\begin{array}{l}\text { Sludge End of } \\
\text { Life: } \\
\text { Transportation }\end{array}$} & $\begin{array}{l}\text { Distance sludge shipped to } \\
\text { land application }\end{array}$ & 20 & $\mathrm{~km}$ & & $\begin{array}{l}\text { Class } 8 \text { truck, empty } \\
\text { backhaul }\end{array}$ \\
\hline & $\begin{array}{l}\text { Distance sludge shipped to } \\
\text { landfill }\end{array}$ & 52 & $\mathrm{~km}$ & & $\begin{array}{l}\text { Class } 8 \text { truck, empty } \\
\text { backhaul }\end{array}$ \\
\hline \multirow{3}{*}{$\begin{array}{l}\text { Sludge End of } \\
\text { Life: Applying } \\
\text { Compost }\end{array}$} & Diesel Consumption & 2.68 & L/dry tonne & 152 & \\
\hline & $\begin{array}{l}\mathrm{N}_{2} \mathrm{O} \text { emissions from } \\
\text { application }\end{array}$ & 0.316 & $\mathrm{~kg} \mathrm{~N} 2 \mathrm{O} / \mathrm{dry}$ tonne & 152 & \\
\hline & Carbon Sequestered & 250 & $\mathrm{~kg} \mathrm{CO}_{2} \mathrm{e} / \mathrm{dry}$ tonne & 152 & \\
\hline
\end{tabular}




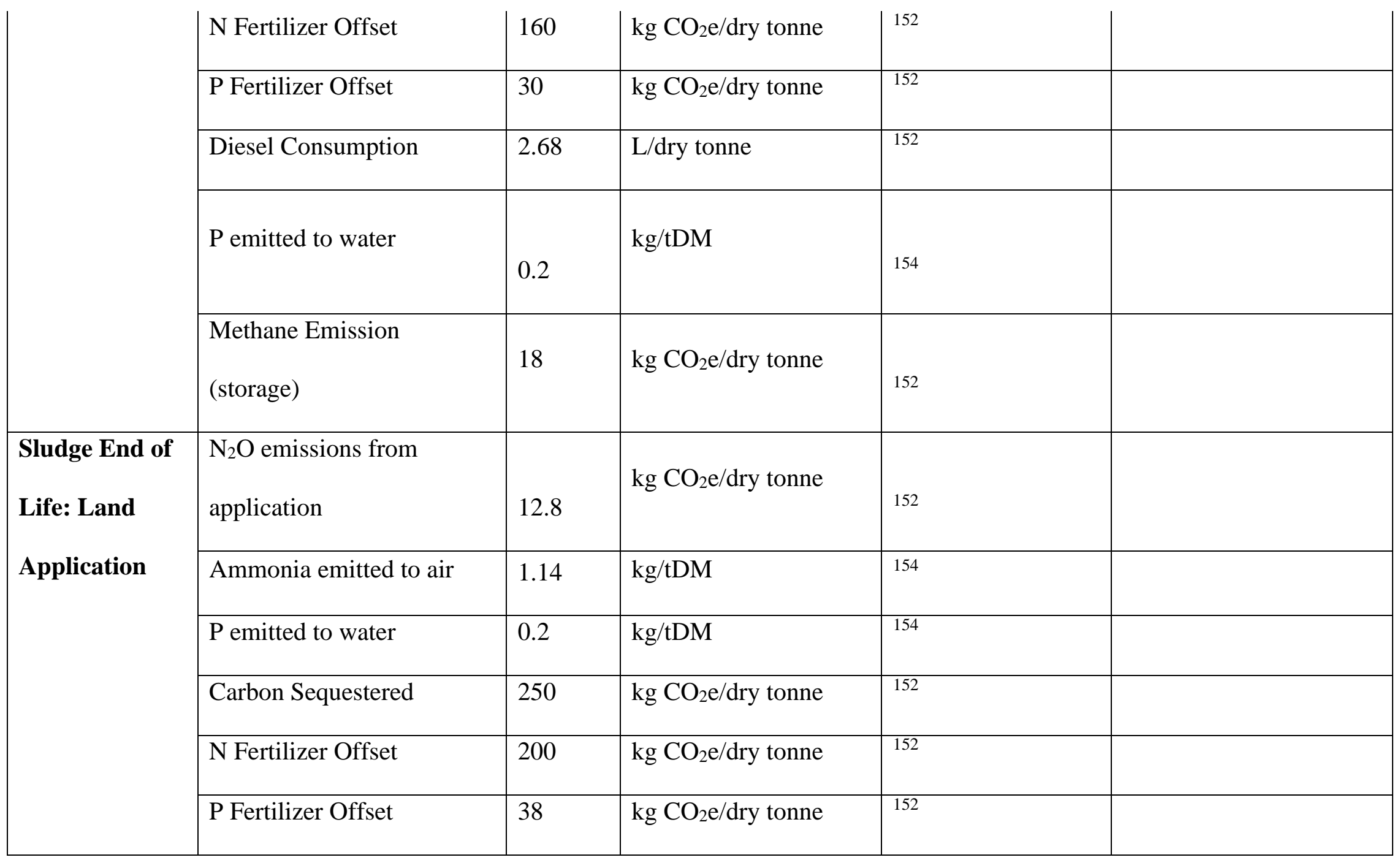




\begin{tabular}{|c|c|c|c|c|c|}
\hline & Methane Emissions & 1060 & $\mathrm{~kg} \mathrm{CO}_{2} \mathrm{e} /$ dry tonne & $78,150-152,154,155$ & $\begin{array}{l}\text { Assuming } 25 \% \text { Fugitive } \\
\text { Emissions. Median value } \\
\text { from these sources. }\end{array}$ \\
\hline \multirow{3}{*}{$\begin{array}{l}\text { Sludge End of } \\
\text { Life: Landfill }\end{array}$} & $\mathrm{N}_{2} \mathrm{O}$ emissions & 292 & $\mathrm{~kg} \mathrm{CO}_{2} \mathrm{e} /$ dry tonne & 152 & \\
\hline & $\mathrm{NH}_{3}$ emitted to air & 3.9 & $\mathrm{~kg} /$ dry tonne & 154 & \\
\hline & Carbon Sequestered & 286 & $\mathrm{~kg} \mathrm{CO}_{2} \mathrm{e} /$ dry tonne & 152 & \\
\hline Synthetic & Distance on Rail & 750 & miles & 156 & \\
\hline Fertilizer & Distance on Barge & 400 & Miles & 156 & \\
\hline Transportation & Distance to Mixer & 50 & miles & 156 & \\
\hline
\end{tabular}




\section{C1 Transporting Materials}

Environmental burdens of hauling materials from the location of production to the municipality were included. Fuel consumption for transportation of all chemicals, activated carbon, biosolids, and urine-derived fertilizer was estimated using equation 21 . All were assumed to be transported with an empty backhaul. This equation was used to account for the distance that synthetic fertilizers were transported via truck, while USLCI data were used for rail and barge transportation. ${ }^{82}$

$F C=\left(F R V \cdot M_{g v}+K\right) \cdot D+\left(F R V \cdot M_{v h}+K\right) \cdot D$

Where: $F C=$ Fuel Consumption, gallons

$F R V=$ Fuel Reduction Value, 0.238 gallons diesel/100 t-mi

$M_{g v}=$ Gross Vehicle Mass, 40 short tons

$M_{v h}=$ Mass of vehicle and trailer, 17.5 short tons

$K=9.7$ gallons $/ 100 \mathrm{mi}$

$D=$ Distance $($ in $100 \mathrm{mi})$

The distance that urine-derived fertilizers and activated carbon were shipped varied between scenarios, while the distance that chemicals were shipped did not. For each scenario, distances urine-derived fertilizers were shipped were estimated by mapping distances from some wastewater treatment plants in the state to large fertilizer suppliers. Assumed distances that chemicals were shipped were informed by the locations of wastewater treatment plants and locations of chemical production plants. These locations were often found using sources such as the NSF Certified Drinking Water Treatment Chemicals database. ${ }^{157}$ 


\section{C2 Household Activities \\ C2.1 Environmental Burdens of Potable Water}

This study differentiated water production in each scenario by considering the ratio of groundwater and surface water. While this is just one of many factors that may affect the environmental impacts of treating potable water, it is useful as a high-level analysis between states. ${ }^{59,158}$ Different LCAs were used to determine the inputs per cubic meter of groundwater and surface water found in Table $10 .^{48,56,65-67,138,57-64}$ This required weighting inputs found in different studies, which will be described below. Then, the inputs of surface and groundwater were applied in the relevant ratios to characterize a composite cubic meter of water. ${ }^{55}$

Some studies on potable water treatment only quantified energy, while others quantified energy and chemicals consumed. Because of this, different weightings were needed for energy and chemical consumption.

For the electricity consumption of surface water, half of the weight was assigned to values reported in the EPRI report because it was a broad survey focused on the U.S., as opposed to focusing on individual water treatment plants. ${ }^{59}$ The electricity consumption in each of the other surface water treatment LCAs was given a weight of $6.25 \% .^{57,61,62,67,138}$ Chemical consumption was based off of the four studies that quantified chemical use. ${ }^{58,60,61,65}$ Each were evenly weighted.

Fewer LCAs on groundwater treatment were found. For electricity consumption, the EPRI report was once again given half of the total weight, ${ }^{59}$ while the remaining sources were each given a weight of $12.5 \% .^{48,58,60,63,64}$ Only three sources contained usable data on chemical consumption. The moderate softening scenario in Godskesen et al. was given a weighting of $20 \%$, the Ishii \& Boyer inventory was given a weighting of $35 \%$ because it assesses water 
treatment in the US, and the inventory in the Renzoni \& Germain study was given a weighting of $45 \%$ because this contained an average value.

\section{C2.2 Water and Acetic Acid for Flushing}

The quantities of water and acetic acid used for flushing are listed in Table 10. Table 11 provides further description of when each type of flush is used. Feces only flushes are estimated to only comprise $2 \%$ of total flushes and are lumped together with urine and feces flushes. ${ }^{87}$

When a user both urinated and defecated, it was assumed that the urine was separated from the feces using a toilet similar to a NoMix toilet. ${ }^{159}$ Because this study assumed urine-diversion is very common, it was assumed that users were used to the concept and used the toilets properly without issues found in early studies on urine diversion. ${ }^{109,160}$ The nutrient composition of urine and feces were obtained from the literature. ${ }^{114,115,117,118}$

Table 11. Description of flush volumes.

\begin{tabular}{|l|l|l|l|}
\hline \multicolumn{2}{|l|}{ Urine Diversion Alternatives } & $\begin{array}{l}\text { Conventional } \\
\text { Alternative }\end{array}$ \\
\hline $\begin{array}{l}\text { 70\% of population diverting } \\
\text { urine }\end{array}$ & $\begin{array}{l}\text { 30\% of } \\
\text { population not } \\
\text { diverting urine }\end{array}$ & Entire Population \\
\hline Urine only & $\begin{array}{l}\text { Urine and } \\
\text { Feces }\end{array}$ & All Flushes & All Flushes \\
\hline UD Flush & $\begin{array}{l}\text { Low-flow flush } \\
+ \text { UD Flush }\end{array}$ & $\begin{array}{l}\text { Low-flow } \\
\text { flush }\end{array}$ & Low-flow flush \\
\hline
\end{tabular}

Acetic acid is needed in both urine diversion alternatives to delay the process of

hydrolysis, which can cause precipitation from urine and can clog pipes. ${ }^{15,28}$ The struvite and ammonium sulfate scenario uses less acetic acid because a higher $\mathrm{pH}$ is needed to precipitate struvite. It was assumed each flush would provide enough acetic acid to neutralize the alkalinity of urine, which is described in equation 22. The $\mathrm{pH}$ of fresh urine is assumed to be $6.2,{ }^{27-29}$ and 
the concentration of ammonia and phosphate were determined from the nutrient composition of urine. It is assumed that nutrients in potable water were negligible compared to urine.

Alkalinity of urine stream $=-\left[\mathrm{H}^{+}\right]+\left[\mathrm{OH}^{-}\right]+\left[\mathrm{NH}_{3}\right]+2\left[\mathrm{PO}_{4}{ }^{3-}\right]$

(Equation 22)

The amount of acetic acid needed for the urine concentration was determined through a pilot scale system at the University of Michigan. It should be noted that this location's potable water has a high $\mathrm{pH}$ of $9.3^{130}$, which may result in an overestimation of how much acetic acid is required.

\section{C3 Conveyance of Urine}

Urine collections is modeled as if it were collected in a pressurized pipe system. The electricity consumption for potable water was deemed as a reasonable estimate. The pipes would be smaller, which would increase head loss. Unlike water, urine collection pipes will not need to be designed to fight fires, reducing required pressure. In addition, they might follow the pathway of sewage collection systems, which already take advantage of gravity.

\section{C4 Urine Derived Fertilizer Production C4.1 Struvite and Ammonium Sulfate}

Struvite is the first fertilizer produced. After the diverted urine arrives at the production center, magnesium oxide is mixed in to provide magnesium and to raise the $\mathrm{pH}$, which causes most of the phosphorus to precipitate as struvite. The precipitated struvite is then dried through draining, an electric dryer, a bucket elevator, and then a vibratory screen (Bott, personal conversation). The effluent from this process continues to ion exchange.

After struvite is precipitated, ion exchange is used to remove the nitrogen and produce a fertilizer. The effluent urine from struvite production is pumped through vessels containing an 
ion exchange resin such as Dowex Mac 3 resin. ${ }^{39,49}$ The ion exchange cartridge collects the ammonia from the urine. ${ }^{39}$ To regenerate a cartridge, $18 \%$ sulfuric acid is pumped through the filter, which extracts the ammonia and produces a liquid ammonium sulfate fertilizer. ${ }^{49} \mathrm{Head}$ loss in the cartridge was estimated using the hydraulic conductivity and common column heights.

It was assumed that each urine-derived fertilizer production facility always had enough ion exchange resin to where nitrogen could be removed for 7 days without exceeding the adsorption capacity. The lifetime of the resin is assumed to be 5 years. ${ }^{49}$ The environmental burdens of ion exchange resin were not available, so polystyrene was used because it the backbone of the resin. ${ }^{161}$

\section{C4.2 Urine Concentration}

The urine concentration scenario removes pharmaceuticals, concentrates urine and deactivates pathogens. While the impacts of pharmaceuticals are not assessed in this study, the inputs for removing them using activated carbon are. The activated carbon is assumed to be shipped back to a regeneration center as a slurry with a $30 \%$ solids concentration. A weighted average for the inputs needed to thermally regenerate activated carbon was determined through

the literature, and it was assumed that $10 \%$ of activated carbon was lost per regeneration. ${ }^{69-72}$ It was assumed that each urine-derived fertilizer plant had enough activated carbon to allow continuous removal of pharmaceuticals for 1.1 years.

Urine is concentrated five times its original concentration using reverse osmosis. It was assumed that the membrane received an acid and alkaline wash every six months. The inputs were obtained from a Hydranautics technical report ${ }^{73}$. The only equipment and maintenance considered were the production of and cleaning of the membrane. The necessary area of 
membrane was based off of the flow rate and the area per influent volume found in other studies. ${ }^{162-164}$ A three year membrane lifetime was assumed.

All urine derived fertilizers were assumed to be transported from the fertilizer production facility to regional fertilizer distributers using class 8 trucks with an empty backhaul. Each trip was assumed to haul 22.5 short tons of fertilizer.

\section{C4.3 Synthetic Fertilizer}

Synthetic fertilizers were used for the conventional alternatives and to ensure all alternatives (including urine diversion) provided the same mass of nitrogen and phosphorus as fertilizer. Equal mass of nutrients was deemed functionally equivalent because previous research

did not find a significant difference in nutrient uptake between these fertilizer alternatives. ${ }^{25,75-77}$ The synthetic fertilizers produced were mono-ammonium phosphate (phosphorous and some nitrogen) and urea (nitrogen). Both are commonly used in the U.S. ${ }^{99}$

The urine concentration alternative retains the most phosphorus, and was used to determine how much phosphorus is needed in each alternative. The struvite and ammonium sulfate alternative retained the most nitrogen, and was used to determine how much urea was needed in the other alternatives.

\section{C5 Sludge Treatment}

Primary sludge is excluded from the scope of this study because it is assumed that urine diversion will not affect the amount produced or how it is treated. This study does model treatment of the sludge produced from biological wastewater treatment and its disposal. 
All secondary sludge is assumed to be thickened, dewatered, and stabilized. In all scenarios, sludge was treated in a combination of anaerobic digestion, composting, lime stabilization, incineration, and thermal drying representative of the state. It is assumed that anaerobic digestion, composting, and lime stabilization produce sludge with $25 \%$ solids. It is assumed that thermally drying results in sludge with $90 \%$ solids. All sources described treating mixed sludge from primary and secondary treatment. Electricity from biogas production in anaerobic digestion is estimated using equation 23 .

$E_{\text {Electricity }}=V S \cdot R_{D, V S} \cdot\left(1-Y_{e, b}\right) \cdot\left(1-Y_{e, v}\right) \cdot P_{b} \cdot E_{\text {biogas }} \cdot e_{\text {electricity }}$ (equation 23)

Where: $E_{\text {Electricity }}=$ Electricity created from biogas, $\mathrm{kWh}$

$V S=\mathrm{kg}$ Volatile Solid produced from wastewater treatment and sent to anaerobic digestion

$$
\begin{aligned}
& R_{D, V S}=\text { Ratio of Volatile Solids destroyed } \\
& Y_{e, b}=\text { Ratio of elections used for biomass production } \\
& Y_{e, v}=\text { Ratio of remaining elections used to produce VFAs and other alcohols } \\
& P_{b}=\text { Production of biogas per kg VS destroyed } \\
& E_{b}=\text { Energy per } \mathrm{m}^{3} \text { of biogas } \\
& e_{\text {electricity }}=\text { Efficiency of converting biogas to electricity }
\end{aligned}
$$

The treated sludge or ash is then shipped to the end of life. The energy use, credits such as fertilizer displacement and carbon sequestration, and emissions to air and water are listed in Table 10. It should be noted that estimates for fugitive methane emissions from landfills varied multiple orders of magnitude. ${ }^{150-152,154,155}$ 


\section{C6 Data Sources for Unit Processes}

Table 12 lists which Life Cycle Databases were used for specific unit processes. GREET was preferably used for electricity and transportation, USLCI was preferably used for other unit processes, and ecoinvent was used in most other cases. Data were not found for some chemicals such as citric acid, so an input-output approach was used in those cases. Data on freshwater use was obtained from Ecoinvent.

Table 12. List of data sources used to quantify environmental impacts.

\begin{tabular}{|l|l|l|l|l|}
\hline Input & Source & Item Name & Unit & Notes \\
\hline Electricity & $\begin{array}{l}\text { EPA eGRID } \\
\text { and GREET }\end{array}$ & & $\begin{array}{l}\mathrm{kWh} \\
\text { eGRID, impact } \\
\text { factors from } \\
\text { GREET }\end{array}$ \\
\hline Natural Gas & USLCI & $\begin{array}{l}\text { Natural gas, combusted in industrial } \\
\text { boiler/US }\end{array}$ & $\mathrm{m}^{3}$ & \\
\hline Urea & ecoinvent & Urea, as N, at Regional Storehouse & $\mathrm{kg} \mathrm{N}$ & \\
\hline $\begin{array}{l}\text { Monoammonium } \\
\text { Phosphate }\end{array}$ & ecoinvent & $\begin{array}{l}\text { Monoammonium phosphate, as } \\
\text { P2O5, at regional storehouse, RER S }\end{array}$ & $\begin{array}{l}\mathrm{kg} \\
\mathrm{Pg} \text { O }\end{array}$ & \\
\hline Acetic acid (98\%) & USLCI & Acetic Acid, at plant/kg/RNA & $\mathrm{kg}$ & \\
\hline Ferric Chloride & ecoinvent & $\begin{array}{l}\text { Iron (III) chloride, 40\% in H2O, at } \\
\text { plant/CH U }\end{array}$ & $\mathrm{kg}$ & \\
\hline Alum & ecoinvent & $\begin{array}{l}\text { Aluminum sulphate, powder, at } \\
\text { plant/RER U }\end{array}$ & $\mathrm{kg}$ & \\
\hline Methanol & USLCI & Methanol, at plant/RNA & $\mathrm{kg}$ & \\
\hline Lime & ecoinvent & Lime, hydraulic, at plant/CH U & $\mathrm{kg}$ & \\
\hline $\begin{array}{l}\text { Sodium } \\
\text { Hypochlorite }\end{array}$ & ecoinvent & $\begin{array}{l}\text { Sodium hypochlorite, 15\% in H2O, } \\
\text { at plant/RER U }\end{array}$ & $\mathrm{kg}$ & \\
\hline $\begin{array}{l}\text { Sodium } \\
\text { hexametaphosphate }\end{array}$ & ecoinvent & Sodium phosphate, at plant/RER U & $\mathrm{kg}$ & \\
\hline $\begin{array}{l}\text { Sodium Silico } \\
\text { Fluoride }\end{array}$ & ecoinvent & $\begin{array}{l}\text { Fluosilicic acid, 22\% in H2O, at } \\
\text { plant/US U }\end{array}$ & $\mathrm{kg}$ & \\
\hline CO 2 & ecoinvent & $\begin{array}{l}\text { Carbon dioxide liquid, at plant/RER } \\
\text { U }\end{array}$ & $\mathrm{kg}$ & \\
\hline Ammonia & USLCI & $\begin{array}{l}\text { Ammonia, steam reforming, liquid, } \\
\text { at plant/RNA }\end{array}$ & $\mathrm{kg}$ & \\
\hline Oxygen & USLCI & Oxygen, liquid, at plant & $\mathrm{kg}$ & \\
\hline Sodium Hydroxide & USLCI & $\begin{array}{l}\text { Sodium hydroxide, production mix, } \\
\text { at plant/RNA }\end{array}$ & $\mathrm{kg}$ & \\
\hline Magnesium Oxide & ecoinvent & Magnesium oxide, at plant/RER U & $\mathrm{kg}$ & \\
\hline
\end{tabular}




\begin{tabular}{|c|c|c|c|c|}
\hline Sulfuric Acid & USLCI & $1 \mathrm{~kg}$ Sulfuric acid, at plant $/ \mathrm{kg} / \mathrm{RNA}$ & $\mathrm{kg}$ & \\
\hline Low-Sulfur Diesel & GREET & & gallon & $\begin{array}{l}\text { Used equation 2- } \\
3 \text { to calculate } \\
\text { diesel } \\
\text { consumption in a } \\
\text { class } 8 \text { truck. }\end{array}$ \\
\hline Barge Transport & USLCI & Transport, barge, diesel powered/US & tkm & \\
\hline Rail Transport & USLCI & Transport, train, diesel powered/US & $\mathrm{tkm}$ & \\
\hline Chlorine Gas & USLCI & $\begin{array}{l}\text { Chlorine, gaseous, prodcution mix, } \\
\text { at plant/RNA }\end{array}$ & $\mathrm{kg}$ & \\
\hline Phosphoric Acid & ecoinvent & $\begin{array}{l}\text { Phosphoric acid, industrial grade, } \\
85 \% \text { in } \mathrm{H} 2 \mathrm{O} \text {, at plant }\end{array}$ & $\mathrm{kg}$ & \\
\hline Sodium Carbonate & ecoinvent & $\begin{array}{l}\text { sodium carbonate from ammonium } \\
\text { chloride production, at plant } / \mathrm{kg} / \mathrm{GLO}\end{array}$ & $\mathrm{kg}$ & \\
\hline $\begin{array}{l}\text { Potassium } \\
\text { Permanganate }\end{array}$ & ecoinvent & $\begin{array}{l}\text { Potassium permanganate, at } \\
\text { plant/RER U }\end{array}$ & $\mathrm{kg}$ & \\
\hline Resin & ecoinvent & $\begin{array}{l}\text { Polystyrene, general purpose, at } \\
\text { pant, CTR/kg/RNA }\end{array}$ & $\mathrm{kg}$ & \\
\hline Fiberglass & ecoinvent & Glass fibre, at plant/RER U & $\mathrm{kg}$ & \\
\hline Activated Carbon & Agrifootprint & $\begin{array}{l}1 \mathrm{~kg} \text { Activated carbon, at plant/RER } \\
\text { Economic }\end{array}$ & $\mathrm{kg}$ & \\
\hline Citric Acid & $\begin{array}{l}\text { USA Input } \\
\text { Output } \\
\text { Database }\end{array}$ & $\begin{array}{l}\text { Other basic organic chemical } \\
\text { manufacturing }\end{array}$ & US \$ & \\
\hline $\begin{array}{l}\text { STPP }(\mathrm{kg}) \text { (sodium } \\
\text { tripolyphosphate }\end{array}$ & ecoinvent & $\begin{array}{l}1 \mathrm{~kg} \text { Sodium tripolyphosphate, at } \\
\text { plant/RER U }\end{array}$ & $\mathrm{kg}$ & \\
\hline Na-DDBS (kg) & $\begin{array}{l}\text { USA Input } \\
\text { Output } \\
\text { Database }\end{array}$ & Soap and other detergents & US \$ & \\
\hline Membrane & ecoinvent & $\begin{array}{l}\text { Polyvinylidenchloride, granulate, at } \\
\text { plant RER U }\end{array}$ & $\mathrm{kg}$ & $\begin{array}{l}\text { PVDF not } \\
\text { available }^{165}\end{array}$ \\
\hline
\end{tabular}

\section{C7 Life Cycle Impact Assessment}

The Life Cycle Impact Assessment was conducted using global warming potential (GWP), cumulative energy demand (CED), freshwater use (Water), eutrophication potential (EP), and acidification potential (AP) as indicators. Freshwater use is technically an inventory approach that is calculated by summing the water utilization and consumption for each unit 
process ${ }^{84}$ Whenever possible, this was measured on Ecoinvent, even if other impacts for a unit process were determined using another database. ${ }^{83}$ This was selected over impact assessment methods such as water deprivation for two main reasons. The first reason is that it would be difficult to determine the origin of all supplies when evaluating multiple states. This would make selection of a water stress index value highly uncertain. The second reason is to allow this framework to be easily applied in other locations. Including an impact method that requires geographic specificity inhibits this research goal. 


\section{APPENDIX D: SCENARIOS MODELED D1 Scenario Description}

The environmental merits and drawbacks of urine diversion will heavily depend on many location specific factors. To evaluate the environmental performance of urine diversion, three diverse locations were modeled as distinct scenarios. In each of these scenarios, all three alternatives were evaluated.

The Vermont scenario highlights the performance of urine diversion in a region with electricity produced from predominately renewable sources, and wastewater treatment plants that remove phosphorus but do not remove nitrogen. This scenario based its wastewater treatment off of a community serving approximately 25,000 residents.

The Michigan scenario considers urine diversion through a broader range of municipalities and has an electricity grid comprised predominately of fossil fuels. This scenario produces an "average" treatment plant by placing the state's treatment plants into four categories and considering the volume of wastewater treated in each. All have strict phosphorus removal standards, while the level of ammonia and nitrogen removal varies between categories.

The Virginia scenario was selected to consider urine diversion in a location with strict nitrogen and phosphorus limits. As many regions look to enact more stringent effluent limits, these plants could benefit the most operationally. This scenario was based off of a treatment plant in the Chesapeake Bay region treating wastewater for 350,000 people.

The scenarios vary factors such as the electricity grid, how water is produced, wastewater effluent limits, sludge treatment and disposal methods, transportation distances, and temperature. 


\section{D2 Electricity Production}

Data on the ratio of fuels used in the electricity grid and the electricity lost in transmission were obtained from EPA eGRID. ${ }^{166}$ The Greenhouse Gases, Regulated Emissions, and Energy Use in Transportation (GREET) Model was then used to determine the net impact of obtaining these fuels, processing these fuels, and combusting them. ${ }^{167}$ The impact per kWh generated is listed in Table 13 .

Table 13. Environmental impacts of electricity production.

\begin{tabular}{|c|c|c|c|c|c|}
\hline & $\begin{array}{l}\text { Global } \\
\text { Warming } \\
\text { Potential }\end{array}$ & $\begin{array}{l}\text { Cumulative } \\
\text { Energy } \\
\text { Demand }\end{array}$ & $\begin{array}{l}\text { Water } \\
\text { Consumption }\end{array}$ & $\begin{array}{l}\text { Eutrophication } \\
\text { Potential }\end{array}$ & $\begin{array}{l}\text { Acidification } \\
\text { Potential }\end{array}$ \\
\hline Scenario & $\begin{array}{l}\mathrm{kg} \mathrm{CO}^{2-} \\
\mathrm{eq} / \mathrm{kWh}\end{array}$ & $\mathrm{MJ} / \mathrm{kWh}$ & $\mathrm{m}^{3} / \mathrm{kWh}$ & kg N-eq/kWh & $\begin{array}{l}\mathrm{kg} \mathrm{SO}_{2^{-}} \\
\mathrm{eq} / \mathrm{kWh}\end{array}$ \\
\hline Vermont & 0.107 & 6.45 & $7.68 \cdot 10^{-5}$ & $1.04 \cdot 10^{-5}$ & $2.96 \cdot 10^{-4}$ \\
\hline Michigan & 0.544 & 8.08 & $1.54 \cdot 10^{-4}$ & $1.70 \cdot 10^{-5}$ & $1.26 \cdot 10^{-3}$ \\
\hline Virginia & 0.450 & 8.14 & $1.42 \cdot 10^{-3}$ & $1.74 \cdot 10^{-5}$ & $8.02 \cdot 10^{-4}$ \\
\hline
\end{tabular}

\section{D3 Water Sources}

Table 14 shows the ratio of surface and groundwater used in the public supply for each state.$^{55}$ This ratio was multiplied by the inputs for each type of water source for a composite cubic meter of water.

Table 14. Sources of Potable Water by Location.

Percentages used with the potable water inventories to create water inventories in each scenario.

\begin{tabular}{|l|l|l|l|}
\hline Water Source & Michigan & Vermont & Virginia \\
\hline Surface Water & $81 \%$ & $63 \%$ & $88 \%$ \\
\hline Groundwater & $19 \%$ & $37 \%$ & $12 \%$ \\
\hline
\end{tabular}

\section{D4 Wastewater Treatment}


Effluent standards for each scenario were determined through assessing technical reports from each state considered. ${ }^{168}$ These effluent standards are shown in Table 15. The Virginia and Vermont scenarios focused on one type of treatment plant, while the Michigan scenario evaluated the treatment plants in the state to make an "average" treatment plant. Relevant real wastewater treatment plants were used to select the numbers of basins, solid retention time, MLSS concentration, and secondary clarifier area.

\section{Table 15. Effluent Wastewater Standard for input in Each Location.} All constituents are listed in milligrams per liter.

* Treatment plants with denitrification had a nitrate limit of 3 milligrams of nitrate- $N$ per liter. ** Treatment plants with nitrification had an ammonia limit 8 milligrams of ammonia-N per liter.

\begin{tabular}{|l|l|l|l|}
\hline Components & Michigan & Vermont & Virginia \\
\hline BOD5 & 25 & 25 & 5 \\
\hline TSS & 30 & 20 & 6 \\
\hline Nitrate-N & $-*$ & - & 3 \\
\hline Ammonia-N & $-* *$ & - & 1 \\
\hline TP & 0.7 & 0.2 & 0.18 \\
\hline
\end{tabular}

In the Vermont scenario, the Rutland wastewater treatment plant was modeled, which has an aerobic zone for COD removal and adds ferric chloride to remove phosphorus.

The Michigan scenario produced an "average" treatment plant from the approximately 400 in Michigan. ${ }^{168}$ The treatment plants were put in four categories. Table 16 lists what percent each category treats, which was based on total volume. Both Large-sized wastewater treatment plants and Small-sized treatment plants do not use nitrification or denitrification to remove nitrogen. Some medium-sized treatment plants use nitrification to reduce ammonia, while others use nitrification and denitrification to reduce total nitrogen. All treatment plants are assumed to remove phosphorus, usually with ferric chloride precipitation. Parameters from the Detroit Wastewater treatment plant were used to model the large wastewater treatment plant. The 
Downriver wastewater treatment plant was selected to represent the medium sized treatment centers without denitrification. The Ann Arbor wastewater treatment plant was used to represent the medium-sized treatment plant with denitrification. The small wastewater treatment plants were represented by the Pontiac treatment plant.

Table 16. Description of WWTPs in Michigan.

The four types of wastewater treatment plants that are modeled to make the average Michigan treatment plant. The percentage is determined by the volume of wastewater treated.

\begin{tabular}{|l|l|l|l|}
\hline Categories & $\begin{array}{l}\text { Percent } \\
\text { of Total }\end{array}$ & $\begin{array}{l}\text { Volume } \\
\text { treated } \\
\text { per day } \\
\text { (MGD) }\end{array}$ & Secondary treatment configuration \\
\hline Large-sized WWTP & 46 & $>100$ & $\begin{array}{l}\text { Single aerobic zone with short SRT and chemical } \\
\text { addition for phosphorus removal }\end{array}$ \\
\hline $\begin{array}{l}\text { Medium-sized } \\
\text { WWTPs without } \\
\text { denitrification }\end{array}$ & 28.8 & $10-100$ & $\begin{array}{l}\text { Single aerobic zone with long SRT for nitrification and } \\
\text { chemical addition for phosphorus removal }\end{array}$ \\
\hline $\begin{array}{l}\text { Medium-sized } \\
\text { WWTPs with } \\
\text { denitrification }\end{array}$ & 4.2 & $10-100$ & $\begin{array}{l}\text { A2O(Anaerobic+Anoxic+Aerobic) process and } \\
\text { chemical addition for phosphorus removal }\end{array}$ \\
\hline Small sized WWTPs & 21 & $<10$ & $\begin{array}{l}\text { Single aerobic zone with short SRT and chemical } \\
\text { addition for phosphorus removal }\end{array}$ \\
\hline
\end{tabular}

The treatment plant modeled for the Virginia scenario represented a plant near the Chesapeake Bay estuary, which is sensitive to eutrophication. ${ }^{169}$ The Alexandria wastewater treatment plant is located in the eutrophication sensitive Chesapeake Bay estuary and was used to model this scenario. This treatment plant has a 5-Stage Bardenpho configuration.

\section{D5 Sludge Treatment and Disposal}

Table 17 displays the ratio of sludge stabilization methods used in each scenario ${ }^{170-173}$. The methods used to dispose of these treated biosolids are listed in Table 18. 
Table 17. Sludge Treatment Methods used in each Scenario.

*Due to a very low percent of aerobic digestion, this was included with anaerobic digestion.

\begin{tabular}{|l|l|l|l|}
\hline Treatment Process & Michigan & Vermont & Virginia \\
\hline Anaerobic Digestion* & $11 \%$ & $23.7 \%$ & $47.8 \%$ \\
\hline Lime Stabilization & $44.5 \%$ & $42.9 \%$ & $11.4 \%$ \\
\hline Incineration & $11.5 \%$ & $1.6 \%$ & $40.1 \%$ \\
\hline Thermal Drying & $33 \%$ & $0 \%$ & $0.667 \%$ \\
\hline Compost & $0 \%$ & $31.8 \%$ & $0 \%$ \\
\hline
\end{tabular}

Table 18. End of life for biosolids in each scenario.

\begin{tabular}{|l|l|l|l|}
\hline Treatment & $\begin{array}{l}\text { Michiga } \\
\text { n }\end{array}$ & Vermont & Virginia \\
\hline $\begin{array}{l}\text { Land Applied }(25 \% \\
\text { solids) }\end{array}$ & $23.5 \%$ & $48.2 \%$ & $28.7 \%$ \\
\hline $\begin{array}{l}\text { Land applied (90\% } \\
\text { solids) }\end{array}$ & $33.0 \%$ & $0 \%$ & $0.67 \%$ \\
\hline $\begin{array}{l}\text { Landfilled (25\% } \\
\text { solids) }\end{array}$ & $32.0 \%$ & $50.2 \%$ & $30.5 \%$ \\
\hline Incinerated & $11.5 \%$ & $1.60 \%$ & $40.1 \%$ \\
\hline
\end{tabular}

\section{D6 Transportation Distances}

Table 19 lists the distances required to transport urine derived fertilizers and activated carbon for each scenario. Google Maps was used to determine the distance between the wastewater treatment plant and the end location. The wastewater treatment plant was selected because it was assumed that the urine derived fertilizer production plant was located near the wastewater treatment plant. For urine derived fertilizers, the distance to the two closest largescale fertilizer distributors was quantified and averaged to account for the possibility that a fertilizer distributor would not accept all of the fertilizer produced. 
Table 19. Shipping distances in different scenarios. All distances are in kilometers.

\begin{tabular}{|l|l|l|l|}
\hline Material & Vermont & Michigan & Virginia \\
\hline $\begin{array}{l}\text { Activated } \\
\text { Carbon }\end{array}$ & 500 & 350 & 425 \\
\hline Fertilizer & 28.4 & 17.7 & 63.2 \\
\hline
\end{tabular}




\section{APPENDIX E: SENSITIVITY ANALYSIS}

Sensitivity analyses were used to assess the robustness of the results, to expand the results beyond three specific cases, and to test the uncertainty due to the parameters and choices selected for each scenario. Figure 6 shows the 12 simulation scenarios evaluated using a Monte Carlo with 10,000 repetitions. The important parameters were determined using a one-at-a-time sensitivity analysis. Some parameters that were correlated, such as TSS removal and BOD removal during primary clarification, were then linked. Data on each parameter were collected in order to determine a probability distribution. In cases where there were few data points or these systems are only in early stages of development (e.g. urine collection systems), a conservative approach was used and either triangular or uniform distributions were used. All distributions are listed in Table 20, and some are discussed afterwards.
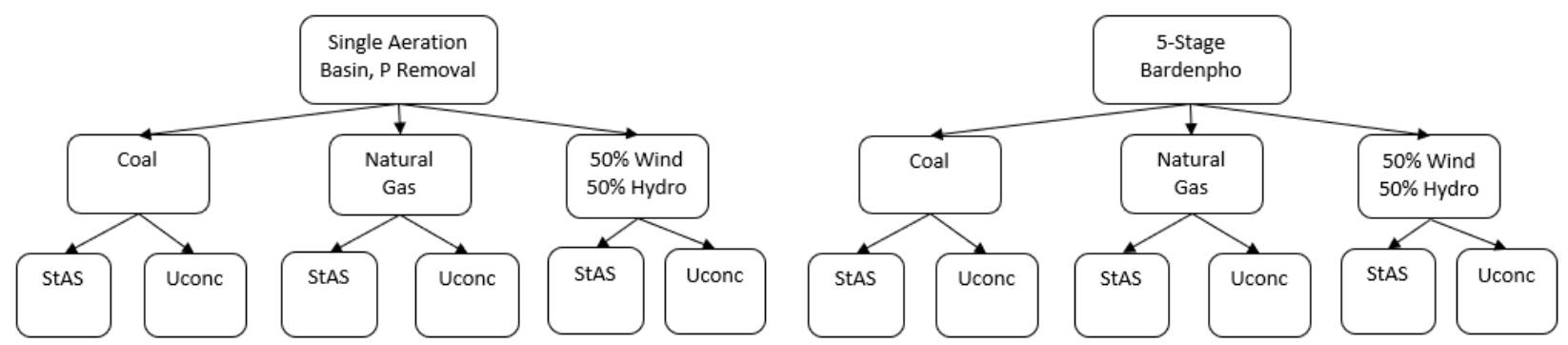

Figure 6. Depiction of simulations ran in sensitivity analysis.

Each of the 12 boxes at the bottom indicate an individual Monte Carlo with 10,000 repetitions. StAS stands for Struvite and Ammonium Sulfate and Uconc stands for Urine Concentration. 
Table 20. List of distributions for parameters in the Monte Carlo analysis.

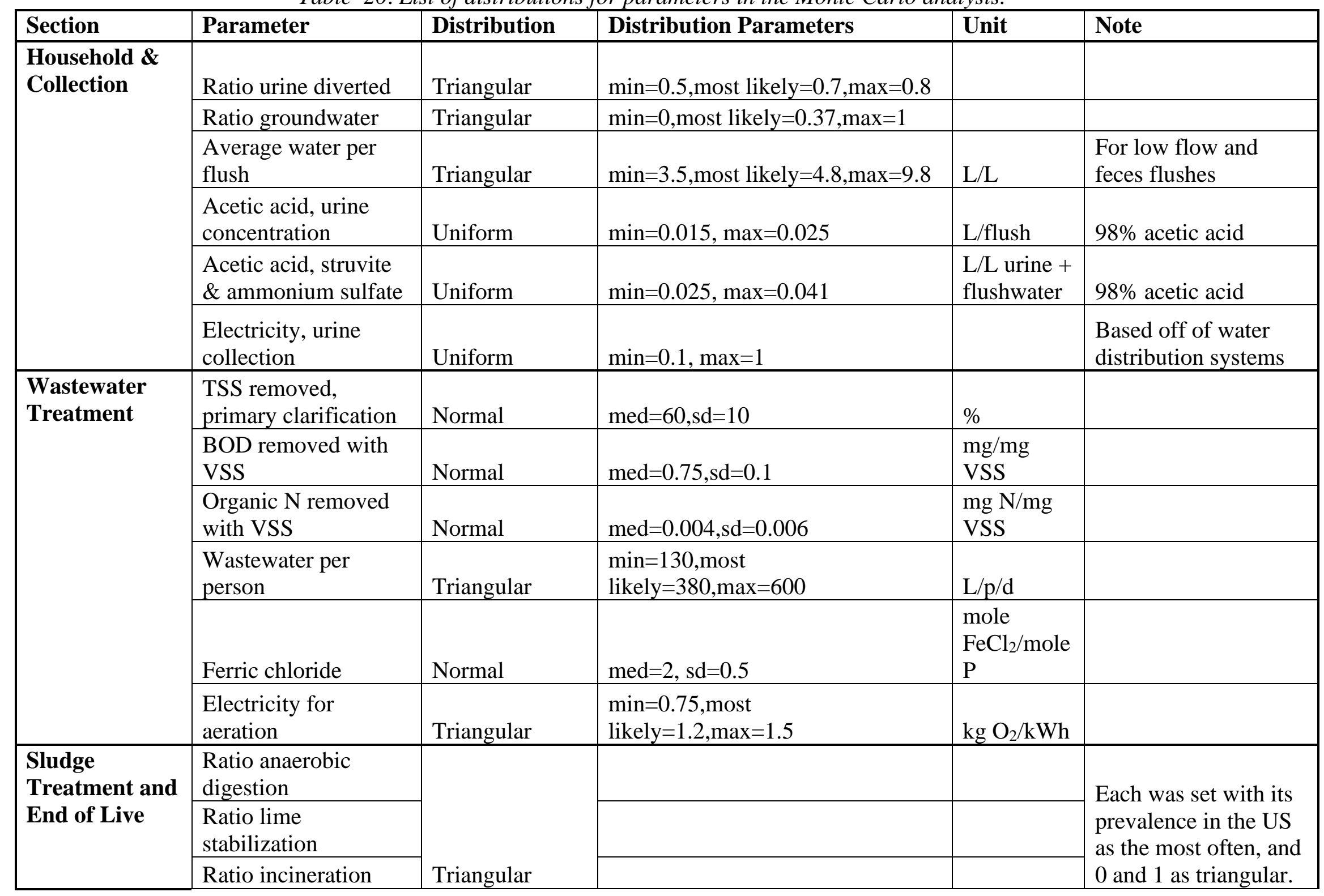




\begin{tabular}{|c|c|c|c|c|}
\hline & Ratio drying & & & \multirow{2}{*}{$\begin{array}{l}\text { These were scaled to } \\
\text { equal } 1 .{ }^{174}\end{array}$} \\
\hline & \multicolumn{2}{|l|}{ Ratio composting } & & \\
\hline & $\begin{array}{l}\text { Land applied, 25\% } \\
\text { solid }\end{array}$ & & & \multirow{2}{*}{$\begin{array}{l}\text { Ratio of these two } \\
\text { types of sludge } \\
\text { treatment. Max=ratio } \\
\text { of land applied- } \\
\text { thermally dried to } \\
\text { ratio landfilled. Other } \\
\text { end of life determined } \\
\text { by treatment } \\
\text { method. } .^{174}\end{array}$} \\
\hline & Landfilled & Triangular & & \\
\hline \multirow{3}{*}{$\begin{array}{l}\text { Struvite \& } \\
\text { Ammonium } \\
\text { Sulfate }\end{array}$} & $\begin{array}{l}\text { Struvite } \mathrm{P} \text { recovery } \\
\text { ratio }\end{array}$ & Triangular & $\begin{array}{l}\min =0.9, \text { most } \\
\text { likely }=0.96, \max =0.99\end{array}$ & \\
\hline & $\begin{array}{l}\text { Ion exchange } \mathrm{N} \\
\text { recovery }\end{array}$ & Uniform & $\min =0.93, \max =0.99$ & \\
\hline & $\begin{array}{l}\text { Ion exchange } \\
\text { stoichiometric ratio }\end{array}$ & Triangular & $\begin{array}{l}\min =0.71, \text { most } \\
\text { likely }=0.91, \max =0.98\end{array}$ & $\begin{array}{l}1 \text { indicates every } \\
\text { mole of sulfate binds } \\
\text { with ammonium. } \\
\text { Performance often } \\
\text { increases as systems } \\
\text { continue to be } \\
\text { developed. Weak } \\
\text { Acid Cation } \\
\text { Exchange systems } \\
\text { often said to operate } \\
\text { near } 100 \% \text { efficiency. }\end{array}$ \\
\hline \multirow{3}{*}{$\begin{array}{l}\text { Urine } \\
\text { Concentration }\end{array}$} & Uconc $\mathrm{N}$ recovery & Uniform & $\min =0.91, \max =0.99$ & \\
\hline & Uconc $\mathrm{P}$ recovery & Uniform & $\min =0.98, \max =1$ & \\
\hline & Uconc COD recovery & Uniform & $\min =0.95, \max =0.99$ & \\
\hline
\end{tabular}




\begin{tabular}{|c|c|c|c|c|c|}
\hline & $\begin{array}{l}\text { Uconc electricity } \\
\text { consumption }\end{array}$ & Triangular Beta & $\begin{array}{l}\min =0.002, \text { most } \\
\text { likely }=0.0035, \max =0.036\end{array}$ & $\begin{array}{l}\mathrm{kWh} / \mathrm{L} \\
\text { permeate } \\
\text { removed }\end{array}$ & $\begin{array}{l}\text { Based off of small } \\
\text { scale desalination } \\
\text { reverse osmosis } \\
\text { systems with Energy } \\
\text { Recovery Devices. }\end{array}$ \\
\hline \multirow[t]{2}{*}{$\begin{array}{l}\text { Fertilizer } \\
\text { Transportation }\end{array}$} & $\begin{array}{l}\text { Ratio synthetic } \\
\text { fertilizer sent by } \\
\text { truck }\end{array}$ & Triangular & $\begin{array}{l}\min =0.015, \text { most } \\
\text { likely }=0.78, \max =0.22, \text { shape }=6\end{array}$ & & $\begin{array}{l}\text { Remaining trip } 2 / 3 \text { on } \\
\text { rail, } 1 / 3 \text { on barge. } \\
\text { From different } \\
\text { fertilizer types. }\end{array}$ \\
\hline & $\begin{array}{l}\text { Distance UD is } \\
\text { shipped }\end{array}$ & $\begin{array}{l}\text { Truncated } \\
\text { lognormal }\end{array}$ & median $=85, \mathrm{sd}=75, \min =5, \max =500$ & $\mathrm{~km}$ & $\begin{array}{l}\text { Determined from } \\
\text { Google Maps } \\
\text { searches, }{ }^{176} \text { Trimmer } \\
\text { and Guest, }{ }^{100} \text { and US } \\
\text { city size statistics. All } \\
\text { via truck. }\end{array}$ \\
\hline
\end{tabular}


Ion exchange stoichiometric ratio

The amount of sulfuric acid used to regenerate ion exchange resin was one of the most important parameters for the struvite and ammonium sulfate alternative. The stoichiometric ratio is how many ions of sulfuric acid are needed relative to the amount of ammonium ions removed. A weak acid cation exchange resin is used, which are said to often operate near $100 \%$ efficiency. The data used in the study are from small-scale experiments, and have a much lower efficiency. The triangular distribution selected assumes that efficiency will improve as the practice becomes more common.

Urine concentration electricity

The electricity demand from reverse osmosis was one of the most important parameters for the urine concentration alternative. The study used a small-scale system for electricity consumption. The Monte Carlo evaluated small-scale desalination systems with energy recovery devices to evaluate how energy intensive reverse osmosis may be at this scale. Desalination was selected as a proxy because much data are available and ocean water has a higher total dissolved solids than urine.

Distance urine is shipped

The probability distribution for distances urine is shipped were estimated by the amount of people in certain sized cities and relevant distances for each. Distances in cities with less than 500,000 were estimated using Google Maps searches. Distances found in Trimmer and Guest ${ }^{100}$ were used to estimate distances from larger cities. All transportation was assumed to be via truck, though it is certainly possible that larger cities could use trains. 


\section{APPENDIX F: SUPPLEMENTAL RESULTS}

More information on the results are shown below. The first section contains graphs comparing the three alternatives in Vermont (Figure 7) and Michigan (Figure 8). The next section has graphs showing each impact measured per component in all scenarios and alternatives (Figures 9-22). Figure 23 then compares different methodologies for estimating the changes in wastewater treatment due to urine diversion.

\section{F1 Comparison of Alternatives}

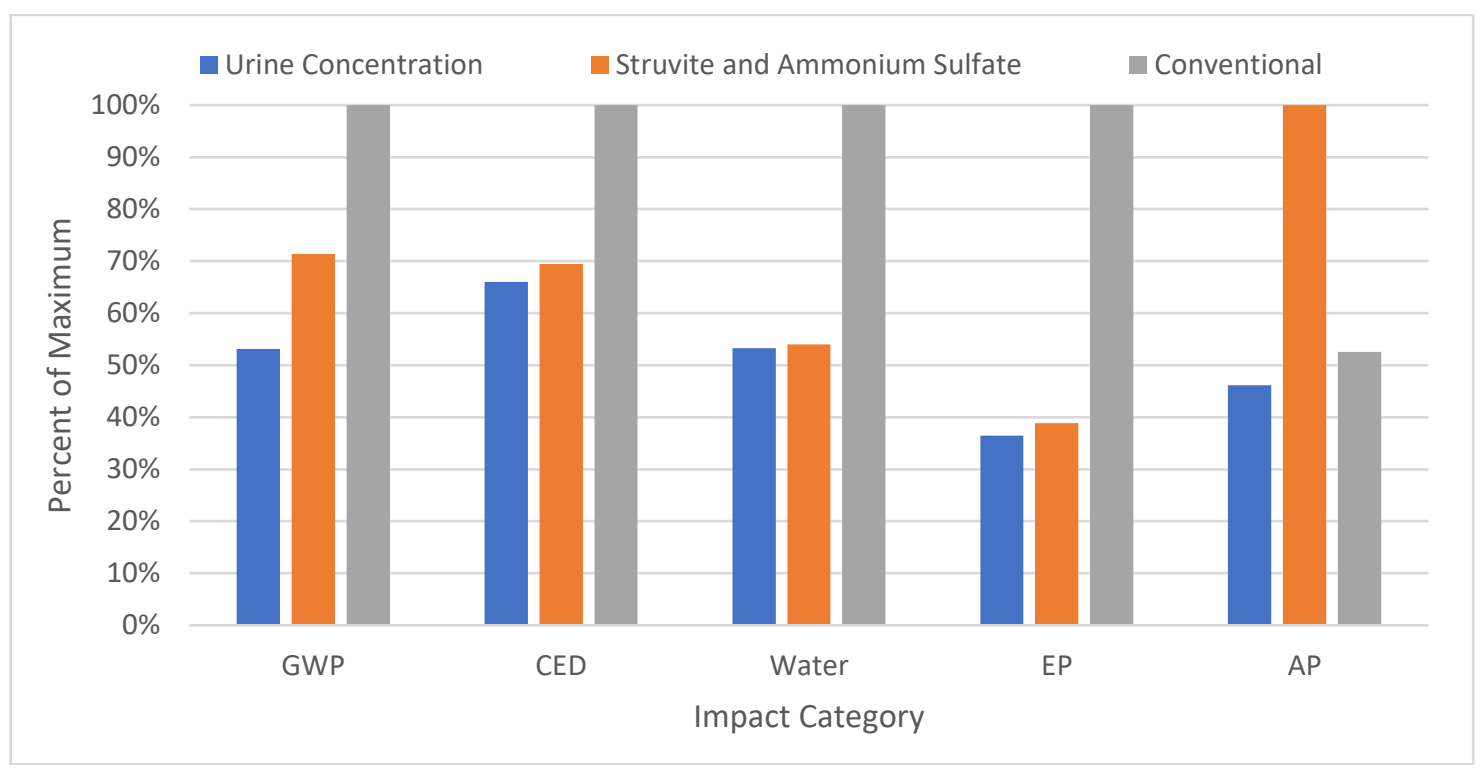

Figure 7. Normalized Impacts in Vermont Scenario.

Total impacts in each alternative normalized to the maximum value. 


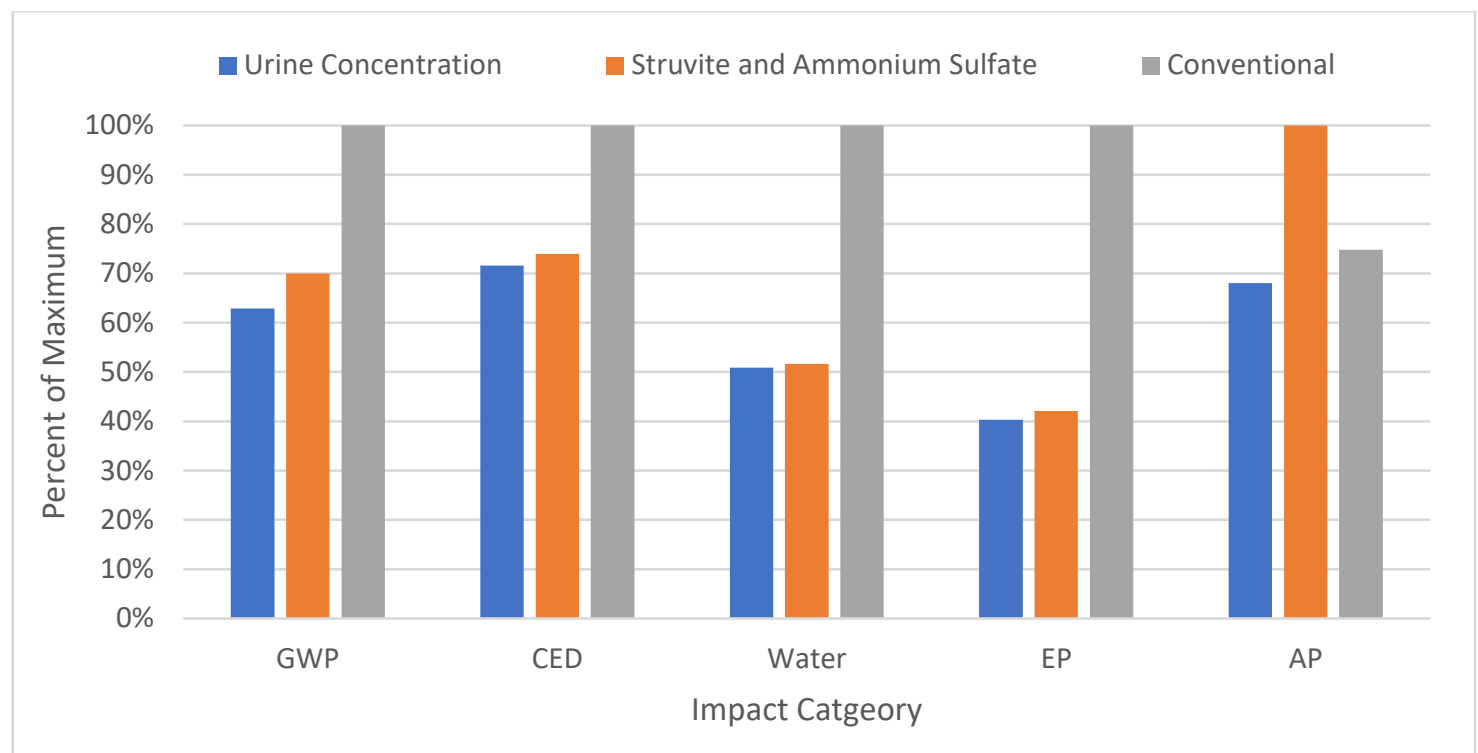

Figure 8. Normalized Impacts in Michigan Scenario.

Total impacts in each alternative normalized to the maximum value.

\section{F2 Impacts per Component}

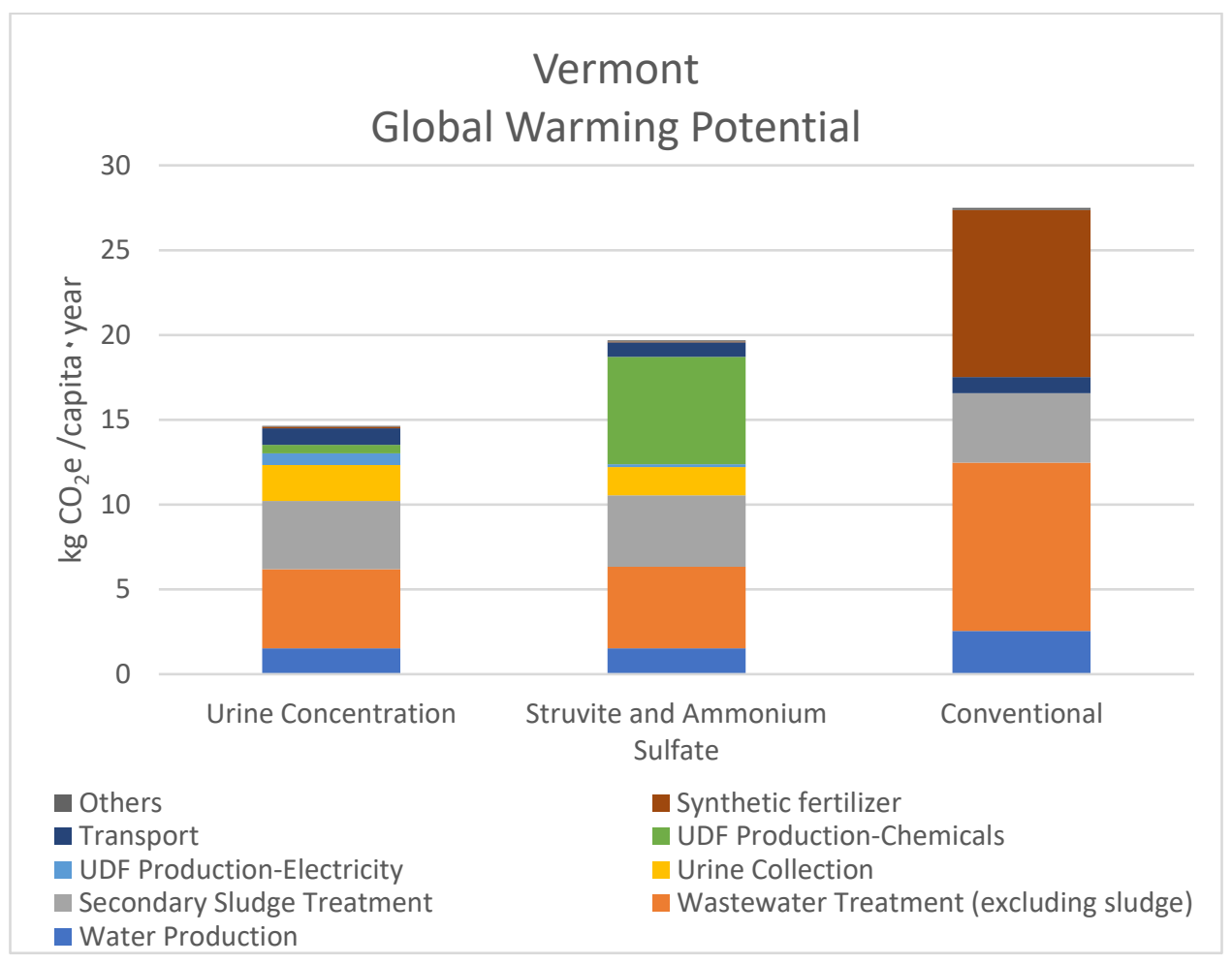

Figure 9. GWP of the Vermont alternatives by Process. 


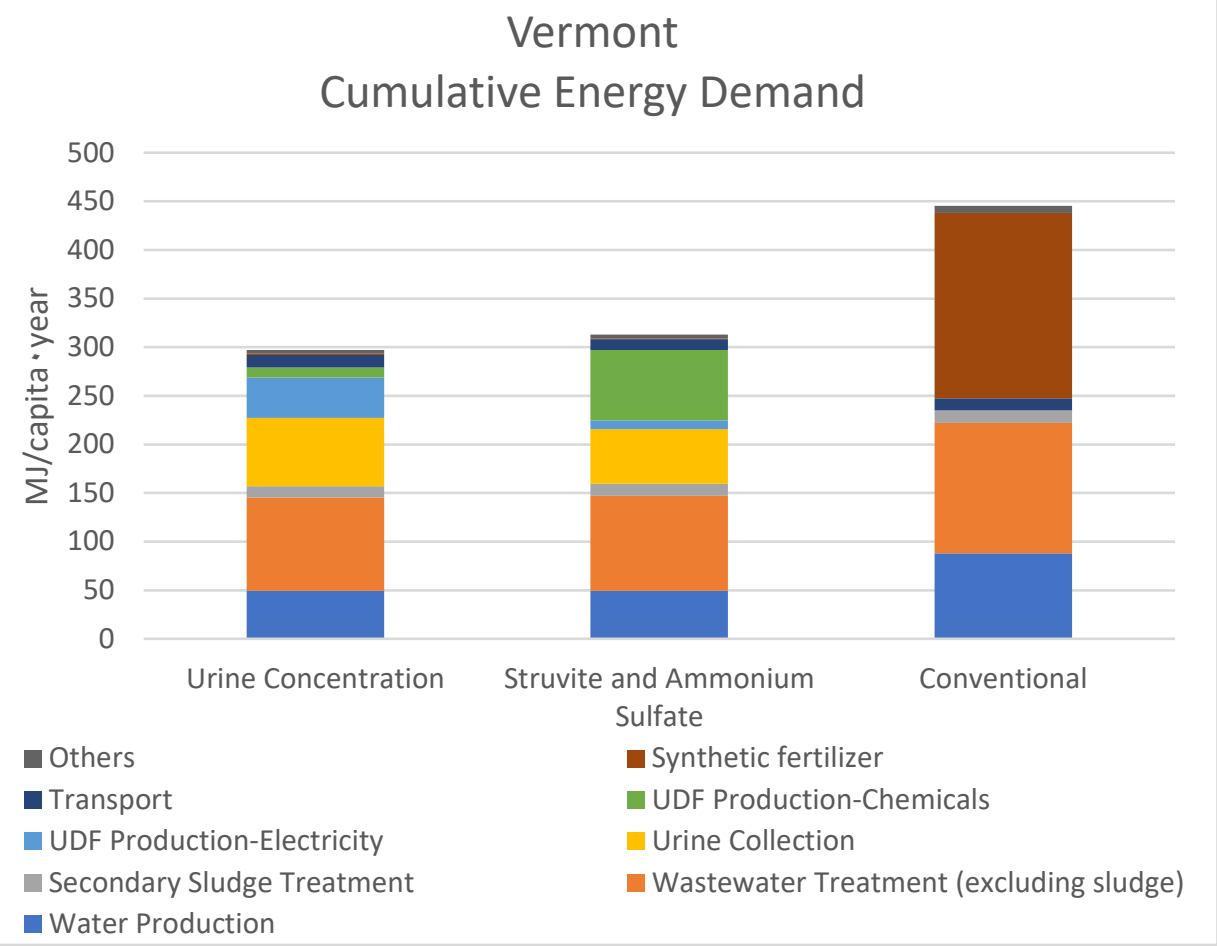

Figure 10. CED of the Vermont alternatives by Process.

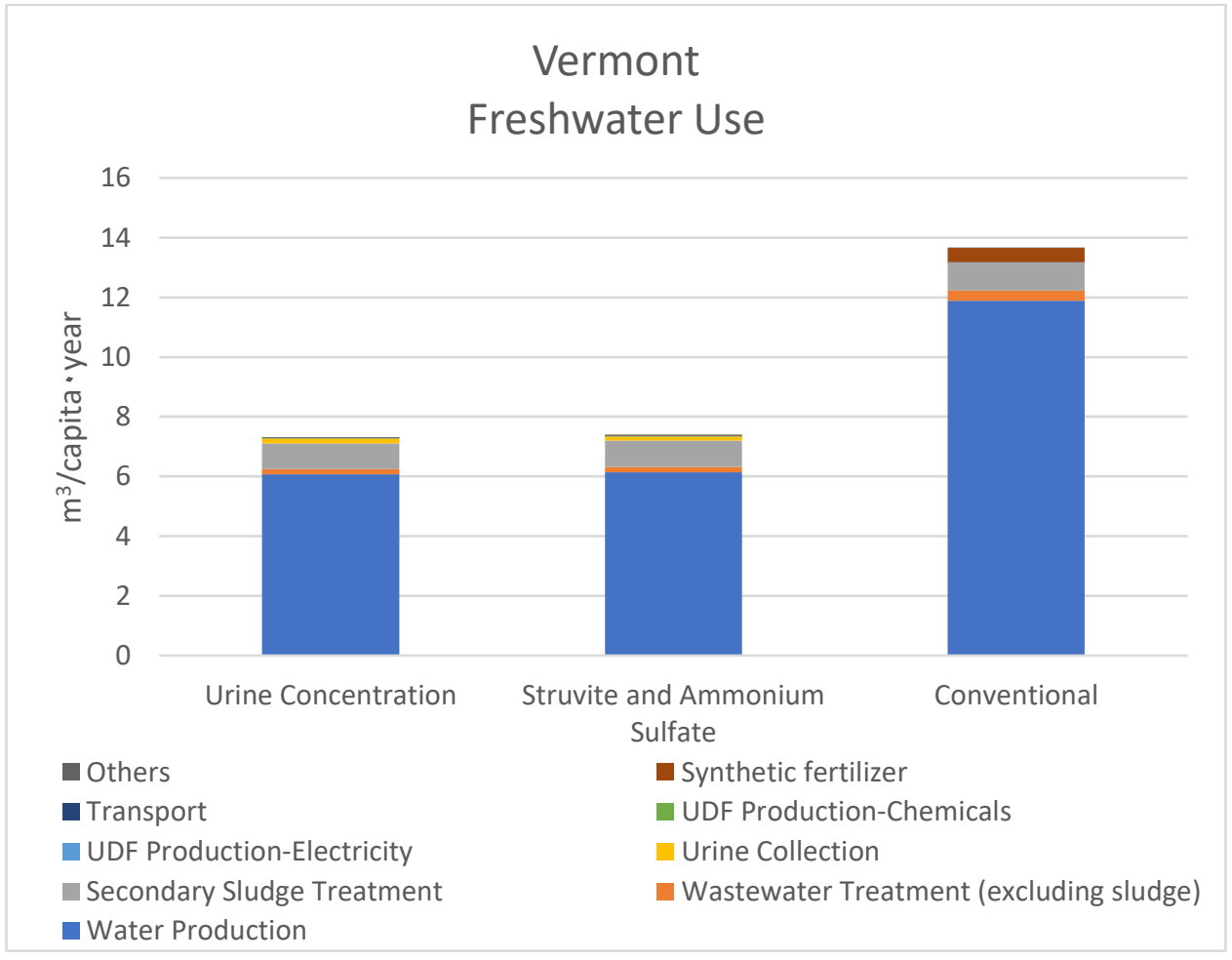

Figure 11. Freshwater use of the Vermont alternatives by Process. 


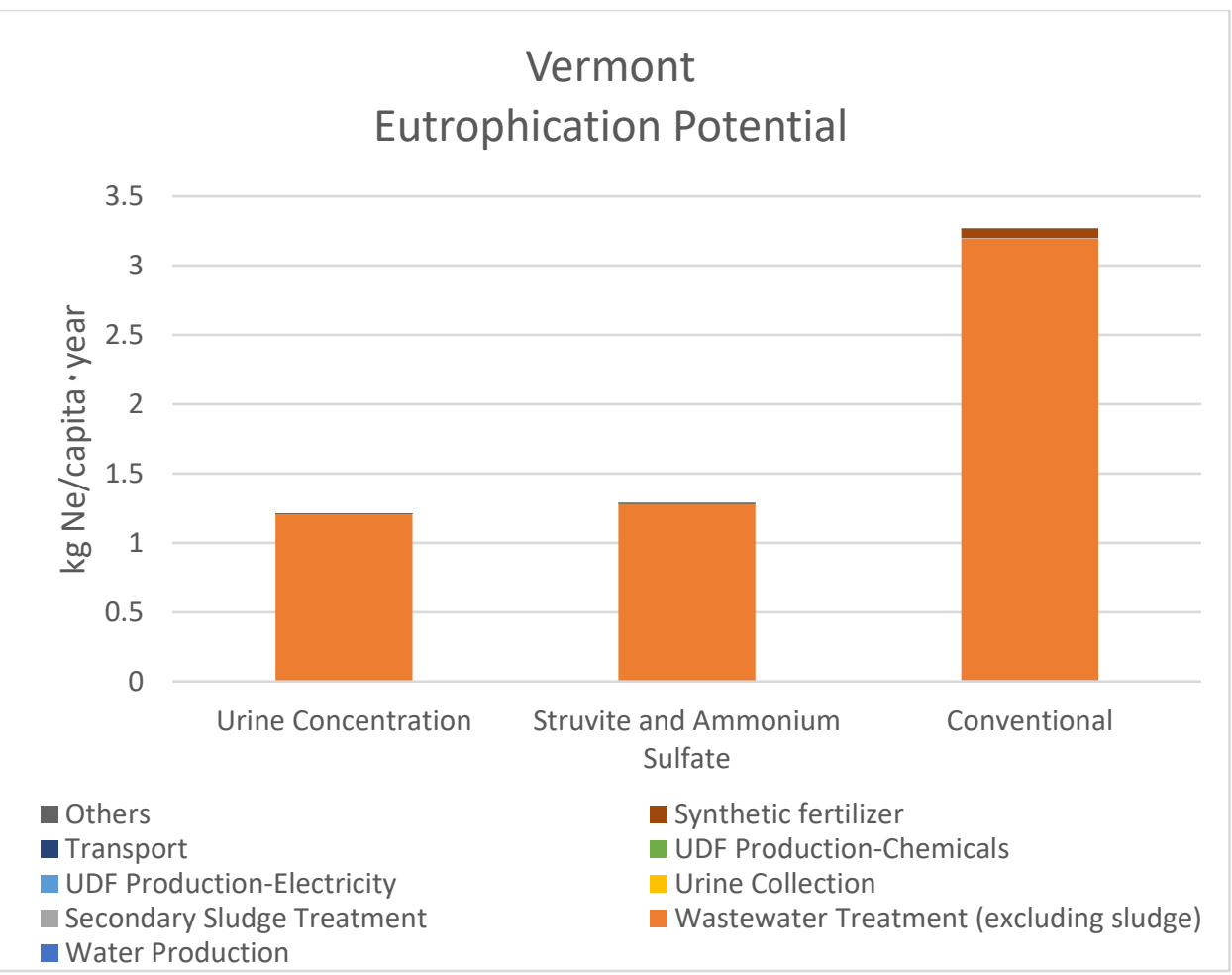

Figure 12. Eutrophication potential of the Vermont alternatives by Process.

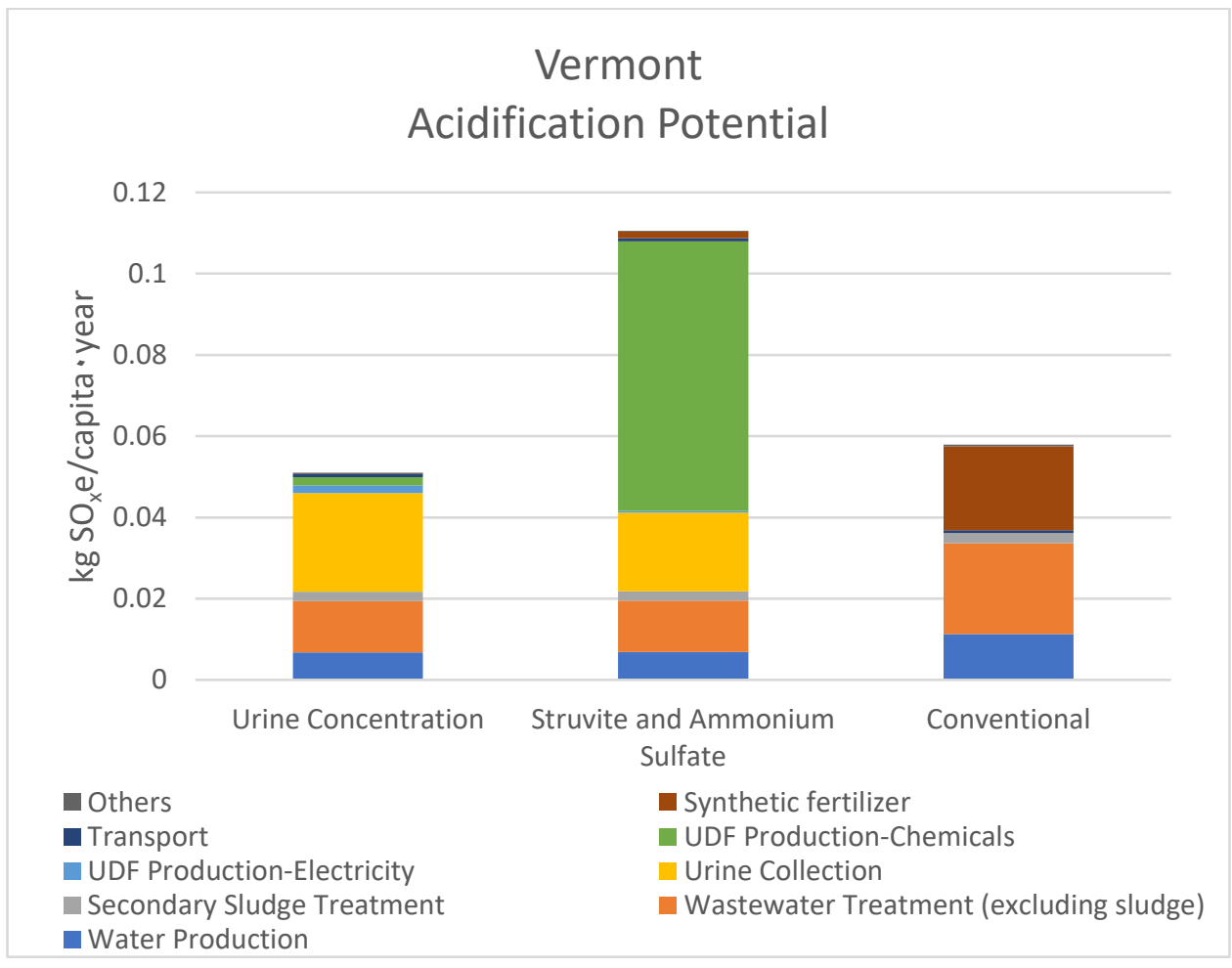

Figure 13. Acidification potential of the Vermont alternatives by Process. 


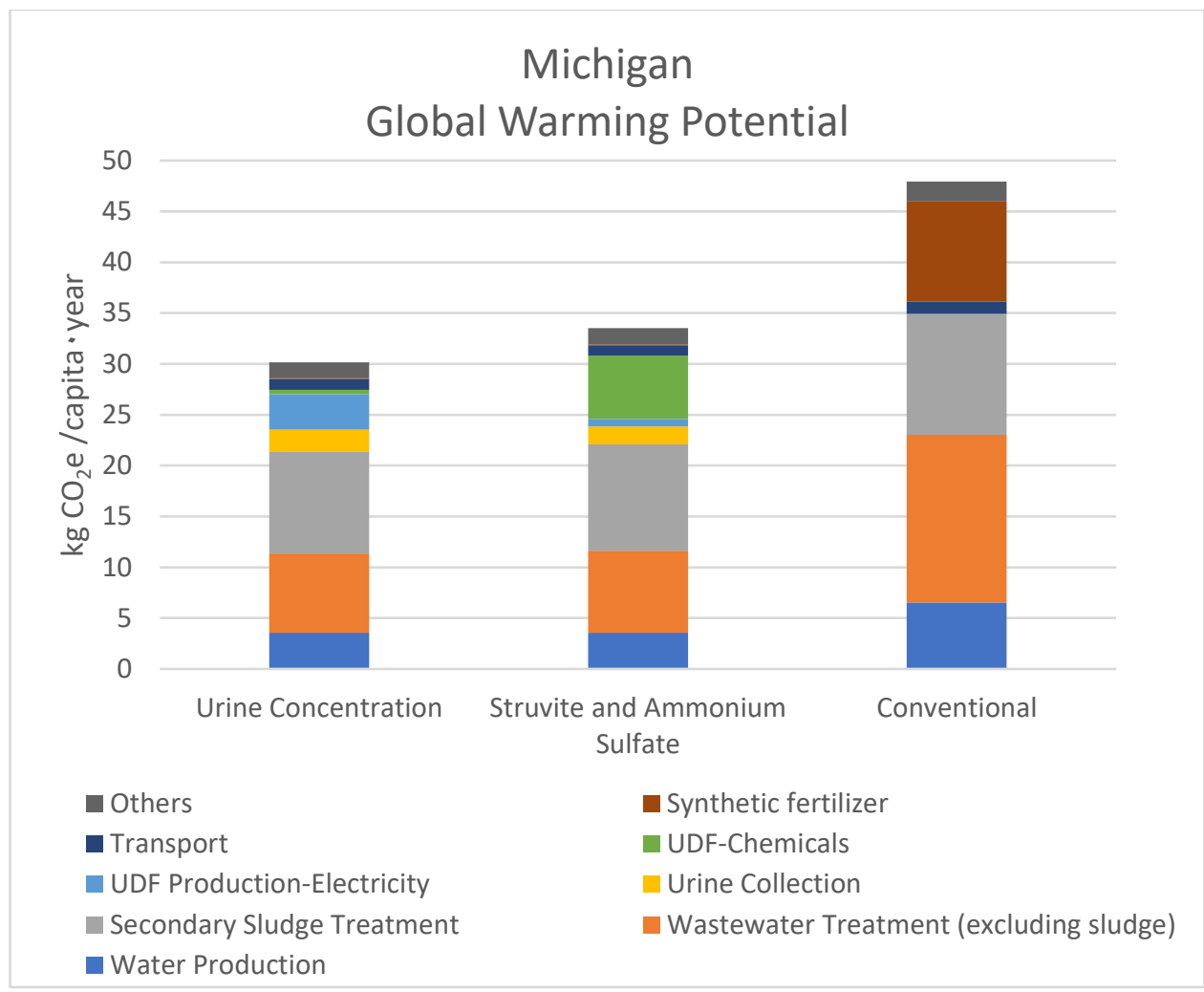

Figure 14. GWP of the Michigan alternatives by Process.

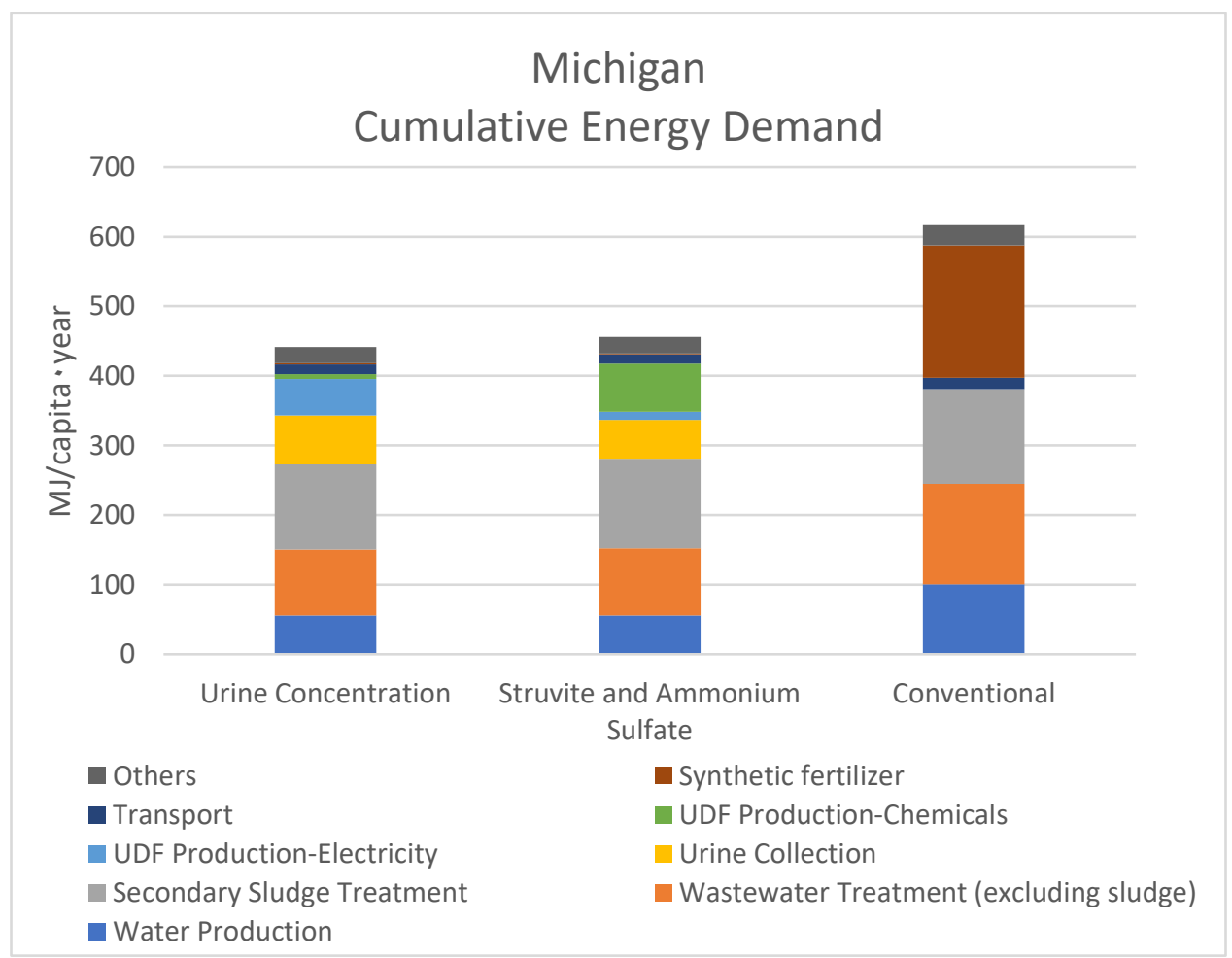

Figure 15. CED of the Michigan alternatives by Process. 


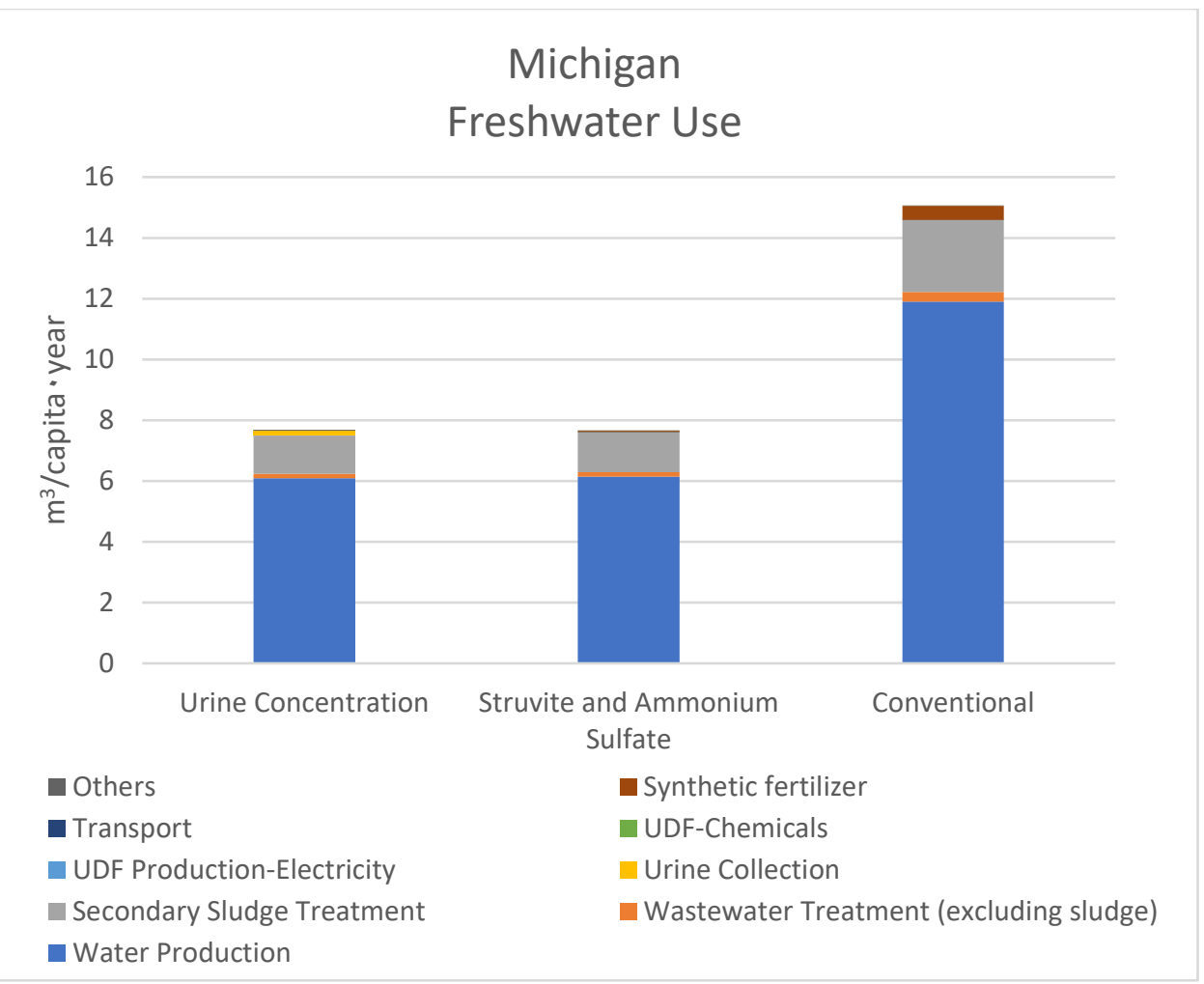

Figure 16. Freshwater use of the Michigan alternatives by Process. 


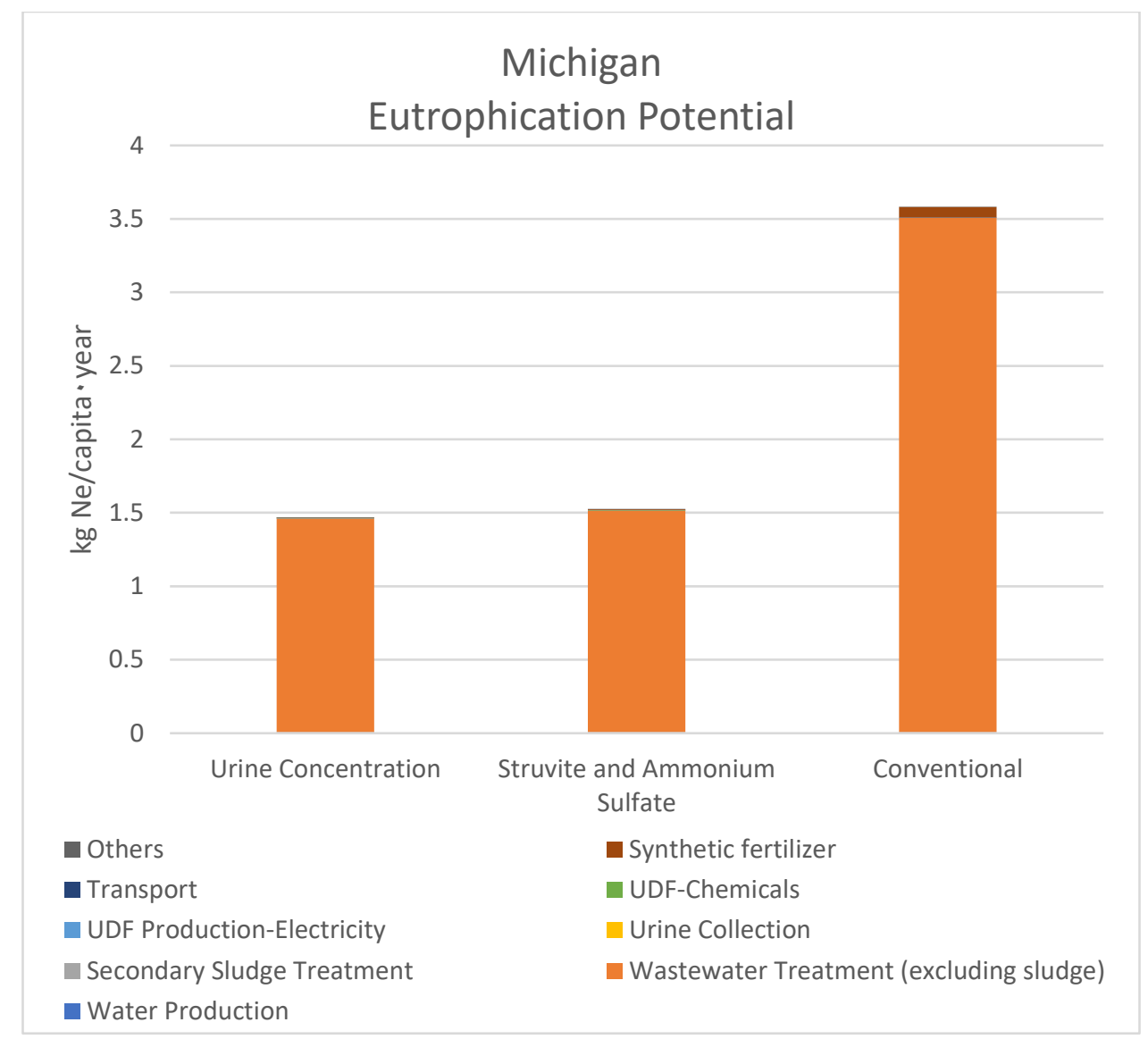

Figure 17. Eutrophication potential of the Michigan alternatives by Process. 


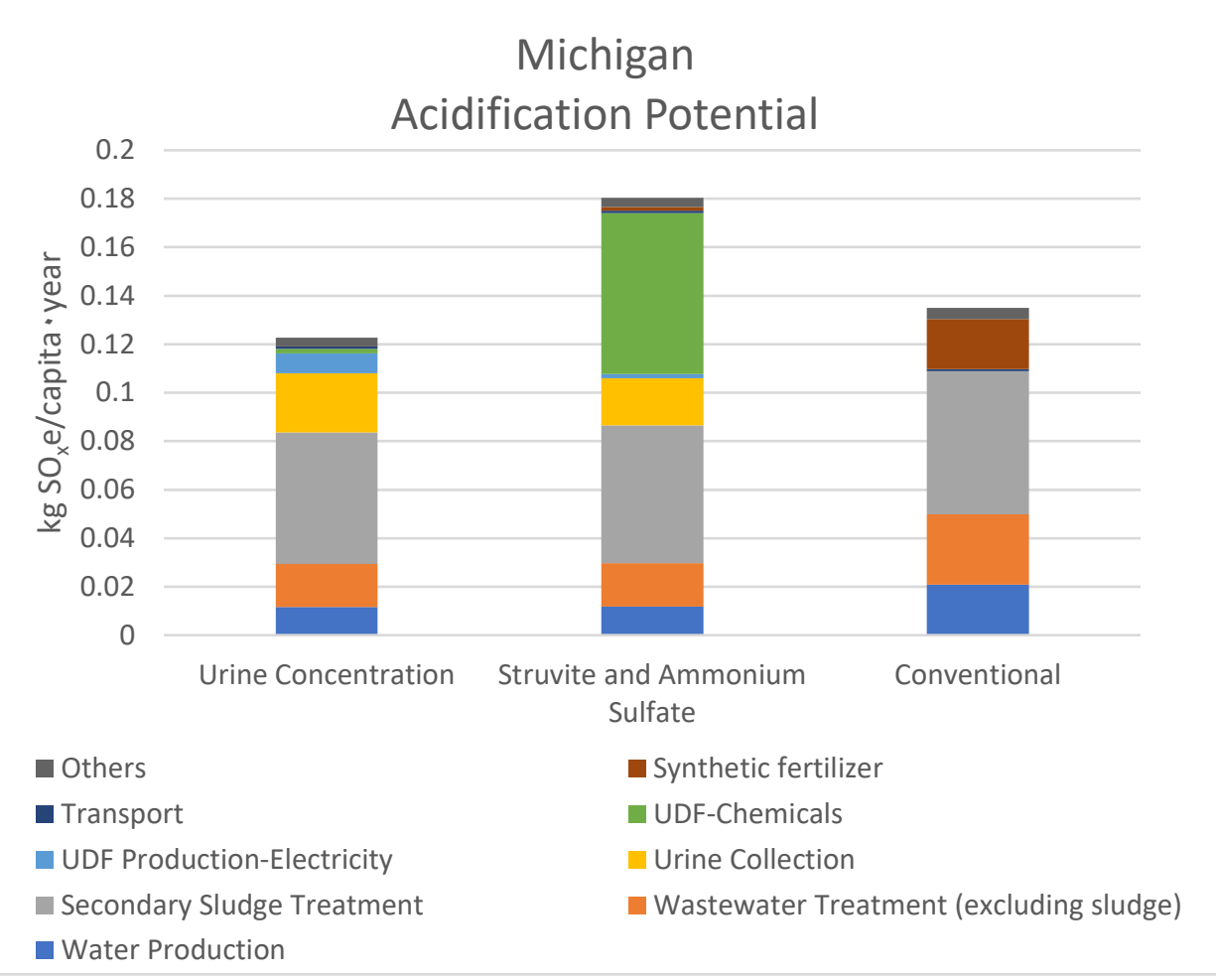

Figure 18. Acidification potential of the Virginia alternatives by Process.

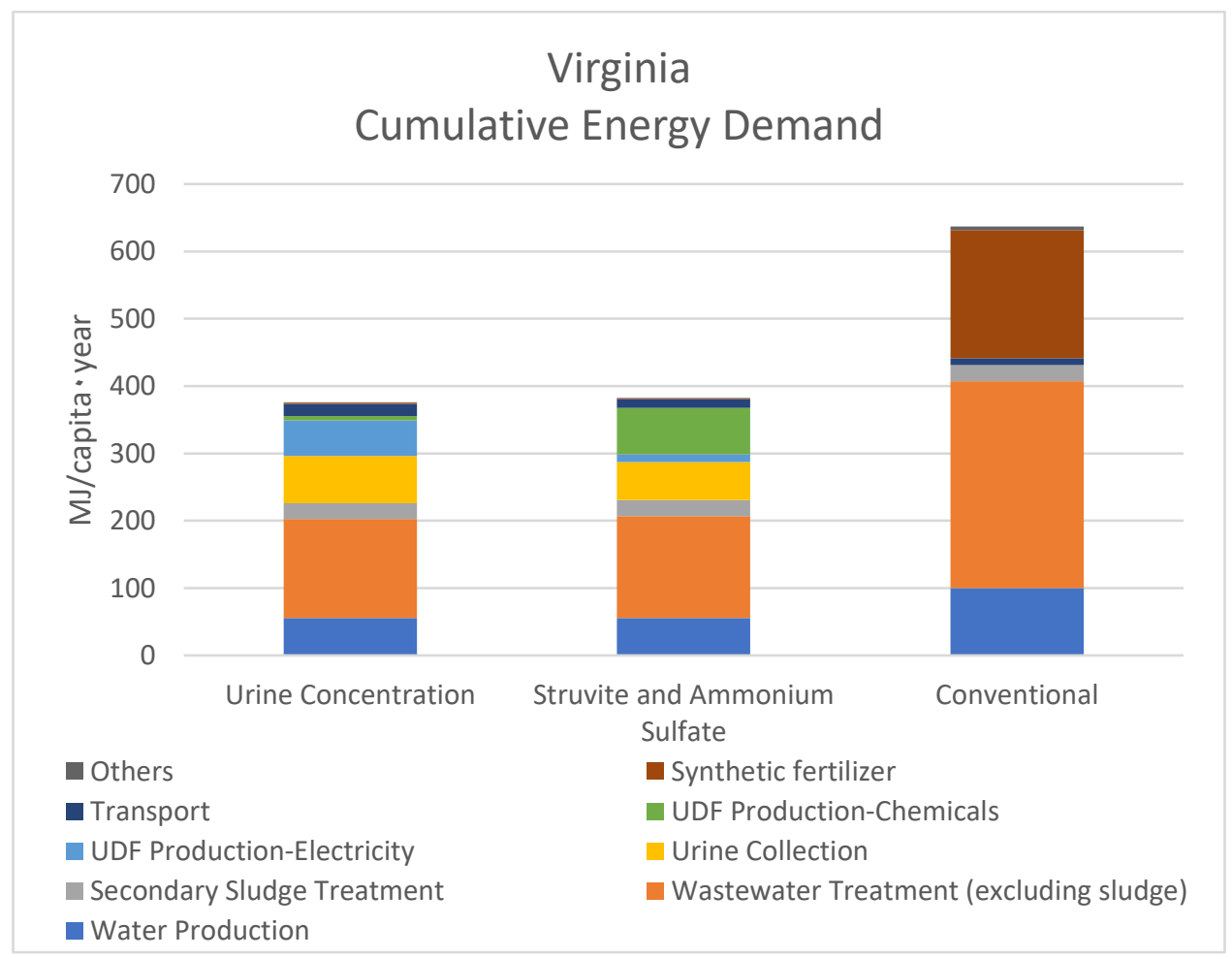

Figure 19. CED of the Virginia alternatives by Process. 


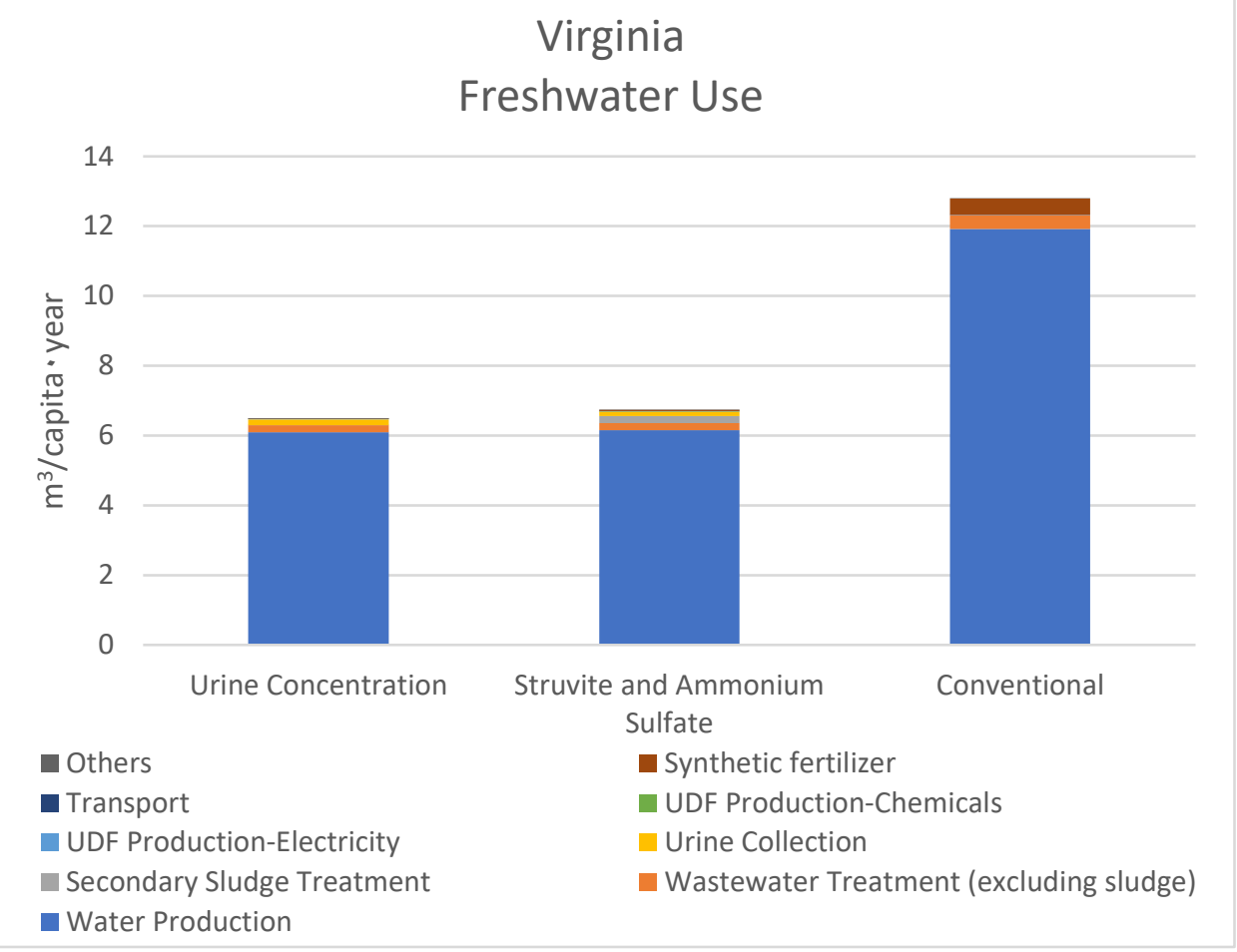

Figure 20. Freshwater use of the Virginia alternatives by Process.

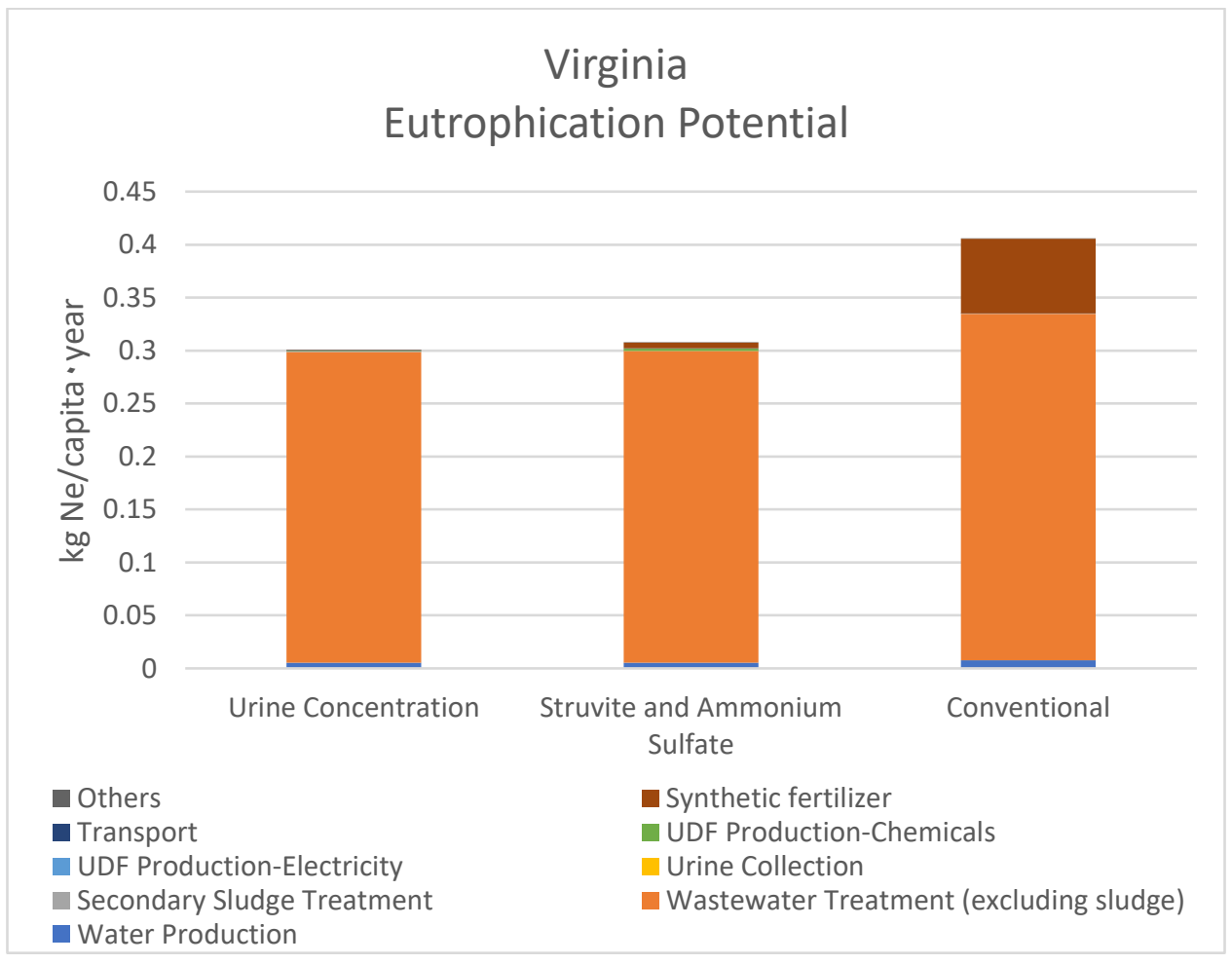

Figure 21. Eutrophication potential of the Virginia alternatives by Process. 


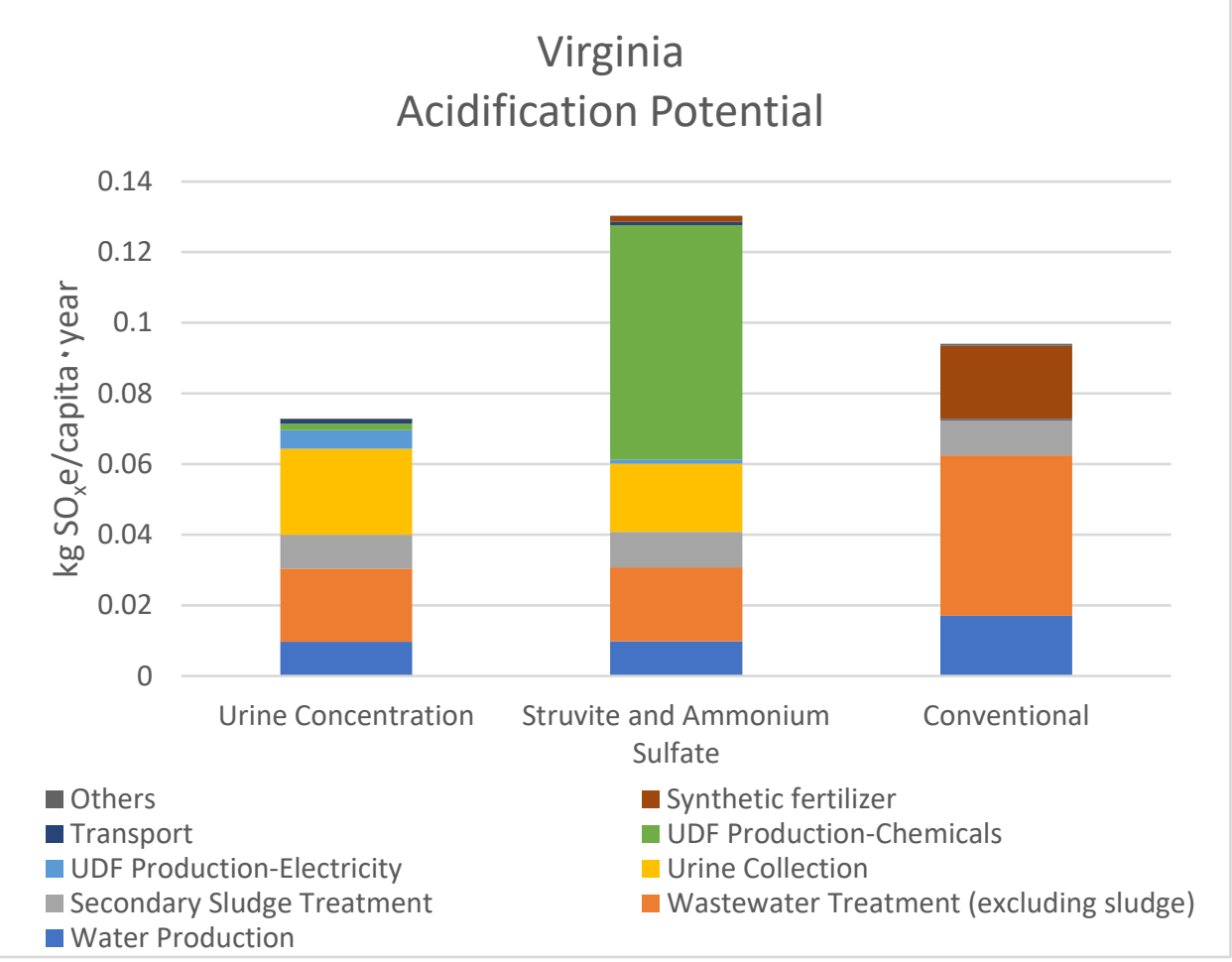

Figure 22. Acidification potential of the Virginia alternatives by Process.

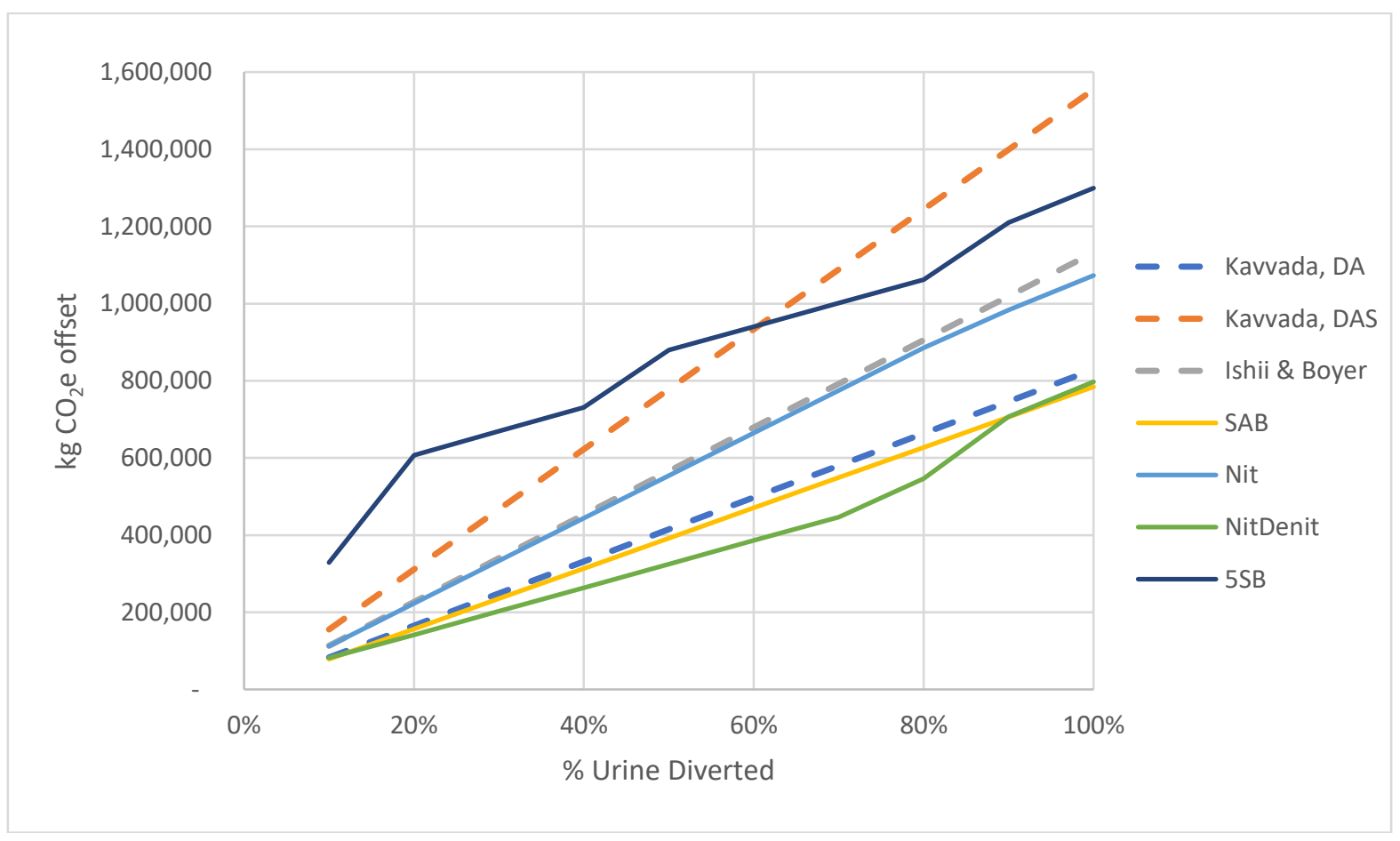

Figure 23. Comparison of WWTP Modeling Methods.

Comparison of GWP savings from wastewater treatment by percent diversion of urine from this study and two other LCAs. All demonstrate urine diversion for a population of 100,000 people and use the average US electricity grid. All measurements are taken at 10\% increments. DA is short for "Direct + aeration emissions," DAS is short for "Direct + aeration + substrate 
emissions," SAB is short for "Single Aeration Basin," Nit is short for "Nitrification," NitDenit is short for "Nitrification and Denitrification," and 5SB is short for "5-Stage Bardenpho."

The simpler methods used in other studies to estimate how much urine diversion reduces the greenhouse gas emissions associated with wastewater treatment produce relatively similar results. ${ }^{48,49}$ Using a denitrification emission factor without substrate emissions can be a close approximation for less stringent treatment plants, even though some do not actually use denitrification. ${ }^{49}$ Using a denitrification emission factor with substrate emissions leads to results relatively close to the stringent 5-Stage Bardenpho treatment plant modeled in this study. Offsetting by volume of wastewater treatment can produce relatively similar results, though it is worth noting that the wastewater treatment plant in Ishii and Boyer's study consumes more electricity per cubic meter of wastewater than most. ${ }^{48,59}$ This volumetric approach may underestimate actual savings when the electricity grid uses a large proportion of renewable energy sources, a urine diverting toilet's flush volume is not much lower than the alternative, or when the wastewater treatment plant does not consume an above average amount of electricity per volume wastewater.

Most treatment plants did not have constant improvements as the level of urine diversion increased. Whenever the need for a chemical input is eliminated, increases to urine diversion past that point lead to smaller environmental gains. At certain levels of urine diversion, the treatment configuration of the treatment plant could be simplified, leading to relatively large environmental benefits. Using simplified methods to estimate changes to wastewater treatment will not capture these complexities. They are useful as a reasonable approximation of environmental benefits. The methods in this study would be useful for a more accurate approximation, for a clearer idea 
of how operations will change (e.g. typically will not need external carbon sources), or comparing the merits and drawbacks of different levels of urine diversion. 


\section{APPENDIX G: RESULTS OF THE SENSITIVITY ANALYSIS}

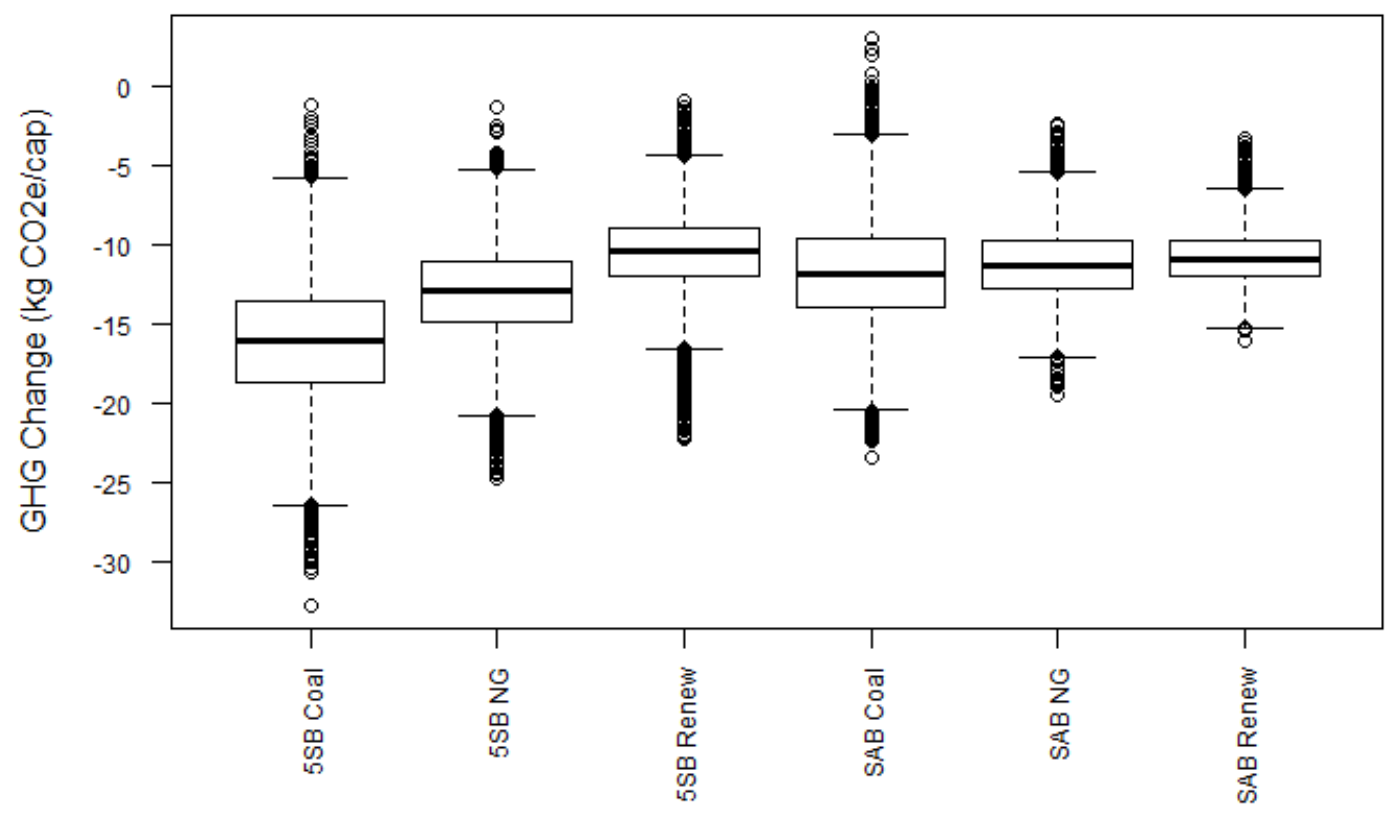

Figure 24. Differences in GHGs from Urine Concentration in sensitivity analysis. Each of the 10,000 simulations calculates the difference between the urine concentration and conventional alternative. The GHG Change is the difference in greenhouse gases.

5SB is short for 5-Stage Bardenpho, and SAB is short for Single Aeration Basin.

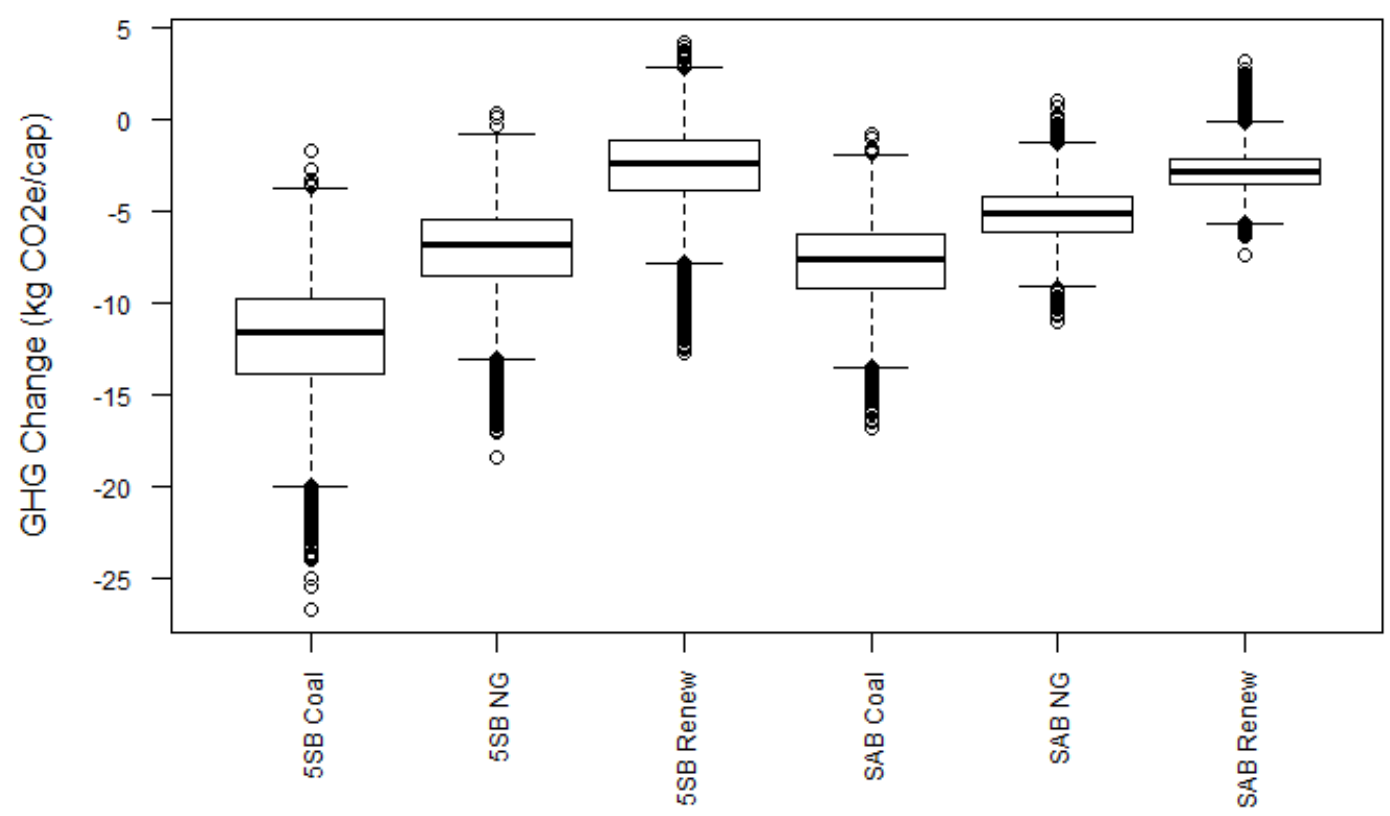

Figure 25. Differences in GHGs from Struvite and Ammonium Sulfate in sensitivity analysis. Box plot of change of greenhouse gas emissions of struvite and ammonium sulfate alternatives compared to conventional scenarios. 


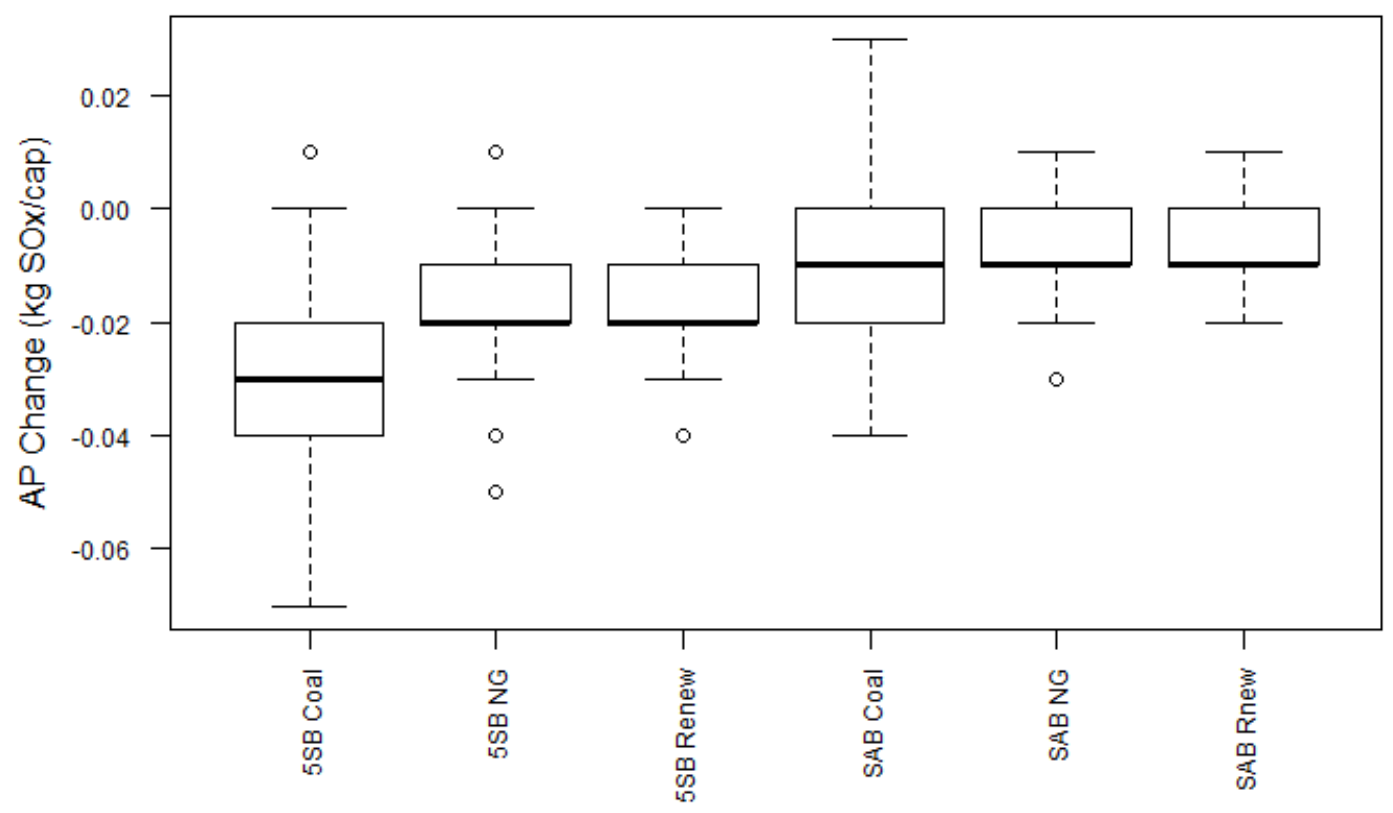

Figure 26. Differences in APs from Urine Concentration in sensitivity analysis.

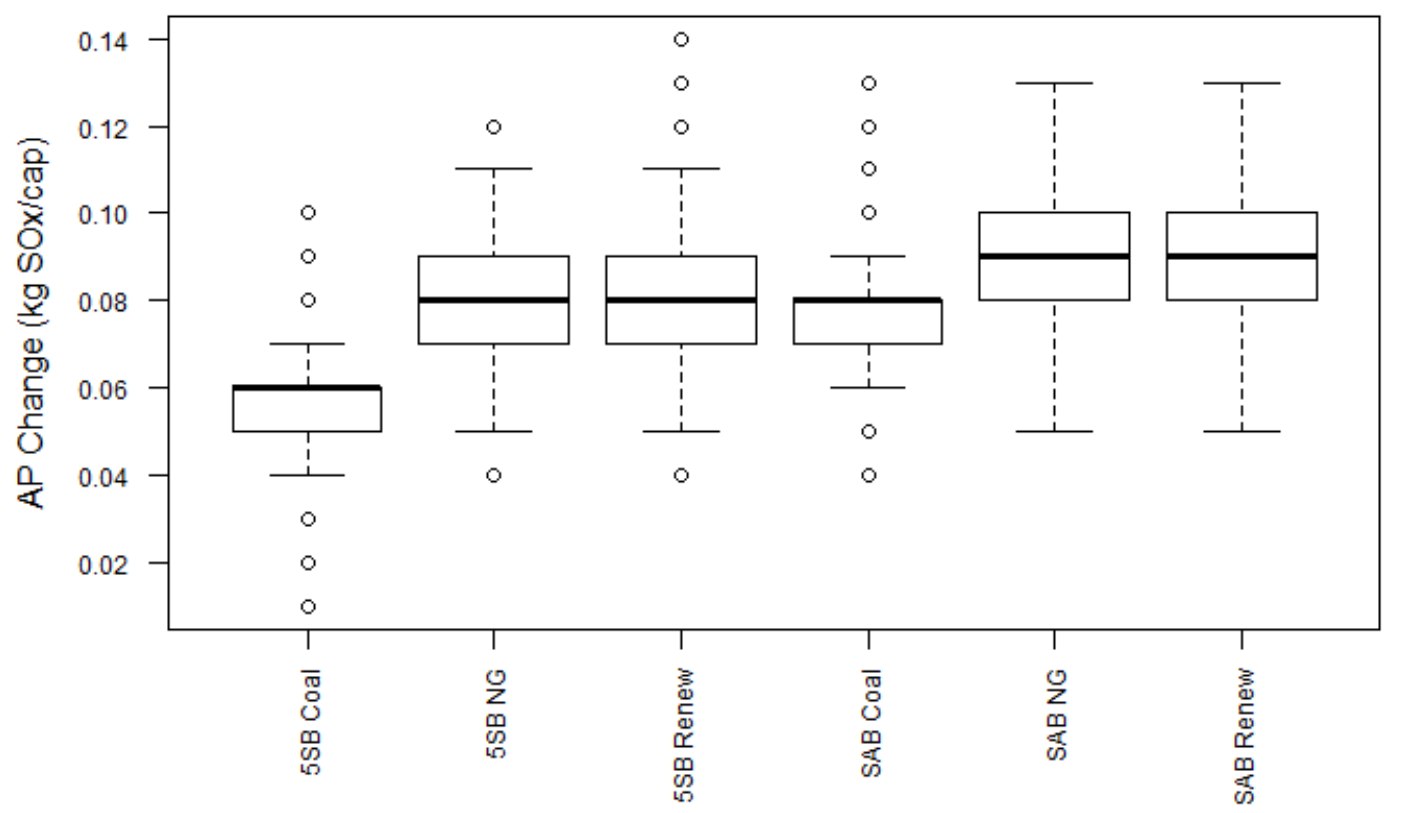

Figure 27. Differences in APs from Struvite and Ammonium Sulfate in sensitivity analysis. Positive values indicate increases in acidification potential. 


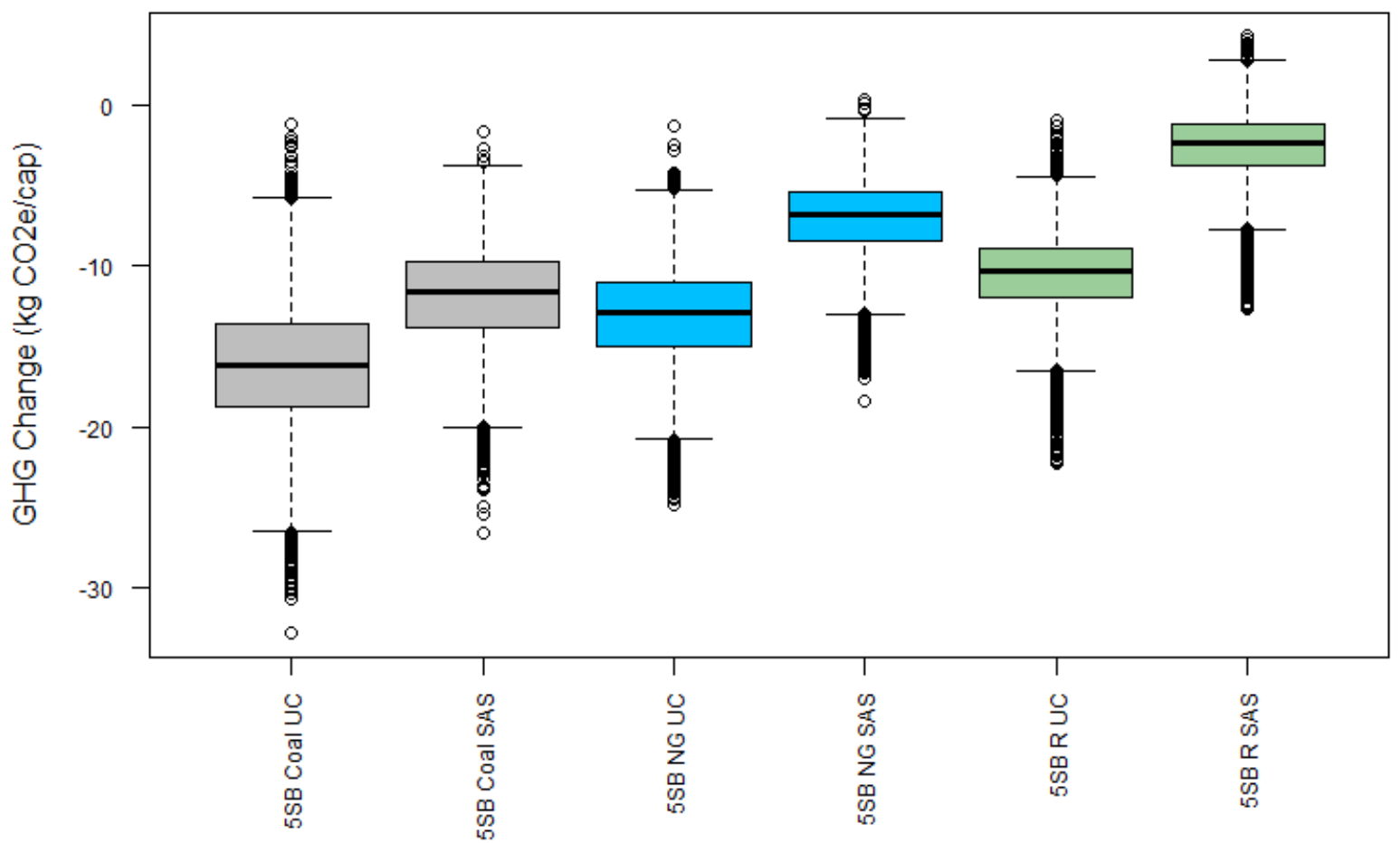

Figure 28. GWP Comparison of Urine Concentration and Struvite and Ammonium Sulfate in $5 S B$.

All data shown are from the 5-Stage Bardenpho plant modeled. UC is short for Urine Concentration, and SAS is short for Struvite and Ammonium Sulfate. Gray plots indicate coal is used, blue indicate natural gas, and green indicate renewable electricity.

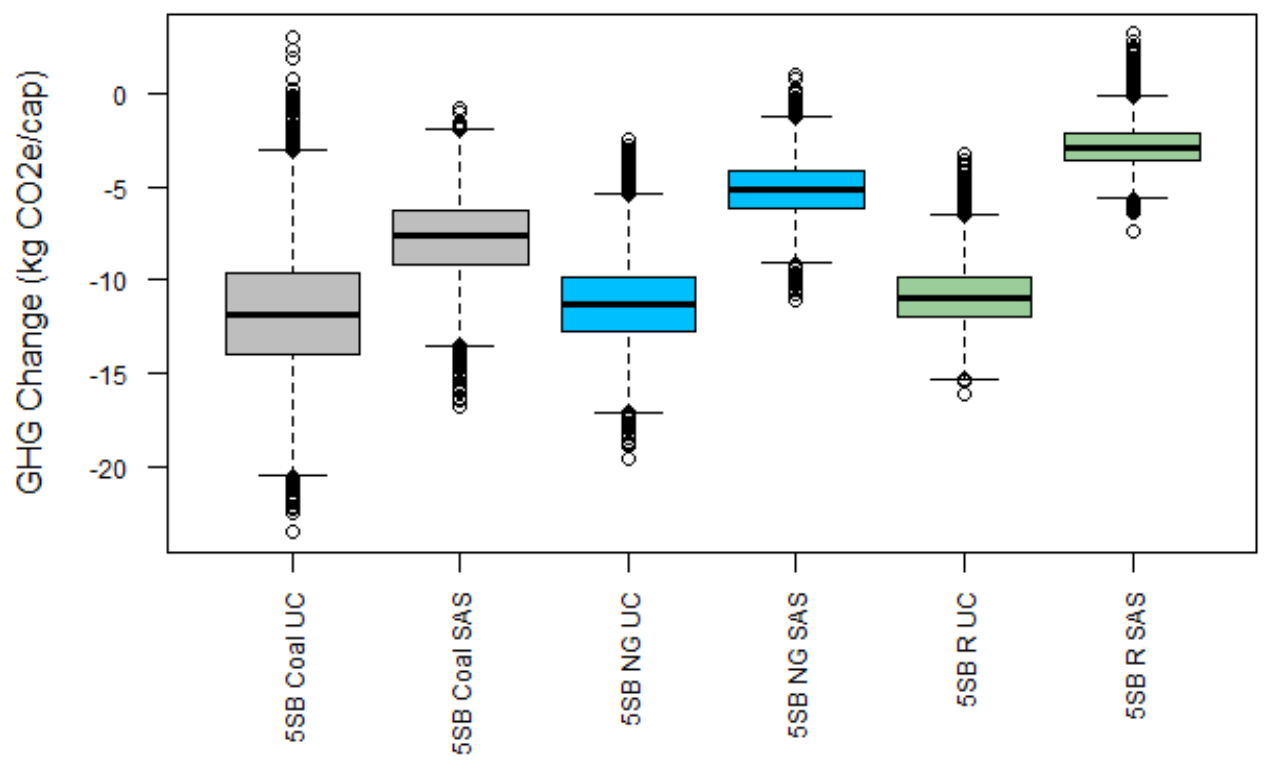

Figure 29. GWP Comparison of Urine Concentration and Struvite and Ammonium Sulfate in $S A B$. 
All data shown are from the single aeration basin plant modeled. UC is short for Urine Concentration, and SAS is short for Struvite and Ammonium Sulfate. Gray plots indicate coal is used, blue indicate natural gas, and green indicate renewable electricity.

Table 21. Urine Concentration Scenarios with lower GWP.

Percent of simulations where urine concentration had lower greenhouse gas emissions than the conventional alternative with different scopes. The first row is what was measured in the study, the second row is iffertilizer offsets were not considered, and the third row is if $\mathrm{N}_{2} \mathrm{O}$ emissions from effluent were not considered.

\begin{tabular}{|c|c|c|c|c|c|c|}
\hline & \multicolumn{7}{|c|}{ Urine Concentration } \\
\hline & $\begin{array}{c}\text { 5SB } \\
\text { Coal }\end{array}$ & $\begin{array}{c}\text { 5SB } \\
\text { NG }\end{array}$ & 5SB Renew & $\begin{array}{c}\text { SAB } \\
\text { Coal }\end{array}$ & $\begin{array}{c}\text { SAB } \\
\text { NG }\end{array}$ & SAB Renew \\
\hline Standard & $100.0 \%$ & $99.9 \%$ & $100.0 \%$ & $100.0 \%$ & $100.0 \%$ & $100.0 \%$ \\
\hline W/o fert offset & $97.5 \%$ & $94.5 \%$ & $77.2 \%$ & $82.6 \%$ & $88.7 \%$ & $92.7 \%$ \\
\hline W/o external $\mathbf{N}_{2} \mathbf{O}$ & $100.0 \%$ & $100.0 \%$ & $100.0 \%$ & $99.3 \%$ & $100.0 \%$ & $1.0 \%$ \\
\hline
\end{tabular}

Table 22. Struvite and Ammonium Sulfate Scenarios with lower GWP.

Percent of simulations where struvite and ammonium sulfate had lower greenhouse gas emissions than the conventional alternative with different scopes. The first row is what was measured in the study, the second row is if fertilizer offsets were not considered, and the third row is if $\mathrm{N}_{2} \mathrm{O}$ emissions from effluent were not considered.

\begin{tabular}{|c|c|c|c|c|c|c|}
\hline & \multicolumn{6}{|c|}{ Struvite and Ammonium Sulfate } \\
\hline & 5SB Coal & $\begin{array}{c}\text { 5SB } \\
\text { NG }\end{array}$ & 5SB Renew & $\begin{array}{c}\text { SAB } \\
\text { Coal }\end{array}$ & $\begin{array}{c}\text { SAB } \\
\text { NG }\end{array}$ & SAB Renew \\
\hline Standard & $100.0 \%$ & $100.0 \%$ & $91.7 \%$ & $100.0 \%$ & $99.9 \%$ & $98.7 \%$ \\
\hline W/o fert offset & $85.9 \%$ & $19.8 \%$ & $2.6 \%$ & $27.7 \%$ & $0.2 \%$ & $0.0 \%$ \\
\hline W/o external N2O & $100.0 \%$ & $100.0 \%$ & $91.4 \%$ & $99.4 \%$ & $93.8 \%$ & $0.4 \%$ \\
\hline
\end{tabular}




\section{REFERENCES}

1. Stewart, W. M., Dibb, D. W., Johnston, A. E. \& Smyth, T. J. The contribution of commercial fertilizer nutrients to food production. Agron. J. 97, 1-6 (2005).

2. Scholz, R. W. \& Wellmer, F.-W. Although there is no Physical Short-Term Scarcity of Phosphorus, its Resource Efficiency Should be Improved. J. Ind. Ecol. (2018). doi:10.1111/jiec. 12750

3. Cordell, D. \& White, S. Peak phosphorus: Clarifying the key issues of a vigorous debate about long-term phosphorus security. Sustainability 3, 2027-2049 (2011).

4. Cordell, D., Drangert, J.-O. \& White, S. The story of phosphorus: Global food security and food for thought. Glob. Environ. Chang. 19, 292-305 (2009).

5. Chen, M. \& Graedel, T. E. A half-century of global phosphorus flows, stocks, production, consumption, recycling, and environmental impacts. Glob. Environ. Chang. 36, 139-152 (2016).

6. Dawson, C. J. \& Hilton, J. Fertiliser availability in a resource-limited world: Production and recycling of nitrogen and phosphorus. Food Policy 36, (2011).

7. Wood, Sam; Cowie, A. A Review of Greenhouse Gas Emissions for Fertiliser Production. Coop. Res. Cent. Greenh. Account. 20 (2004).

8. Jacobs, B., Cordell, D., Chin, J. \& Rowe, H. Towards phosphorus sustainability in North America: A model for transformational change. Environ. Sci. Policy 77, 151-159 (2017).

9. Elliot, T. Energy-Saving Opportunities for Wastewater Facilities: A Review. Energy Cent. Wisconsin 221-1, (2003). 
10. U.S. EPA. State and Local Climate and Energy Program: Water/Wastewater. (2012). Available at: https://www.epa.gov/statelocalenergy.

11. Guest, J. S. et al. A new planning and design paradigm to achieve sustainable resource recovery from wastewater. Environ. Sci. Technol. 43, 6126-6130 (2009).

12. Roy, E. D. Phosphorus recovery and recycling with ecological engineering: A review. Ecol. Eng. 98, 213-227 (2017).

13. Lam, L., Kurisu, K. \& Hanaki, K. Comparative environmental impacts of sourceseparation systems for domestic wastewater management in rural China. J. Clean. Prod. 104, 185-198 (2015).

14. Lundin, M., Bengtsson, M. \& Molander, S. Life cycle assessment of wastewater systems: Influence of system boundaries and scale on calculated environmental loads. Environ. Sci. Technol. 34, 180-186 (2000).

15. Maurer, M., Pronk, W. \& Larsen, T. A. Treatment processes for source-separated urine. Water Res. 40, 3151-3166 (2006).

16. Slagstad, H. \& Bratteb $\varnothing$, H. Life cycle assessment of the water and wastewater system in Trondheim, Norway - A case study: Case Study. Urban Water J. 11, 323-334 (2014).

17. Pasqualino, J. C., Meneses, M., Abella, M. \& Castells, F. LCA as a decision support tool for the environmental improvement of the operation of a municipal wastewater treatment plant. Environ. Sci. Technol. 43, 3300-3307 (2009).

18. Wilsenach, J. \& Van Loosdrecht, M. Impact of separate urine collection on wastewater treatment systems. Water Science and Technology 48, (2003). 
19. Simha, P. \& Ganesapillai, M. Ecological Sanitation and nutrient recovery from human urine: How far have we come? A review. Sustain. Environ. Res. 27, 107-116 (2017).

20. Johnston, A. E. \& Richards, I. R. Effectiveness of different precipitated phosphates as phosphorus sources for plants. Soil Use Manag. 19, 45-49 (2003).

21. Ricardo, G.-P., López-de-Sá, E. G. \& Plaza, C. Lettuce response to phosphorus fertilization with struvite recovered from municipal wastewater. HortScience 44, 426-430 (2009).

22. Skowronska, M. \& Filipek, T. Life cycle assessment of fertilizers: a review. Int. Agrophysics 28, 101-110 (2014).

23. Sloan, J. J., Dowdy, R. H., Dolan, M. S. \& Linden, D. R. Long-term effects of biosolids applications on heavy metal bioavailability in agricultural soils. J. Environ. Qual. 26, 966-974 (1997).

24. Jönsson, H., Stenström, T.-A., Svensson, J. \& Sundin, A. Source separated urine-nutrient and heavy metal content, water saving and faecal contamination. Water Science and Technology 35, (1997).

25. Wigginton, K. R. et al. Nutrient Recovery Through Urine Separation. (2017).

26. Diaz-Elsayed, N., Rezaei, N., Guo, T., Mohebbi, S. \& Zhang, Q. Wastewater-based resource recovery technologies across scale: A review. Resour. Conserv. Recycl. 145, 94112 (2019).

27. Udert, K. M., Larsen, T. A., Biebow, M. \& Gujer, W. Urea hydrolysis and precipitation dynamics in a urine-collecting system. Water Res. 37, 2571-2582 (2003). 
28. Ray, H., Saetta, D. \& Boyer, T. H. Characterization of urea hydrolysis in fresh human urine and inhibition by chemical addition. Environ. Sci. Water Res. Technol. 4, 87-98 (2018).

29. Saetta, D. \& Boyer, T. H. Mimicking and Inhibiting Urea Hydrolysis in Nonwater Urinals. Environ. Sci. Technol. 51, 13850-13858 (2017).

30. Thörneby, L., Persson, K. \& Trägårdh, G. Treatment of liquid effluents from dairy cattle and pigs using reverse osmosis. J. Agric. Eng. Res. 73, 159-170 (1999).

31. Tian, X. et al. Reverse osmosis brine for phosphorus recovery from source separated urine. Chemosphere 165, 202-210 (2016).

32. Lorain, O., Thiebaud, P., Badorc, E. \& Aurelle, Y. Potential of freezing in wastewater treatment: Soluble pollutant applications. Water Res. 35, 541-547 (2001).

33. Gulyas, H. et al. Freeze concentration for enrichment of nutrients in yellow water from no-mix toilets. Water Science and Technology 50, (2004).

34. Lind, B.-B., Ban, Z. \& Bydén, S. Volume reduction and concentration of nutrients in human urine. Ecol. Eng. 16, 561-566 (2001).

35. Bridger, G. L., Salutsky, M. L. \& Starostka, R. W. Micronutrient Sources, Metal Ammonium Phosphates as Fertilizers. J. Agric. Food Chem. 10, 181-188 (1962).

36. Ganrot, Z., Dave, G. \& Nilsson, E. Recovery of N and P from human urine by freezing, struvite precipitation and adsorption to zeolite and active carbon. Bioresour. Technol. 98, 3112-3121 (2007).

37. Doyle, J. D. \& Parsons, S. A. Struvite formation, control and recovery. Water Res. 36, 
3925-3940 (2002).

38. Schuiling, R. D. \& Andrade, A. Recovery of struvite from calf manure. Environ. Technol. (United Kingdom) 20, 765-768 (1999).

39. Tarpeh, W. A., Udert, K. M. \& Nelson, K. L. Comparing ion exchange adsorbents for nitrogen recovery from source-separated urine. Environ. Sci. Technol. 51, 2373-2381 (2017).

40. Ganesapillai, M., Simha, P. \& Zabaniotou, A. Closed-loop fertility cycle: Realizing sustainability in sanitation and agricultural production through the design and implementation of nutrient recovery systems for human urine. Sustain. Prod. Consum. 4, 36-46 (2015).

41. Udert, K. M. \& Wächter, M. Complete nutrient recovery from source-separated urine by nitrification and distillation. Water Res. 46, 453-464 (2012).

42. International Standards Organization (ISO). International Standard 14040: Life Cycle Assessment-Principles and Framework. (2006).

43. International Standards Organization (ISO). ISO 14044: Life Cycle Assessment Principles and Framework. (2006).

44. Arpke, A. \& Hutzler, N. Domestic water use in the United States: A life-cycle approach. J. Ind. Ecol. 10, 169-184 (2006).

45. Rahman, S. M., Eckelman, M. J., Onnis-Hayden, A. \& Gu, A. Z. Life-Cycle Assessment of Advanced Nutrient Removal Technologies for Wastewater Treatment. Environ. Sci. Technol. 50, 3020-3030 (2016). 
46. Corominas, L. et al. Life cycle assessment applied to wastewater treatment: State of the art. Water Res. 47, 5480-5492 (2013).

47. Risch, E., Gutierrez, O., Roux, P., Boutin, C. \& Corominas, L. Life cycle assessment of urban wastewater systems: Quantifying the relative contribution of sewer systems. Water Res. 77, 35-48 (2015).

48. Ishii, S. K. L. \& Boyer, T. H. Life cycle comparison of centralized wastewater treatment and urine source separation with struvite precipitation: Focus on urine nutrient management. Water Res. 79, 88-103 (2015).

49. Kavvada, O., Tarpeh, W. A., Horvath, A. \& Nelson, K. L. Life-cycle cost and environmental assessment of decentralized nitrogen recovery using ion exchange from source-separated urine through spatial modeling. Environ. Sci. Technol. 51, 12061-12071 (2017).

50. Remy, C. \& Jekel, M. Energy analysis of conventional and source-separation systems for urban wastewater management using Life Cycle Assessment. Water Sci. Technol. 65, 2229 (2012).

51. Xue, X., Hawkins, T. R., Schoen, M. E., Garland, J. \& Ashbolt, N. J. Comparing the life cycle energy consumption, globalwarming and eutrophication potentials of several water and waste service options. Water (Switzerland) 8, (2016).

52. Jimenez, J., Bott, C., Love, N. \& Bratby, J. Source Separation of Urine as an Alternative Solution to Nutrient Management in Biological Nutrient Removal Treatment Plants. Water Environ. Res. 87, 2120-2129 (2015). 
53. Ekama, G. A., Wilsenach, J. A. \& Chen, G. H. Saline sewage treatment and source separation of urine for more sustainable urban water management. Water Sci. Technol. 64, 1307-1316 (2011).

54. Wilsenach, J. A., Schuurbiers, C. A. H. \& van Loosdrecht, M. C. M. Phosphate and potassium recovery from source separated urine through struvite precipitation. Water Res. 41, 458-466 (2007).

55. Maupin, M. et al. Estimated Use of Water in the United States in 2010. U.S. Geol. Surv. Circ. 56 (2014).

56. Bonton, A., Bouchard, C., Barbeau, B. \& Jedrzejak, S. Comparative life cycle assessment of water treatment plants. Desalination 284, 42-54 (2012).

57. D\&R International, L. 2011 Buildings Energy Data Book. (U.S. Department of Energy, 2012).

58. Elliot, T., Zeier, B., Xagoraraki, I. \& Harrington, G. Energy Use at Wisconsin's Drinking Water Utilities. (2002).

59. EPRI. Water \& Sustainability (Volume 4): U.S. Electricity Consumption for Water Supply \& Treatment - The Next Half Century. (2002).

60. Godskesen, B., Hauschild, M., Rygaard, M., Zambrano, K. \& Albrechtsen, H.-J. Life cycle assessment of central softening of very hard drinking water. J. Environ. Manage. 105, 83-89 (2012).

61. Jeong, H., Minne, E. \& Crittenden, J. C. Life cycle assessment of the City of Atlanta, Georgia's centralized water system. Int. J. Life Cycle Assess. 20, 880-891 (2015). 
62. Kjellsson, J. B., Greene, D., Bhattarai, R. \& Webber, M. E. Energy benchmarking of water and wastewater treatment, distribution and collection: A case study of Austin water utility. in ASME International Mechanical Engineering Congress and Exposition, Proceedings (IMECE) 6 B, (2013).

63. Mo, W., Nasiri, F., Eckelman, M. J., Zhang, Q. \& Zimmerman, J. B. Measuring the embodied energy in drinking water supply systems: A case study in the Great Lakes region. Environ. Sci. Technol. 44, 9516-9521 (2010).

64. Renzoni, R. \& Germain, A. Life Cycle Assessment of Water from the Pumping Station to the Wastewater Treatment Plant. Int J Life Cycle Assess. 12, 118 (2007).

65. Stokes, J. R. \& Horvath, A. Energy and air emission effects of water supply. Environ. Sci. Technol. 43, 2680-2687 (2009).

66. Tripathi, M. Life-Cycle Energy and Emissions for Municipal Water and Wastewater Services: Case-Studies of Treatment Plants in US. (University of Michigan, 2007).

67. Plappally, A. K. \& Lienhard V, J. H. Energy requirements for water production, treatment, end use, reclamation, and disposal. Renew. Sustain. Energy Rev. 16, 4818-4848 (2012).

68. CABOT. Norit PK 3-5. (2018).

69. Bayer, P., Heuer, E., Karl, U. \& Finkel, M. Economical and ecological comparison of granular activated carbon (GAC) adsorber refill strategies. Water Res. 39, 1719-1728 (2005).

70. He, K. A calculation of the environmental footprint of a granular activated carbon regeneration facility. Clim. Energy Sect. Environ. Sci. Sr. Thesis Symp. UC Berkeley 
Environ. Sci. 22, 28 (2012).

71. Hutchins, R. A. Thermal Regeneration Costs. Chem. Eng. Prog. 71, 80-86 (1975).

72. Meier, M. Eco-efficiency evaluation of waste gas purification systems in the chemical industry. (ETH Zurich, 1997).

73. Hydranautics. Foulants and Cleaning Procedures for composite polyamide RO Membrane Elements (ESP, ESNA, CPA, LFC, NANO and SWC). Technical Service Bulletin 16 (2014). Available at: http://www.membranes.com/docs/tsb/TSB107.pdf. (Accessed: 3rd July 2018)

74. Hilton, S. et al. Life Cycle Assessment of Urine Diversion Wastewater Treatment: Results and Software Tool. (2018).

75. Antonini, S., Arias, M. A., Eichert, T. \& Clemens, J. Greenhouse evaluation and environmental impact assessment of different urine-derived struvite fertilizers as phosphorus sources for plants. Chemosphere 89, 1202-1210 (2012).

76. Achat, D. L. et al. Plant-availability of phosphorus recycled from pig manures and dairy effluents as assessed by isotopic labeling techniques. Geoderma 232, 24-33 (2014).

77. Germer, J., Addai, S. \& Sauerborn, J. Response of grain sorghum to fertilisation with human urine. F. Crop. Res. 122, 234-241 (2011).

78. Zhang, Z. \& Wilson, F. Life-cycle assessment of a sewage-treatment plant in south-east asia. Water Environ. J. 14, 51-56 (2000).

79. Piratla, K. R., Ariaratnam, S. T. \& Cohen, A. Estimation of CO $<$ inf $>2</$ inf $>$ emissions from the life cycle of a potable water pipeline project. J. Manag. Eng. 28, 22-30 (2012). 
80. Lundie, S., Peters, G. M. \& Beavis, P. C. Life cycle assessment for sustainable metropolitan water systems planning. Environ. Sci. Technol. 38, 3465-3473 (2004).

81. EMMERSON, R. H. C., MORSE, G. K., LESTER, J. N. \& EDGE, D. R. The Life-Cycle Analysis of Small-Scale Sewage-Treatment Processes. Water and Environment Journal, 9(3), 317-325. https://doi.org/10.1111/j.1747. Water Environ. J. 9, 317-325 (1995).

82. National Renewable Energy Laboratory. U.S. Life Cycle Inventory Database. (2012).

83. ecoinvent. ecoinvent 3.4. (2017). Available at: https://www.ecoinvent.org/.

84. Koehler, A. Water use in LCA: Managing the planet's freshwater resources. Int. J. Life Cycle Assess. 13, 451-455 (2008).

85. WRF. Residential End Uses of Water, Version 2. (2016).

86. FitzGerald, M. P., Stablein, U. \& Brubaker, L. Urinary habits among asymptomatic women. Am. J. Obstet. Gynecol. 187, 1384-1388 (2002).

87. Friedler, E., Butler, D. \& Brown, D. M. Domestic WC usage patterns. Build. Environ. 31, 385-392 (1996).

88. Vickers, A. Handbook of Water Use and Conservation. (Waterplow Press, 2001).

89. Burgio, K. L., Engel, B. T. \& Locher, J. L. Normative patterns of diurnal urination across 6 age decades. J. Urol. 145, 728-731 (1991).

90. Sanjoaquin, M. A., Appleby, P. N., Spencer, E. A. \& Key, T. J. Nutrition and lifestyle in relation to bowel movement frequency: A cross-sectional study of 20630 men and women in EPIC-Oxford. Public Health Nutr. 7, 77-83 (2004). 
91. Abegglen, C. K. Membrane bioreactor technology for decentralized wastewater treatment and reuse. (ETH Zurich, 2008).

92. Antonini, S., Paris, S., Eichert, T. \& Clemens, J. Nitrogen and Phosphorus Recovery from Human Urine by Struvite Precipitation and Air Stripping in Vietnam. Clean - Soil, Air, Water 39, 1099-1104 (2011).

93. Dastur, M. Investigation into the factors affecting controlled struvite crystallization at the bench-scale. (University of British Columbia, 2001).

94. Ronteltap, M., Maurer, M., Hausherr, R. \& Gujer, W. Struvite precipitation from urine Influencing factors on particle size. Water Res. 44, 2038-2046 (2010).

95. Grundestam, J. \& Hellström, D. Wastewater treatment with anaerobic membrane bioreactor and reverse osmosis. Water Science and Technology 56, (2007).

96. Ledda, C., Schievano, A., Salati, S. \& Adani, F. Nitrogen and water recovery from animal slurries by a new integrated ultrafiltration, reverse osmosis and cold stripping process: A case study. Water Res. 47, 6157-6166 (2013).

97. Middleton, M. SimVoi Monte Carlo Simulation Add-In. (2016).

98. Ganrot, Z., Dave, G. \& Nilsson, E. Recovery of N and P from human urine by freezing, struvite precipitation and adsorption to zeolite and active carbon. Bioresour. Technol. 98, 3112-3121 (2007).

99. USDA. Fertilizer Use and Price. (2016).

100. Trimmer, J. T. \& Guest, J. S. Recirculation of human-derived nutrients from cities to agriculture across six continents. Nat. Sustain. 1, 427-435 (2018). 
101. Metson, G. S., Bennett, E. M. \& Elser, J. J. The role of diet in phosphorus demand. Environ. Res. Lett. 7, (2012).

102. Ibarrola-Rivas, M. J. \& Nonhebel, S. Variations in the use of resources for food: Land, nitrogen fertilizer and food nexus. Sustain. 8, (2016).

103. Pierer, M., Winiwarter, W., Leach, A. M. \& Galloway, J. N. The nitrogen footprint of food products and general consumption patterns in Austria. Food Policy 49, 128-136 (2014).

104. Leach, A. M. et al. A nitrogen footprint model to help consumers understand their role in nitrogen losses to the environment. Environ. Dev. 1, 40-66 (2012).

105. Nagy, J., Mikola, A., Pradhan, S. K. \& Zseni, A. The utilization of struvite produced from human urine in agriculture as a natural fertilizer: A review. Period. Polytech. Chem. Eng. 63, 478-484 (2019).

106. McConville, J. R., Kvarnström, E., Jönsson, H., Kärrman, E. \& Johansson, M. Source separation: Challenges \&amp; opportunities for transition in the swedish wastewater sector. Resour. Conserv. Recycl. 120, 144-156 (2017).

107. Barquet, K., Järnberg, L., Rosemarin, A. \& Macura, B. Identifying barriers and opportunities for a circular phosphorus economy in the Baltic Sea region. Water Res. 171, (2020).

108. Segrè Cohen, A., Love, N. G., Nace, K. K. \& Árvai, J. Consumers’ Acceptance of Agricultural Fertilizers Derived from Diverted and Recycled Human Urine. Environ. Sci. Technol. 54, 5297-5305 (2020). 
109. Lienert, J. \& Larsen, T. A. Considering user attitude in early development of environmentally friendly technology: A case study of NoMix toilets. Environ. Sci. Technol. 40, 4838-4844 (2006).

110. Ampe, K., Paredis, E., Asveld, L., Osseweijer, P. \& Block, T. A transition in the Dutch wastewater system? The struggle between discourses and with lock-ins. J. Environ. Policy Plan. 22, 155-169 (2020).

111. EPA. Inventory of U.S. Greenhouse Gas Emissions and Sinks: 1990-2016. (2018).

112. IPCC. IPCC Guidelines for National Greenhouse Gas Inventories. (2006).

113. Law, Y., Jacobsen, G. E., Smith, A. M., Yuan, Z. \& Lant, P. Fossil organic carbon in wastewater and its fate in treatment plants. Water Res. 47, 5270-5281 (2013).

114. Metcalf \& Eddy, Tchobanoglous, G., Stensel, H. D., Tsuchihashi, R. \& Burton, F. Wastewater Engineering: Treatment and Resource Recovery. (McGraw-Hill Education, 2013).

115. Fittschen, I. \& Hahn, H. H. Characterization of the municipal wastewaterpart human urine and a preliminary comparison with liquid cattle excretion. Water Sci. Technol. 38, 9-16 (1998).

116. Henze, M. Waste design for households with respect to water, organics and nutrients. Water Science and Technology 35, (1997).

117. Larsen, T. A. \& Gujer, W. Separate management of anthropogenic nutrient solutions (human urine). Water Science and Technology 34, (1996).

118. Larsen, T. A., Udert, K. M. \& Lienert, J. Source Separation and Decentralization for 
Wastewater Management. (The International Water Association, 2013).

119. Wilsenach, J. A. \& van Loosdrecht, M. C. M. Integration of processes to treat wastewater and source-separated urine. J. Environ. Eng. 132, 331-341 (2006).

120. Larsen, T. A. CO2-neutral wastewater treatment plants or robust, climate-friendly wastewater management? A systems perspective. Water Res. 87, 513-521 (2015).

121. Henze, M., Gujer, W., Mino, T. \& Van Loosdrecht, M. Activated Sludge Models ASM1, ASM2, ASM2D, ASM3. (IWA, 2007).

122. Leslie Grady, C. P. L., Daigger, G. T., Love, N. G. \& Filipe, C. Biological wastewater treatment Third edition. IWA Publ. (2011).

123. Bare, J. TRACI 2.0: The tool for the reduction and assessment of chemical and other environmental impacts 2.0. Clean Technol. Environ. Policy 13, 687-696 (2011).

124. Doorn, M. et al. Wastewater Treatment and Discharge. in 2006 IPCC Guidelines for National Greenhouse Gas Inventories 6.1-6.28 (2006).

125. Hiatt, W. C. \& Grady Jr., C. P. L. An updated process model for carbon oxidation, nitrification, and denitrification. Water Environ. Res. 80, 2145-2156 (2008).

126. Rodriguez-Garcia, G., Hospido, A., Bagley, D. M., Moreira, M. T. \& Feijoo, G. A methodology to estimate greenhouse gases emissions in Life Cycle Inventories of wastewater treatment plants. Environ. Impact Assess. Rev. 37, 37-46 (2012).

127. Hart, V. Alkalinity Addition Utilizing Carbon Dioxide \& Lime: Inexpensive Solution to a Historically Expensive Problem. Florida Water Resour. J. 17-19 (2008).

128. Latini, J. M., Mueller, E., Lux, M. M., Fitzgerald, M. P. \& Kreder, K. J. Voiding 
frequency in a sample of asymptomatic American men. J. Urol. 172, 980-984 (2004).

129. Meinzinger, F. Resource Efficiency of Urban Sanitation Systems: A Comparative Assessment Using Material and Energy Flow Analysis. (Technische Universität Hamburg, 2010).

130. City of Ann Arbor, M. City of Ann Arbor 2018 Water Quality Report. (2018).

131. Schaper, D. As Infrastructure Crumbles, Trillions Of Gallons Of Water Lost. NPR (2014). Available at: https://www.npr.org/2014/10/29/359875321/as-infrastructure-crumblestrillions-of-gallons-of-water-lost. (Accessed: 9th January 2018)

132. Plappally, A. K. \& Lienhard V, J. H. Energy requirements for water production, treatment, end use, reclamation, and disposal. Renew. Sustain. Energy Rev. 16, 4818-4848 (2012).

133. Amores, M. J., Meneses, M., Pasqualino, J., Antón, A. \& Castells, F. Environmental assessment of urban water cycle on Mediterranean conditions by LCA approach. J. Clean. Prod. 43, 84-92 (2013).

134. Venkatesh, G. \& Bratteb $\varnothing$, H. Environmental analysis of chemicals and energy consumption in water treatment plants: Case study of Oslo, norway. Water Sci. Technol. Water Supply 12, 200-211 (2012).

135. Lemos, D., Dias, A. C., Gabarrell, X. \& Arroja, L. Environmental assessment of an urban water system. J. Clean. Prod. 54, 157-165 (2013).

136. Muñoz, I., Milà-i-Canals, L. \& Fernández-Alba, A. R. Life cycle assessment of water supply plans in Mediterranean Spain: the Ebro river transfer versus the AGUA Programme. J. Ind. Ecol. 14, 902-918 (2010). 
137. Sahely, H. R., Kennedy, C. A. \& Adams, B. J. Developing sustainability criteria for urban infrastructure systems. Can. J. Civ. Eng. 32, 72-85 (2005).

138. Racoviceanu, A. I., Karney, B. W., Kennedy, C. A. \& Colombo, A. F. Life-cycle energy use and greenhouse gas emissions inventory for water treatment systems. J. Infrastruct. Syst. 13, 261-270 (2007).

139. Buckley, C., Friedrich, E. \& von Blottnitz, H. Life-cycle assessments in the South African water sector: A review and future challenges. Water SA 37, 719-726 (2011).

140. Lorenzo-Toja, Y. et al. Beyond the conventional life cycle inventory in wastewater treatment plants. Sci. Total Environ. 553, 71-82 (2016).

141. Pasqualino, J. C., Meneses, M. \& Castells, F. Life Cycle Assessment of Urban Wastewater Reclamation and Reuse Alternatives. J. Ind. Ecol. 15, 49-63 (2011).

142. Qi, C. \& Chang, N.-B. Integrated carbon footprint and cost evaluation of a drinking water infrastructure system for screening expansion alternativesq. J. Clean. Prod. 60, 170-181 (2013).

143. Lienert, J., Bürki, T. \& Escher, B. I. Reducing micropollutants with source control: Substance flow analysis of 212 pharmaceuticals in faeces and urine. Water Science and Technology 56, 87-96 (2007).

144. McNamara, G. et al. Life cycle assessment of waste water treatment plants in Ireland. in East European Conference on Sustainable Development of Energy, Water and Environment Systems 14 (2014).

145. Morera, S., Corominas, L., Rigola, M., Poch, M. \& Comas, J. Using a detailed inventory 
of a large wastewater treatment plant to estimate the relative importance of construction to the overall environmental impacts. Water Res. 122, 614-623 (2017).

146. Ahn, J. H. et al. N2O emissions from activated sludge processes, 2008-2009: results of a national monitoring survey in the United States. Environ. Sci. Technol. 44, 4505-4511 (2010).

147. United States Environmental Protection Agency. Inventory of U.S. Greenhouse Gas Emissions and Sinks: 1990-2018. (2020).

148. Hospido, A., Moreira, M. T., Fernández-Couto, M. \& Feijoo, G. Environmental performance of a municipal wastewater treatment plant. Int. J. Life Cycle Assess. 9, 261271 (2004).

149. Mills, N., Pearce, P., Farrow, J., Thorpe, R. B. \& Kirkby, N. F. Environmental \&amp; economic life cycle assessment of current \&amp; future sewage sludge to energy technologies. Waste Manag. 34, 185-195 (2014).

150. Peters, G. M. \& Rowley, H. V. Environmental comparison of biosolids management systems using life cycle assessment. Environ. Sci. Technol. 43, 2674-2679 (2009).

151. Suh, Y.-J. \& Rousseaux, P. An LCA of alternative wastewater sludge treatment scenarios. Resour. Conserv. Recycl. 35, 191-200 (2002).

152. Brown, S., Beecher, N. \& Carpenter, A. Calculator tool for determining greenhouse gas emissions for biosolids processing and end use. Environ. Sci. Technol. 44, 9509-9515 (2010).

153. Alyaseri, I. \& Zhou, J. Towards better environmental performance of wastewater sludge 
treatment using endpoint approach in LCA methodology. Heliyon 3, (2017).

154. Lombardi, L., Nocita, C., Bettazzi, E., Fibbi, D. \& Carnevale, E. Environmental comparison of alternative treatments for sewage sludge: An Italian case study. Waste Manag. 69, 365-376 (2017).

155. Liu, B., Wei, Q., Zhang, B. \& Bi, J. Life cycle GHG emissions of sewage sludge treatment and disposal options in Tai Lake Watershed, China. Sci. Total Environ. 447, 361-369 (2013).

156. Shapouri, H., Duffield, J. \& Wang, M. The Energy Balance of Corn Ethanol: An Update. (2002).

157. NSF. NSF Certified Drinking Water Treatment Chemicals. NSF Certified Drinking Water Treatment Chemicals Available at: http://info.nsf.org/Certified/PwsChemicals/.

158. GAO. Energy-Water Nexus: Amount of Energy Needed to Supply, Use, and Treat Water Is Location-Specific and Can Be Reduced by Certain Technologies and Approaches. (2011).

159. Larsen, T. \& Lienert, J. NoMix-A new approach to urban water management. (2007).

160. Blume, S. \& Winker, M. Three years of operation of the urine diversion system at GTZ headquarters in Germany: User opinions and maintenance challenges. Water Sci. Technol. 64, 579-586 (2011).

161. Choe, J. K., Mehnert, M. H., Guest, J. S., Strathmann, T. J. \& Werth, C. J. Comparative assessment of the environmental sustainability of existing and emerging perchlorate treatment technologies for drinking water. Environ. Sci. Technol. 47, 4644-4652 (2013).

162. Lee, S. \& Lueptow, R. M. Reverse osmosis filtration for space mission wastewater: 
membrane properties and operating conditions. J. Memb. Sci. 182, 77-90 (2001).

163. Thörneby, L., Persson, K. \& Trägårdh, G. Treatment of Liquid Effluents from Dairy Cattle and Pigs using Reverse Osmosis. J. Agric. Eng. Res. 73, 159-170 (1999).

164. Li, X., Yan, D., An, G., Jing, D. \& Li, J. Fouling and Cleaning of Reverse Osmosis Membranes duing Municipal Tap Water Treatment on a Pilot-Scale Plant. J. Water Sustain. 1, 139-151 (2011).

165. Smith, A. L. et al. Navigating wastewater energy recovery strategies: A life cycle comparison of anaerobic membrane bioreactor and conventional treatment systems with anaerobic digestion. Environ. Sci. Technol. 48, 5972-5981 (2014).

166. EPA. Emissions \& Generation Resource Integrated Database (eGRID). (2016). Available at: https://www.epa.gov/energy/emissions-generation-resource-integrated-database-egrid.

167. Argonne National Laboratory. The Greenhouse Gases, Regulated Emissions, and Energy Use in Transportation Model. (2014).

168. NPDES. Clean Watersheds Needs Survey - 2012 Report and Data. (2012). Available at: https://www.epa.gov/cwns/clean-watersheds-needs-survey-cwns-2012-report-anddata\#access. (Accessed: 6th May 2018)

169. Kemp, W. M. et al. Eutrophication of Chesapeake Bay: Historical trends and ecological interactions. Mar. Ecol. Prog. Ser. 303, 1-29 (2005).

170. MWEA. Michigan's Wastewater Treatment Plants Recycling Metrics. (2017).

171. Agency of Natural Resources: Department of Environmental Conservation. An Analysis of the Current Status and Alternatives to Land Application. (2016). 
172. Detroit Water Sewerage Department. PC-792 Biosolids Dryer Facility. in Water Board Workshop (2013).

173. NEBRA. A National Biosolids Regulation, Quality, End Use \& Disposal Survey. (2007).

174. EPA. Biosolids Generation, Use, and Disposal in The United States. (1999).

175. The Fertilizer Institute. State of the Industry: Fertilizer Transportation. (2016). Available at: https://www.tfi.org/our-industry/state-of-industry-archive/2016/fertilizertransportation. (Accessed: 5th January 2020)

176. Google. Google Maps. 